\title{
Archeological Survey Investigations at Martin Creek Lake State Park, Rusk County, Texas
}

Timothy K. Perttula

Heritage Research Center, Stephen F. Austin State University

Bo Nelson

Heritage Research Center, Stephen F. Austin State University

Jon C. Lohse

Follow this and additional works at: https://scholarworks.sfasu.edu/ita

Part of the American Material Culture Commons, Archaeological Anthropology Commons, Environmental Studies Commons, Other American Studies Commons, Other Arts and Humanities Commons, Other History of Art, Architecture, and Archaeology Commons, and the United States History Commons

Tell us how this article helped you.

This Article is brought to you for free and open access by the Center for Regional Heritage Research at SFA ScholarWorks. It has been accepted for inclusion in Index of Texas Archaeology: Open Access Gray Literature from the Lone Star State by an authorized editor of SFA ScholarWorks. For more information, please contact cdsscholarworks@sfasu.edu. 


\section{Archeological Survey Investigations at Martin Creek Lake State Park, Rusk \\ County, Texas}

\section{Creative Commons License}

\section{(c) (1) \&}

This work is licensed under a Creative Commons Attribution-NonCommercial 4.0 International License 


\title{
Archeological Survey Investigations at Martin Creek Lake State Park, Rusk County, Texas
}

\author{
by Timothy K. Perttula, Bo Nelson, and Jon C. Lohse
}

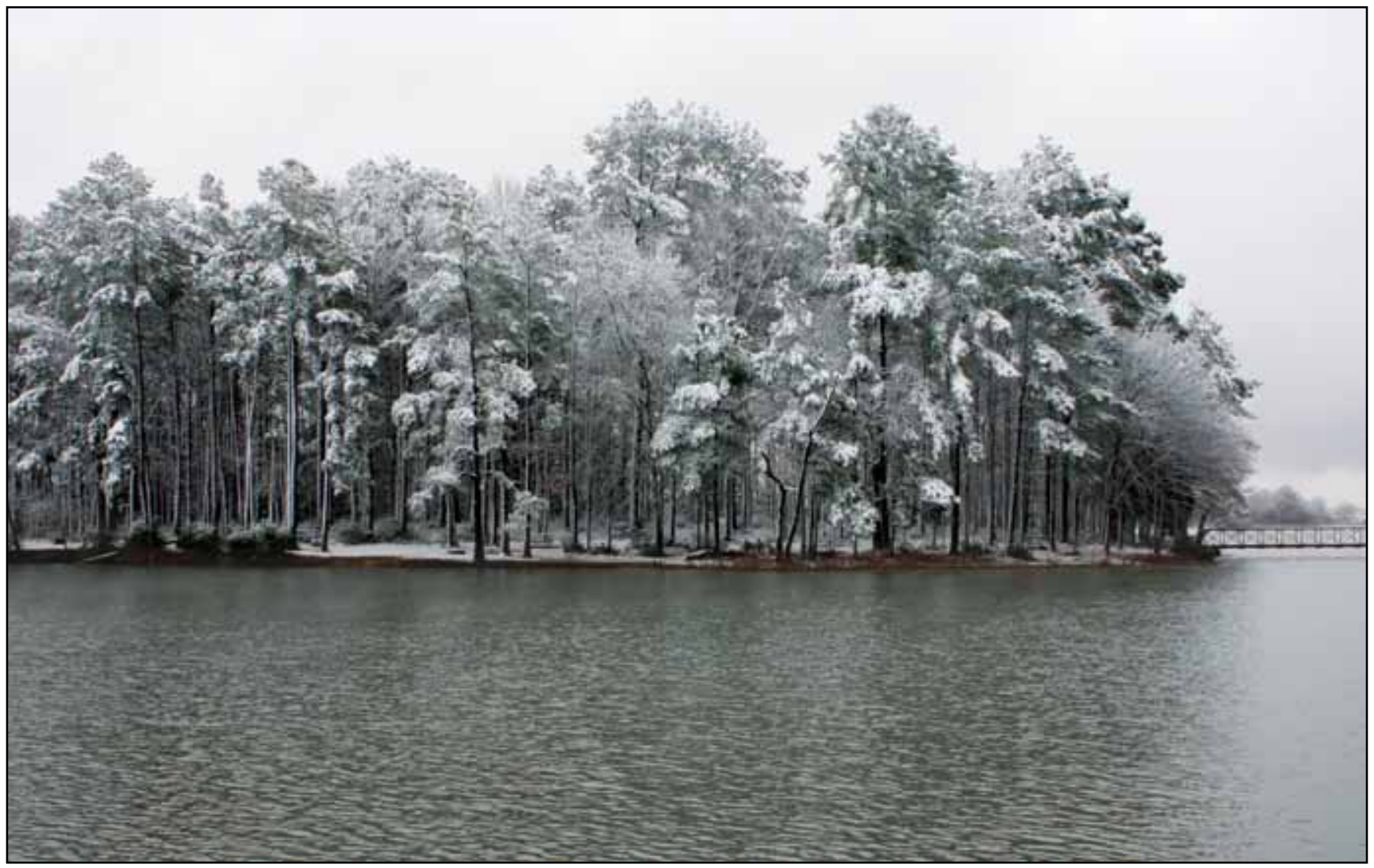

Archaeological Studies Report No. 24 


\section{Archeological Survey Investigations at Martin Creek Lake State Park, Rusk County, Texas}


Report issued in compliance with

Texas Antiquities Permit No. 5651

Jon C. Lohse, Principal Investigator 


\section{Archeological Survey Investigations at Martin Creek Lake State Park, Rusk County, Texas}

Timothy K. Perttula, Bo Nelson, and Jon C. Lohse

Archaeological Studies Report No. 24 prepared for

Texas Parks and Wildlife Department

by Center for Archaeological Studies Texas State University-San Marcos

2011 
The following information is provided in accordance with the General Rules of Practice and Procedures, Title 13, Chapter 26, Texas Administrative Code

1. Type of investigation: survey and site assessment

2. Project Name: Archeological Survey Investigations at Martin Creek Lake State Park, Rusk County, Texas

3. County: Rusk

4. Principal Investigator: Jon C. Lohse

5. Name and location of sponsoring agency: Texas Parks and Wildlife Department, 4200 Smith School Road, Austin, TX 78744

6. Published by the Center for Archaeological Studies, Texas State University-San Marcos, 601 University Drive, San Marcos, Texas 78666-4616 (2011)

Copyright (C) 2011 by Texas Parks and Wildlife Department and the Center for Archaeological Studies, Texas State University-San Marcos

All rights reserved

No part of this book may be reproduced or utilized in any form or by any means, electronic or mechanical, including photocopying, recording, or by any information storage and retrieval system without permission in writing.

For further information about this and other publications by the Center for Archaeological Studies, please contact

Center for Archaeological Studies

Texas State University-San Marcos

601 University Drive

San Marcos, Texas 78666-4616

www.txstate.edu/anthropoloy/cas

Texas State University-San Marcos is a member of the Texas State University System

copyediting and layout by Margie Elliott

Printed in the United States of America 


\section{Contents}

List of Figures $\quad$ vii

List of Tables $\quad$ ix

Acknowledgments $\quad$ xi

Management Summary $\quad$ xiii

1 Introduction 1

2 Environmental Setting 3

$\begin{array}{ll}\text { Geological Setting } & 4\end{array}$

Soils and Sediments $\quad 5$

$\begin{array}{ll}\text { Holocene Environmental Change } & 6\end{array}$

3 Culture History $\quad 9$

History of Archeological Research 99

$\begin{array}{ll}\text { Paleoindian and Archaic periods } & 10\end{array}$

$\begin{array}{ll}\text { Woodland period } & 13\end{array}$

Formative, Early, and Middle Caddo periods $\quad 16$

$\begin{array}{ll}\text { Late Caddo period } & 20\end{array}$

Historic Caddo period and Entry of Immigrant Indians $\quad 21$

Anglo-Americans, post-1830s History 24

4 Previous Investigations in the Martin Creek Lake State Park Area 27

5 Methods of Archeological Survey 29

6 Results of Archeological Survey $\quad 35$

Extent of Disturbances within the Park $\quad 35$

Shovel Test Coverage and Sediment Depth 38

Investigations at Previously Recorded Sites $\quad 41$

41RK9 41

$41 \mathrm{RK} 43 \quad 41$

41RK66, Harmony Hill Baptist Church $\quad 42$

41RK67, J. M. Robertson House 44

41RK69 46

41RK71, J. M. Griffin House $\quad 47$ 
41RK133, Henderson Road Bridge

41 RK466

41RK467, Big Toe

52

Investigations at Newly Recorded Sites

55

Site \#l (4lRK605)

Site \#2 (4 lRK606)

57

Site \#3 (41RK607)

59

Old Henderson Road (41RK608)

61

Isolated Find

7 Management Recommendations $\quad 63$

$\begin{array}{ll}\text { State Archeological Landmark Eligibility } & 63\end{array}$

Archeological Sensitivity Zones at Martin Creek Lake State Park 66

$\begin{array}{ll}\text { Management Priority Rankings } & 66\end{array}$

$\begin{array}{ll}\text { Additional Research Needs } & 69\end{array}$

$\begin{array}{ll}\text { Archival Research } & 69\end{array}$

Backhoe Investigations $\quad 69$

$\begin{array}{ll}\text { References Cited } & 71\end{array}$

Appendix 1: Previously Recorded Archeological Sites. Restricted distribution only. $\quad 91$

Appendix 2: Shovel Test Descriptions $\quad 92$

Appendix 3: Map of Site Locations at Martin Creek Lake State Park. Restricted 112 distribution only.

Appendix 4: Inventory of Artifacts from the 2010 Martin Creek Lake State Park 113 Archeological Survey 


\section{Figures}

1 Martin Creek Lake State Park project location. 1

2 Physiographic regions of Texas. 3

3 Soils within the project area. $\quad 5$

$4 \quad$ Martin Creek Lake State Park showing high (red) and moderate (blue) probability areas. 30 All other areas are low probability (in brown) Park areas.

5 Distribution of all shovel tests excavated at Martin Creek Lake State Park during the 2010 archeological survey.

6 Areas of identifiable disturbances within the boundaries of Martin Creek Lake State Park. 37

$7 \quad$ Distribution of shovel tests excavated in Martin Creek Lake State Park where the clay 39 subsoil was encountered at less than $15 \mathrm{~cm}$ bs.

8 Distribution of shovel tests excavated at Martin Creek Lake State Park where the sandy A- 40 and E-horizon sediments extend to more than $90 \mathrm{~cm}$ bs.

$9 \quad$ Map of 41RK66.

10 Profiles of 50-x-50-cm units excavated at Martin Creek Lake State Park sites. 45

11 Salt-glazed stoneware sherd from 41RK66. 46

12 Map of 41RK69.

13 Brown lead-glazed stoneware from 41RK69. Provenience, ST 321, 0-20 cm bs. 50

14 Map of the J. M. Griffin House (4lRK71). 51

15 Map of the Big Toe site (41RK467). 53

16 Hard rubber button from 41RK467. Provenience, ST 8, 0-20 cm bs. 55

17 Map of 4lRK605. 56

18 Map of 41RK606.

19 Map of 41RK607. $\quad 60$

20 Selected artifacts from 41RK607. 61

21 Areas of High Archeological Sensitivity at Martin Creek Lake State Park. 67 



\section{Tables}

$1 \quad$ Park acreage by probability area and projected intensity of survey effort. 29

2 Shovel tests excavated in the different probability areas. 29

3 Kinds of disturbances in Martin Creek Lake State Park and their spatial extent. 36

4 Depth to the clay subsoil in Martin Creek Lake State Park shovel tests. 38

$5 \quad$ Historic artifacts from 4lRK66. 44

$6 \quad$ Historic artifacts from 41RK69. 49

$7 \quad$ Historic artifacts recovered from the J. M. Griffin House (41RK71). 50

$8 \quad$ Historic artifacts from 4lRK467.

$9 \quad$ Historic artifacts from 41RK606.

$10 \quad$ Historic artifacts from 41RK607.

11 Site summaries and State Archeological Landmark determinations, Martin Creek Lake 64 State Park.

12 Management priority rankings for archeological sites in Martin Creek Lake State Park. 



\section{Acknowledgments}

We would first like to thank Texas Parks and Wildlife Department for the opportunity to conduct the archeological survey discussed in this report. Our thanks go especially to TPWD cultural resources coordinator Todd McMakin and park manager Lee Roberts. We would also like to acknowledge the efforts of the field crew-Mark Walters and Josh Hamilton-for hanging in there under trying weather conditions, and getting the archeological survey done in fine fashion. Figures in this report were prepared by Josh Hamilton, Bo Nelson, and David M. Yelacic. 



\section{Management Summary}

An intensive cultural resources survey was conducted at Martin Creek Lake State Park by the Center for Archaeological Studies and Archeological \& Environmental Consultants, LLC in June 2010 under contract with Texas Parks and Wildlife Department. Although previous investigations had been carried out in the park, no comprehensive survey had been completed that would allow TPWD and park management personnel to appropriately manage the park's cultural resources in accordance with state law. During the 2010 survey, the park was stratified into areas with high, medium, and low probability of containing archaeological sites. A total of 423 shovel tests were excavated in these areas; four new sites were documented and nine previously reported sites were revisited and assessed. These 13 sites reflect historic era occupations in the park dating from the mid-1800s to the mid-1900s and prehistoric occupations that include Late Archaic, Woodland, and Caddo components.

Based on the results of this work, together with previous findings, two sites are recommended as being eligible for designation as State Archeological Landmarks (SAL). Six sites are recommended as having undetermined eligibility for SAL status. If any of these six sites will be impacted by proposed developments within the park, further investigations are recommended in order to complete this SAL assessment. Such work should be conducted well in advance of any proposed undertaking so that TPWD archeologists can have sufficient time to complete this assessment and, if necessary, offer appropriate recommendations about how to mitigate the loss of potentially important information resulting from such undertakings.

Five of the 13 sites are not recommended as eligible for SAL status; three of these could not be relocated during the 2010 fieldwork and are thought to have been completely destroyed since they were initially recorded in the 1970s.

In addition to these 13 sites, two areas designated as having a high probability for containing additional, as-yet-undocumented deposits were identified. Future work in these areas, including use of a backhoe to reach extended depths beyond what can be achieved by shovel testing, is recommended to search for deeply buried deposits. Together, these probability areas and the management priority rankings for the 13 documented sites should allow park personnel to appropriately steward the various cultural resources that are present or that are likely to be present at Martin Creek Lake State Park. 



\section{Chapter 1}

\section{Introduction}

Martin Creek Lake State Park (Park) is located near the community of Tatum, southeast of Longview, within Rusk County, Texas, encompassing approximately 287 acres immediately adjacent to Martin Creek Lake (Figure 1). The Texas Parks and Wildlife Department (TPWD) requested a cultural resources inventory of prehistoric and historic sites located within the Park boundaries, and contracted with the Center for Archaeological Studies, Texas State University-San Marcos (CAS) to complete this work. This report presents the archeological findings from the intensive archeological survey and site evaluation project.

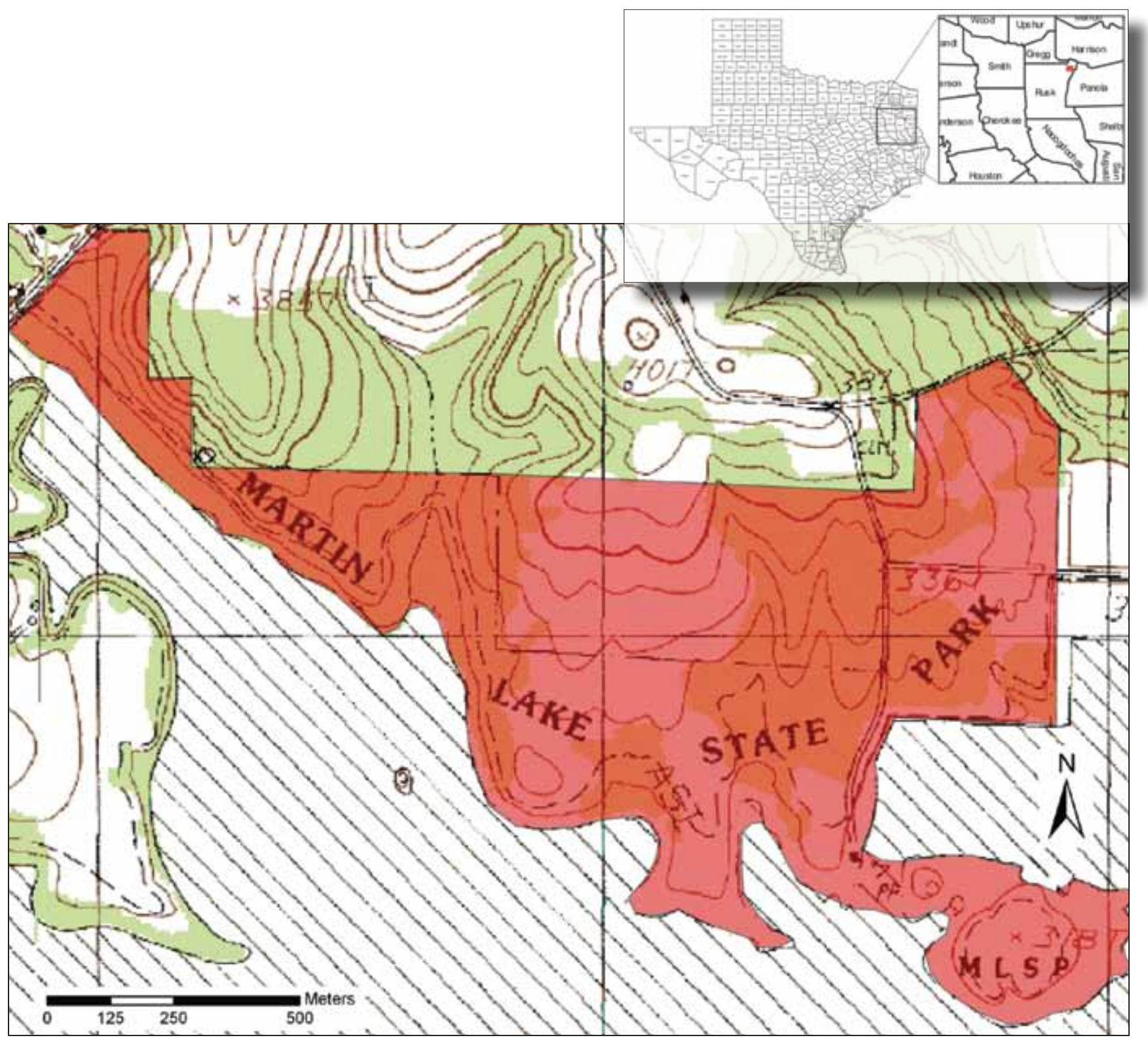

Figure 1. Martin Creek Lake State Park project location. 
In order to complete the project according to TPWD schedule considerations, CAS subcontracted parts of the project to Archeological \& Environmental Consultants, LLC (A\&E). Fieldwork was completed between June 9, 2010 and June 19, 2010. Dr. Jon Lohse (CAS) served as Principal Investigator for the project, and Rodney J. Nelson (A\&E) served as the Project Archeologist. Fieldwork was performed by Mark Walters and Josh Hamilton. Timothy K. Perttula provided significant contributions as Regional Expert. All work was done under Antiquities Permit \#5651.

The report is organized into seven chapters. Following this introductory chapter, Chapter 2 describes the environmental setting of the Park, including a review of late Holocene-era environmental change. Chapter 3 summarizes the culture history of the region, including both Native American and AngloAmerican settlements. Chapter 4 describes previous archeological research in the Park. Some of the sites identified by previous research were apparently incorrectly plotted, and the condition of many of these sites has changed since they were first recorded. Chapters 5 and 6 outline the methods employed in the current project and the results of this survey and site assessment effort. These results should be viewed by TPWD cultural resource and Park managers as the most accurate, current understanding of the Park's archeological record. Chapter 7 provides detailed discussions of the sites in terms of management priorities, including their recommended eligibility status for State Archeological Landmark designation. Site locations according to previous surveys are depicted in Appendix 1. Appendix 2 presents the results of all shovel tests excavated during this project. Appendix 3 is a map showing the current, accurate locations of all sites and their boundaries as documented in June 2010. Appendix 4 is an inventory of artifacts recovered during this project. Appendices 1 and 3 are not included in copies of this report intended for public distribution. 


\section{Chapter 2}

\section{Environmental Setting}

Martin Creek Lake State Park is located within the Pineywoods physiographic region of East Texas (Figure 2; see also Diggs et al. 2006) and is situated adjacent to Rocky Ford Creek, a small tributary of Martin Creek. Martin Creek is a major tributary of the Sabine River, with which it merges approximately $20 \mathrm{~km}$ to the east.

The Pineywoods cover large parts of East Texas and have medium-tall to tall broadleaf deciduous forests in more mesic habitats. Shortleaf and loblolly pines are common on upland fine sandy loam soils with adequate moisture. Small areas of tall grass prairie are sometimes present in both communities throughout the region (e.g., Jordan 1981:Figure 4.1), particularly in more xeric sandy lands. Bottomland communities along the major river and creek drainages contain a diverse hardwood and swamp forest (including cypress, tupelo, and sweet gum), with natural levees and alluvial terraces, point bar deposits, old stream channels, oxbow lakes, and backwater swamps. A less diverse bottomland hardwood community is present along the smaller creeks and their tributaries. The Red, Sulphur, Big Cypress, Sabine, Neches, Angelina, and Trinity rivers flow east and southeast through the Pineywoods, but none of these rivers originates in the Pineywoods.

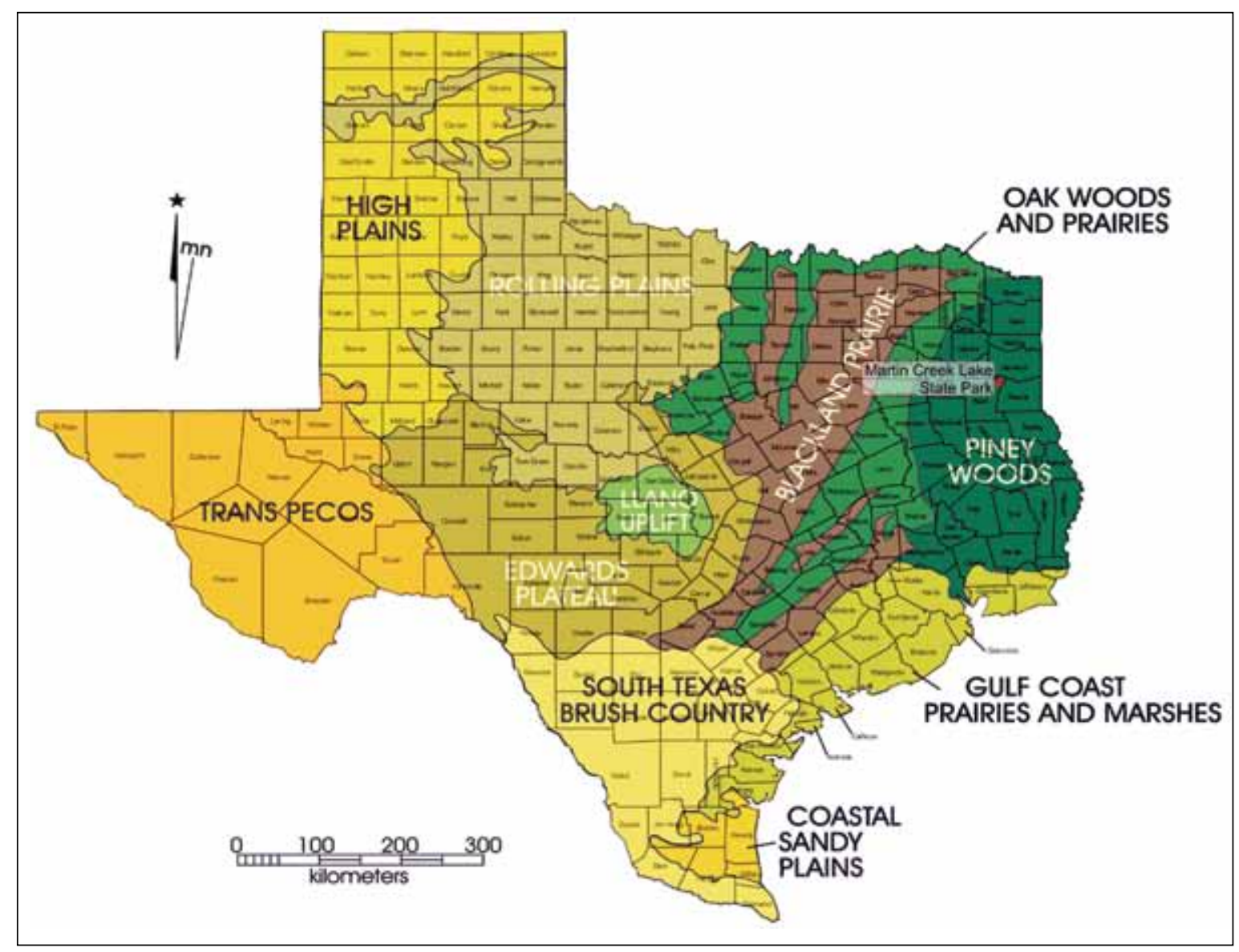

Figure 2. Physiographic regions of Texas. 
The climate of the East Texas region is humid, with a mean annual precipitation in modern times of at least 100-125 cm. Periods of maximum rainfall occur in the spring and fall. The growing season is approximately 260 days or more, with the last freeze generally occurring in March and the first freeze by late November. Droughts are not uncommon in the modern era, and dendrochronological analyses of tree rings for the last 1,000 years suggest there were numerous wet and dry spells during that time (Stahle and Cleaveland 1994, 1995), including several lengthy droughts.

Based on mid-nineteenth-century General Land Office records from various parts of East Texas, the overstory in the uplands in the Pineywoods consisted of a mixture of pine and oaks, including blue oak, blackjack oak, post oak, and red oak. This is especially the case in settings with very deep and well-drained sandy soils. Some of these landform/soil settings (probably with deep sandy sediments) in the Pineywoods probably also had pure stands of pine. In the eastern and southern parts of the region, much of the steeply sloping uplands in the Pineywoods had pines or pine-oak overstories, as southern and steeper upland slopes also would have had. However, northern and more gently sloping valley landforms appear to have been dominated by oaks.

In upland settings with thinner sandy sediments that are not as well-drained, the overstory in the Pineywoods is likely to have consisted of a variety of oaks (post oak, red oak, blackjack oak, bluejack oak, and chinquapin oak) and hickory. Abundant nut mast would have been seasonally available in these upland habitats. On landforms with deep and well-drained loamy fine sand, such as more mesic lower valley slopes, toe slopes, and elevated alluvial landforms, the vegetational overstory in the mid-nineteenth century across the region included red oak and post oak trees, along with other hardwoods that tolerate periodic flooding.

\section{Geological Setting}

East Texas is part of the Gulf Coastal Plain physiographic province. The province is composed of Mesozoic and Cenozoic sediments that filled the East Texas basin with sediments of marine, delta, and river origin, including sandstone and mudstone, along a receding coastline. These deposits dip and become progressively younger toward the present Texas coastline.

Principal geologic formations from north to south in East Texas include the Austin, Eagle Ford, Woodbine, Navarro, and Taylor groups (Cretaceous period); Wilcox and Midway groups (Paleocene period); Jackson and Claiborne groups (Eocene period); the Catahoula formation (Oligocene period); Fleming and Oakville formations (Miocene period); and the Willis formation (Pliocene period). All the major streams and most of their principal tributaries, such as Martin Creek, have Quaternary alluvium (Bureau of Economic Geology 1992). The Eocene Wilcox and Carrizo Sand formations (Bureau of Economic Geology 1965) form the underlying bedrock materials in the Park area. The Wilcox has thick fine-grained quartz sand, silty clay, and sandy clay, with beds of lignite and concretions of siltstone and ironstone (i.e., hematite and ferruginous sandstone). The Carrizo Sand is a massive quartz sand with indurated ledges of ironstone (i.e., hematite and ferruginous sandstone).

Although these geologic formations in the Gulf Coastal Plain are poor in lithic raw materials (Banks 1990:Figure 2.1), upland cobble- to pebble-sized stream gravels are relatively widespread in parts of East Texas, especially in the Trinity and Sulphur River basins (Banks 1990:56-57), and to a limited extent in the Neches River basin (see Anderson et al. 1974). However, high quality and large knappable cobbles of chert, 
novaculite, and quartzite are present only in the Red River gravels in the northeastern part of East Texas, and these are derived from chert-bearing formations in the Ouachita Mountains of southeastern Oklahoma (Banks 1990:Figure 1.20).

\section{Soils and Sediments}

As described by Griffith (2000), the soils present within the Park include Attoyac fine sandy loam, 1-3 percent slopes (AyB); Bernaldo very fine sandy loam, 1-3 percent slopes (BeB); Latex very fine sandy loam, 1-3 percent slopes (LtB); Lilbert loamy fine sand, 2-5 percent slopes (LyC); Meth fine sandy loam, 2-5 percent slopes (MtC); Naconiche mucky sandy loam, frequently flooded (Na); Tenaha loamy fine sand, 5-15 percent slopes; Woodtell loam, 1-3 percent slopes (WtB); and Woodtell loam, 5-15 percent slopes (WtE) (Figure 3). The Naconiche mucky sandy loam is present in floodplain settings, while the other soils occur in upland landforms. Generally, soil formation and its subsequent taxonomic classification depend upon a number of variable factors including climate, organisms, topography, parent material, and time.

The parent material of soils found within the Park is either alluvial (deposited by rivers or streams) or marine. These two modes of deposition are characteristic of different periods of time in the region's geomorphic history, and are reflected in distinct landforms. Older marine deposits occupy the uplands while the younger, alluvial deposits make up terrace and floodplain landforms. There are implications for archeological deposits potentially contained therein. Cultural materials deposited on flat to gently sloping

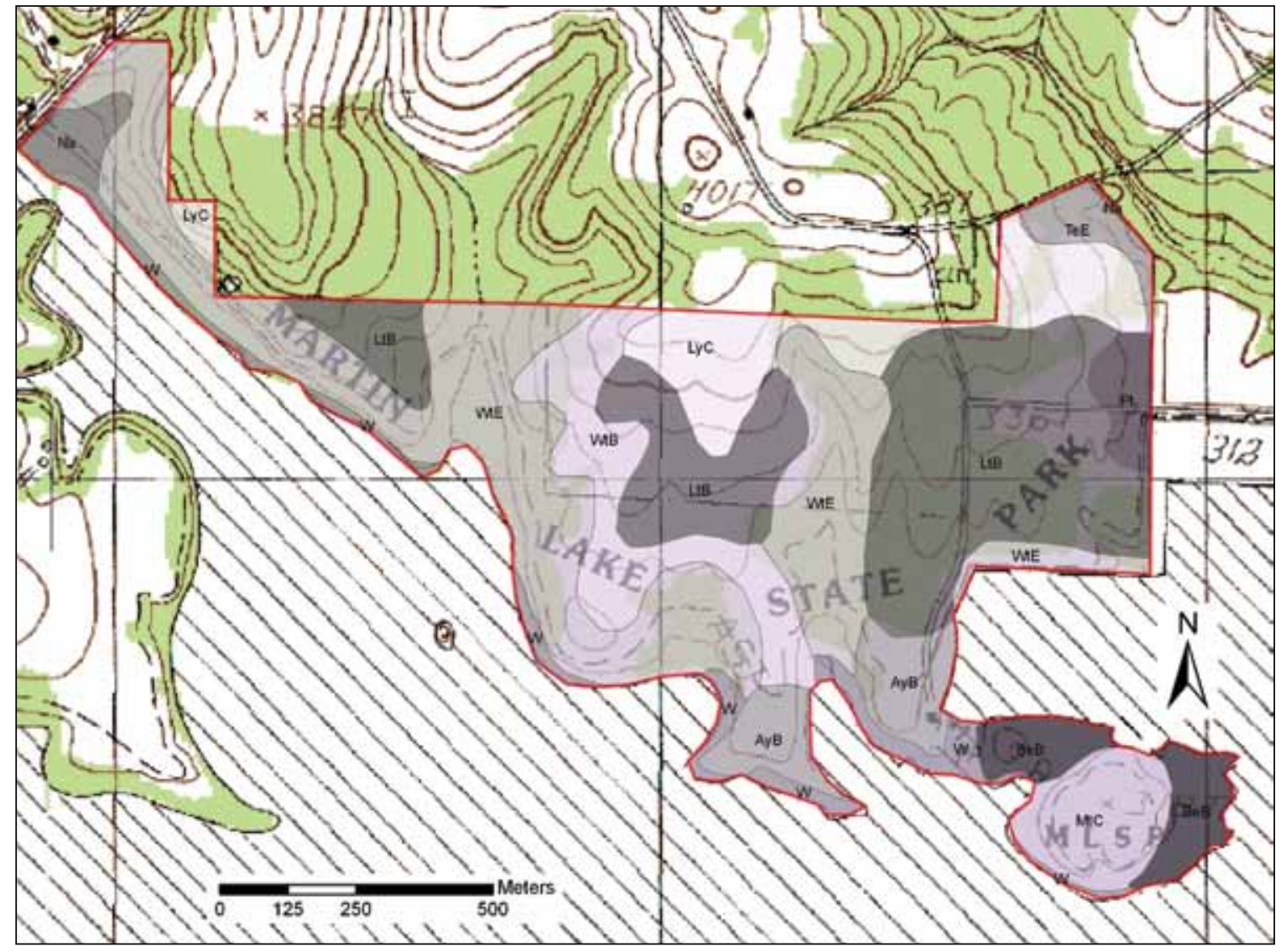

Figure 3. Soils within the project area. 
uplands would be limited to shallow contexts due to the age of the marine deposits and slow rate of aggradation. Multiple occupations of a single site would most likely be comingled and, therefore, difficult to discern. Younger alluvial sediments have the potential to contain buried archeological materials in discrete strata.

As indicated by their names, the texture of many of the soils present within the Park is sandy. These sandy sediments extend across northeast Texas, and are sometimes referred to as the Sandy Mantle when significantly thick accumulations of sandy sediments are present. The research potential of archeological sites occurring in Sandy Mantle contexts has been disputed (see Lohse and Bousman [2006:60-63] for a synopsis). Two views debate whether or not the nature of landforms (dynamic and aggrading vs. static and non-aggrading) found in East Texas Sandy Mantle areas, and the degree of translocation of archeological materials by biological mixing found in such settings, generally meet a reasonable contextual threshold for determining site integrity and contain interpretable samples of archeological materials.

\section{Holocene Environmental Change}

The climate in East Texas has changed dramatically over time. These changes have affected the biodiversity and carrying capacity of the region and in turn have likely influenced adaptations of Native American groups and later Anglo-Americans living in this region, especially as the former became more dependent upon cultivated plants and the latter more dependent on sources of water and arable soils in the risky and occasionally drought-prone environment.

Pollen data from Ferndale Bog (Holloway 1994) in the Ouachita Mountains of southeastern Oklahoma and from several bogs in Central Texas (Bousman 1998) indicate that the Late Pleistocene climate (ca. $11,000-14,000$ years ago) was cool and dry and probably supported a grassland steppe. By 11,000 years ago, as the climate became warmer and wetter, oak woodlands or oak savanna habitats would likely have been present throughout much of eastern Texas (and north into Oklahoma). These woodlands were maintained for several thousand years, perhaps until 7500 years ago, although Bousman (1998:Figure 4) notes a period of open, grassland vegetation in Central Texas at $9500-8750$ B.P. The Ferndale Bog pollen diagram (see Ferring 1994:Figure 4.5) also points to a more open and grassy setting, based on decreasing oak pollen and a lower pollen influx between approximately 8000 and 9200 years ago. Whether such a setting characterized East Texas at that time is not known.

Between approximately 7500 and 5000/4500 years ago, the Middle Holocene climate was quite warm and dry, and Ferring (1995:24) suggests this was a period of significant reduction in available biomass for Native American hunter-gatherers in the region. In the Ferndale Bog area of southeastern Oklahoma, the vegetation was an oak-hickory-pine woodland, while farther to the south and west in Central Texas, grasslands were dominant. Bousman's (1998:210) palynological analyses led him to conclude that the grass cover was greatest—and the climate the driest—between 5500 and 4500 B.P., while Ferring (1995:24) places the very dry and warm episode between approximately 6500 and 5000 B.P.

The Late Holocene period after approximately 4500 years ago appears to have been one of fluctuating climates-moist or dry cycles-that were generally wetter than during the preceding Middle Holocene period and more like modern climatic conditions. Ferring and Yates (1996:Figure 7.5) propose that there were wetter years between approximately 5000 and 2000 B.P. and after 1000 B.P., with a drier cycle 1,000- 
2,000 years ago when grassier conditions prevailed. With these climatic and rainfall conditions, oak-hickorypine woodlands were probably the principal vegetation in upland habitats in much of East Texas (as they are today), with a well-developed riverine forest in the floodplain settings.

Supporting the drier and warmer cycle in the middle portion of the Late Holocene, the Ferndale Bog pollen record indicates that the peak in pine pollen was between approximately 800 and 1800 B.P. (Holloway 1994:Table I.2), while Bousman (1998:207) notes one grass spike or peak in the Weakly Bog in Central Texas that dates about 1,500-1,600 years, with another between 400 and 500 B.P. Stable carbon and oxygen isotopes from mussel shells along Denton Creek in North Texas, however, point to a warm/dry peak at approximately 2850 B.P., and then again after 1500 B.P. (Brown 1998:164). Stable carbon isotope values from humate samples in the Cooper Lake area of the upper Sulphur River basin in Northeast Texas have C4-enriched peaks (i.e., higher C4 grasses in the biomass) around 2000 B.P. and 4000 B.P. (see Perttula 1999:Figure 2-4).

For the last 1,000 years or more, dendrochronological records (from cypress trees and logs) are the most accurate and temporally sensitive data available on Late Holocene environmental change (e.g., Stahle 1996). Fortunately, recent dendrochronological research in Texas, Arkansas, and Louisiana, as well as the Southeast and Midwest U.S., by Stahle and Cleaveland (1988, 1992, 1993, 1994, 1995) and Benson et al. (2007), has compiled significant new information on subtle but changing climatic and rainfall conditions and trends for the general Trans-Mississippi South region, of which East Texas is a part (see Schambach 2002:Figure 5.1).

Droughts have not been uncommon in the region in modern times, and dendrochronological analysis suggests there were numerous wet and dry spells between approximately A.D. 1000 and 1700, just as there were between 5,000 and 1,000 years ago. Some of the worst droughts may have occurred around A.D. 1555, 1570, 1595, and 1670, and the period of A.D. 1549-1577 has been suggested to have had the worst droughts of the past 450 years (Stahle et al. 1985), at least in parts of the mid-continent. Another severe droughty period appears to have taken place between about A.D. 1440 and 1475.

More detailed dendrochronological analyses from bald cypress tree-ring chronologies on spring rainfall between A.D. 1002 and 1988 from Big Cypress State Park in northwestern Louisiana indicate the wettest years were A.D. 1053-1057, 1168-1 176, 1178-1 180, 1265-1268, 1323-1328, 1553-1555, 1584-1586, 1718-1719, 1797-1800, 1810-1812, and 1866-1873. These years would likely have been optimal growing years for prehistoric and early historic Caddo agricultural groups, and then later for Anglo-American farmers and ranchers, assuming a correlation between crop production and spring precipitation values (cf. Anderson et al. 1995:265). The wetter rainfall conditions would also likely have led to an increase in the extent of swamp and wetland habitats in the major stream basins and a concomitant expansion in the carrying capacity of woodland plants and animals in the area. In historic times-after approximately 1650the wettest intervals occurred during 1797-1815 and 1866-1876.

Conversely, the driest years in prehistoric and early historic times in East Texas-A.D. 1014-1016, 1215-1217, 1444-1447, 1455-1460, 1529-1533, 1653-1655, 1697-1699, 1841-1846, and 1855-1860-may have led to stressed food supplies. In these instances, food stress was seen in the inability of Caddo groups and later Anglo-American settlers to produce sufficient food reserves through cultivation, including maize agriculture. The drier periods did not influence the character of Caddo settlement systems, which remained dispersed throughout the prehistoric and early historic periods, but it did influence their distribution across 
the landscape, as Caddo agricultural populations began to concentrate in the Pineywoods and along certain major streams (i.e., the Red, the lower Sulphur, the middle Sabine, and parts of the Neches-Angelina river basins).

The very dry years between A.D. 1444 and 1460 correlate well with the grass spike/drier episode noted by Bousman (1998) from the Weakly Bog pollen record. These more significant droughts probably also interrupted the flow of the numerous upland springs in the area, as well as the volume of flow in the major and minor stream basins. Reduced moisture in turn would have influenced the relative quantity of animal and plant foods in floodplain and upland forested habitats. The very droughty years during 1841-1846 correlate closely with the final abandonment of East Texas by the Caddo. Stahle and Cleaveland's (1988) drought reconstruction for North Texas indicates that three of the driest years between 1698 and 1980 occurred in 1855, 1857, and 1859, and that 1855 was the driest year in that 282-year record.

For the period of wet and dry spells from approximately A.D. 1000 to 1650 , the wetter years $(>1,400$ standard ring width indices [sri]) were more than two times as frequent as the driest and droughty $(<560$ sri) years (see Perttula 1999:Figure 2-5). After approximately A.D. 1430, the wetter years occurred less often, some 55 percent less between A.D. 1600 and 1700 than in the period of approximately A.D. 1200-1400. In historic times, the two wettest but also equitable intervals were 1792-1826 and 1861-1890, with the wetter years eight times more common than the very dry and droughty years. Conversely, during 1827-1861, the very dry and droughty years outnumbered the very wet years by a ratio of 9:1. These very different paleoenvironmental conditions over long periods of time may have played an important role in East Texas in human adaptations. These conditions may also have influenced changes to the landscape brought about by significant erosion (and the transportation of sandy sediments), stream downcutting, and the formation, preservation, or degradation of landforms that contain, or once contained, traces of human occupation. 


\section{Chapter 3}

\section{Culture History}

This section considers the diverse character of the prehistoric and Caddo archeological record in East Texas. First, the history of archeological research in East Texas is discussed, followed by a review of what is known about the prehistory and early history of East Texas, beginning with the Paleoindian period. A principal focus of the summary of Native American culture history is the post-Ca. A.D. 850 Caddo settlement of East Texas.

\section{History of Archeological Research}

Archeological research in Northeast Texas has a lengthy history that has been thoroughly discussed by several authors, particularly Story (1990), Thurmond (1990), Guy (1990), and Perttula (1992). Substantial archeological investigations began with the Philadelphia Academy of Natural Sciences expedition in 1912 along the Red River-mostly in northwestern Louisiana and southwestern Arkansas (Schambach 1983; Kelley 1997). However, Clarence B. Moore (1912) recorded several important Caddo mound sites and conducted excavations at the Moore/Higginbotham site (3MI3/30), located a few miles east of the Texas state line (Kelley and Coxe 1998; Weinstein et al. 2003).

Much of our knowledge of the prehistoric use of the region is primarily based on the 1930s excavations by The University of Texas at Austin of aboriginal sites and cemeteries (e.g., Pearce 1932; Jackson 1933, 1934) throughout the region, very notably in the upper Neches River basin, and then extensive late 1930s and early 1940s Works Progress Administration investigations at the George C. Davis, Hatchel, Mitchell, and Yarbrough sites (Guy 1990; see also Newell and Krieger 1949; Johnson 1962; Creel 1996) in Cherokee, Bowie, and Van Zandt counties, respectively. Since then, most of the information about the Paleoindian, Archaic, Woodland, and Caddo archeological record in East Texas comes from a disparate group of privately funded archeological research, including: (1) avocational archeological investigations and Texas Archeological Society field schools (see Corbin and Hart 1998; Jelks 1967; Middlebrook 1994, 1997; Perttula et al. 2001; Turner and Smith 2003), and (2) University of Texas at Austin (Fields 1979; Story 1981, 1982, 1995, 1997) and Stephen F. Austin State University field schools in archeology (see Corbin and Hart 1998). Extensive professional archeological work has also been conducted in numerous state and federally funded or permitted reservoirs in the Sabine, Sulphur, Neches, Angelina, and Big Cypress drainage basins (see Anderson et al. 1974; Bruseth and Perttula 1981; Duffield 1963; Fields et al. 1997; Jelks 1965; Jensen 1968; McClurkan et al. 1966; Thurmond 1990; Woodall 1969). Archeological survey investigations have been carried out in the National Forests in East Texas (see Sherman et al. 1999), and considerable archeological work has occurred in large surface lignite mines (e.g., Galan et al. 1997; Kotter et al. 1993; Perttula et al. 1998; Rogers et al. 2001; Sherman 2001; Rogers and Perttula 2004; Cliff and Sills 2005; Dockall et al. 2009) and in TxDOT-sponsored archeological projects (see Cliff and Perttula 2002; Cliff et al. 2004; Lohse 2005; Ricklis, ed., 2004; Rogers et al. 2003). Ahr (1999) has reported on Texas Department of Transportation investigations of a probable Late Caddo site (41CE326) exposed along the U.S. Highway 69 right-of-way, and Goode et al. (1997) have reported on investigations at the multicomponent 4lRK195. 


\section{Paleoindian and Archaic periods}

The East Texas archeological record for the period from approximately 8,000 years ago to as long as approximately 13,000 years ago (Waters and Stafford 2007), primarily consists of surficial, mixed, or isolated finds of diagnostic projectile points (cf. Bousman et al. 2004; Johnson 1989; Story 1990), based on comparisons with well-dated and stratified sites to the east and west of the region (see Anderson et al. 1996:15). At the Forrest Murphey site (41MR62), for example, Clovis, Plainview, Dalton, and other lanceolate projectile point forms and tools were found in several discrete concentrations on a high terrace above Big Cypress Creek; faunal remains from extinct elephants, a rather rare occurrence, were also recovered in apparent association (Story 1990). The Delta Bone Quarry 5 (41DT86) on the North Sulphur River contained a buried hearth and an antler tool (Slaughter and Hoover 1965), and charcoal from the hearth has calibrated intercepts ranging between 10,560 and 10,794 years B.P. (Bousman et al. 2004: Table 2.1), broadly contemporaneous with regional Folsom and Dalton complexes.

Undoubtedly other discrete archeological components are present in the region, such as the buried Finley Fan site, occupied as early as 6400 years B.P. (Gadus et al. 1992), and the spatially discrete Late Paleoindian John Pearce site in the Red River basin in northwestern Louisiana (Webb et al. 1971), but they have proven to be quite difficult to define and recognize. For example, a provocative but poorly known Paleoindian site has been reported by avocational archeologists in deep sand deposits on the Neches River, where it had been exposed by Lake Palestine shoreline erosion. Thirty-five Paleoindian lanceolates, primarily Dalton and Scottsbluff forms, projectile point preforms, drills, scrapers, and channel flakes have been found there, with most of the tools manufactured on cherts from the Edwards Plateau of Central Texas and Ouachita Mountains cherts and quartzites (Perttula 1989). The site also contains a Folsom point, two channel flakes, and a Folsom preform of Alibates agatized dolomite. In another case, McCrocklin (1994 personal communication) has documented Dalton and early side-notched Big Sandy points, knives, scrapers, bone tools (antler flakers), and cut bone (some fossilized) from blue clay deposits buried in a Red River gravel bar north of Shreveport, Louisiana. An extensive buried Early to Middle Archaic settlement is present at the Conly site along Loggy Bayou in the Red River basin in northwestern Louisiana (Girard 2000).

Paleoindian materials have been recovered at several archeological sites in the Post Oak Savanna and Pineywoods of East Texas (Bousman et al. 2004: Table 2.2 and Figures 2.45, 2.46e, h-i). The early Paleoindian (ca. 13,000-10,500 years B.P., based on calibrated dates and age estimates) archeological materials include Clovis and Folsom fluted lanceolate points, commonly manufactured on high-quality nonlocal lithic raw materials, along with scraping tools (Story 1990:Table 44). According to Bever and Meltzer (2007:Table 1), no Clovis points have been documented from Rusk County, Texas, although the overall density of Clovis points and sites is high in East Texas (Bever and Meltzer 2007:74, 17).

Unfluted lanceolates-usually resharpened and beveled-dominate the Late Paleoindian period (ca. 10,500-9500 B.P.) material culture record in the region, including Dalton (Johnson 1989:Figure 7; Wyckoff and Bartlett 1995), San Patrice, and Scottsbluff points which concentrate in Northeast Texas and locales to the east (e.g., Saunders and Allen 1997:Figure 2), as well as early side-notched points and Albany beveled bifaces or knives (see Webb et al. 1971; Johnson 1989:Figure 13), Quince-style scrapers, end and side scrapers, denticulates, burins, and bifacial adzes. San Patrice projectile points and associated tools are typically manufactured from local raw materials (Saunders and Allen 1997:3; Webb et al. 1971). 
The distributions of Paleoindian artifacts within the region suggest that these early occupations were principally situated within the valleys of major stream basins (see Thurmond 1990:Table 53 and 54; Anderson 1996a), as well as resource-rich areas like the Ouachita Mountains escarpment (Anderson 1996b:Figure 3.2). It appears that Paleoindian foraging groups occupied small camps and had an unspecialized hunting tool kit.

Anderson (1996b) postulated that the initial and most intensive Paleoindian settlement of the Southeast (which would include East Texas) took place in the resource-rich valleys of the Mississippi River and its principal tributaries. From there, Paleoindian groups settled throughout the wooded Southeast and East, with concentrations at 250-400 km intervals, indicating the scale of movement of these highly mobile foragers. The relatively sparse Paleoindian archeological record, in conjunction with the dispersion of artifacts on many landforms and different settings within the region, seems to indicate that the Paleoindian groups were very mobile hunters and gatherers rather than specialized hunters of extinct megafaunal species (Fields and Tomka 1993:82). Johnson (1989) also suggests that some of the Late Paleoindian archeological remains (Plainview and Scottsbluff projectile points, and Cody knives) from the region are a result of Plains Late Paleoindian (ca. 10,000-9,000 years ago) groups that moved into parts of East Texas during periods when grassland habitat spread eastward, in order to exploit the plains resources (such as bison) found there.

Archeological data from the Yarbrough site (4lVN6) on the upper Sabine River were employed by Johnson (1962) to first bring chronological and cultural order to the diverse Archaic (ca. 7500-500 B.C.) archeological record found in Northeast Texas. Of particular import were Johnson's (1962:208) temporal divisions of the Archaic based on projectile point sequences, and the introduction of plain ceramics at the end of the Archaic. Story (1990:Figure 32) and Thurmond (1990:Table 8) provide the most current, although still poorly dated with supporting radiocarbon assays, chronological classifications of Archaic-age dart points, with many straight and expanding stem forms characteristic of the Early and Middle Archaic periods and other straight and contracting stem darts particularly diagnostic of the Late Archaic (and much of the Woodland period as well).

Recent paleoenvironmental research (see above) suggests that much of the Archaic period, particularly the period approximately 8000-4000 years ago, was drier than today, with apparent reductions in biomass as well as the local expansion of prairie habitats along the western margins of the region. Nevertheless, drier conditions and changing vegetation conditions "clearly did not preclude occupations" (Ferring 1995:33) during these periods. While the archeological data are still rather limited, it appears that group mobility remained high for these hunting-gathering foragers (who utilized hardwood nuts, deer, shellfish, turtles, and small mammals) during the Early Archaic (ca. 9500-8000 years ago), and group territories were large and poorly defined, with most sites conforming to what Thurmond (1990:41) called "heavy" and "limited-use" areas; that is, repeated and recurrent occupations by small groups. Anderson (1996a) suggests that such Archaic groups had highly mobile foraging adaptations along the Red River, the central Sabine River, and in interior uplands away from major drainages, with expedient lithic technologies. Most sites of this age were briefly used, although this may be a product of differential site preservation, but tended to concentrate in the larger drainages within the region.

By the Middle Archaic period (ca. 8000-5000 years ago), fairly substantial and extensive occupations are recognized within the major basins in the region, with a rather limited use of smaller tributaries and headwater areas. Components of this period are open camps dominated by hunting tools (including the 
distinctive blade notched Evans point) and generalized cutting/scraping tools, lithic debris, ground stone tools, and cores.

Burned rock features (possible hearths, ovens, and cooking pits) and burned rock concentrations are present in dated Middle Archaic contexts at a few sites in the Sulphur River drainage (see Gadus et al. 1992; Cliff et al. 1996), suggesting that an important activity was the cooking and processing of plant foods, but mainly by small groups for short-term use (Fields et al. 1997:90). A single burned rock feature at the Unionville site (41CS151) has a calibrated date of 4040-4161 B.C. (Cliff et al. 1996). Lithic raw material data from a possible Middle Archaic assemblage at Lake Fork Reservoir in the upper Sabine River basin indicates that the exchange of nonlocal materials (particularly finished tools) was commonplace (Perttula 1984), although "patterns in raw material use were not uniform across Northeast Texas" (Fields and Tomka 1993:92), and in general the use of nonlocal raw materials was not common. At Cooper Lake in Archaic contexts, the nonlocal lithics that are present primarily originated to the north in the Red River basin (Fields et al. 1997). Mound complexes of Middle Archaic age in northern Louisiana at this time also suggest the development of more complex hunter-gatherer societies in the Trans-Mississippi South (see Saunders et al. 1997; Saunders and Allen 1997).

Late Archaic sites (ca. 5000-2500 years B.P.) are widely distributed in the Pineywoods and Post Oak Savanna, occurring along the major streams, near springs, on spring-fed branches, upland ridges, and on tributary drainages of all sizes. In fact, the distribution of Late Archaic sites suggests these groups moderately to extensively ranged over and exploited almost every part of the region. In particular, Anderson (1996a) has noted major concentrations of Late Archaic sites along the Red and Little Rivers in southwest Arkansas and northwest Louisiana, as well as in the Ouachita Mountains. Aboriginal populations continued a generalized foraging adaptation, combined with apparent population growth. There are only a few well-dated Late Archaic period components known in the region, however.

Some Late Archaic occupations in riverine settings contain earthen middens (i.e., the Yarbrough site along the Sabine River), but, generally, sites of this age contain burned rock features and/or concentrations of burned rocks as well as small pits. The Late Archaic occupation in Area C at the Unionville site (41CS151) had a buried anthrosol or occupational surface that had been darkened or stained by cultural activities, while within the anthrosol were two clusters of burned rock features (Cliff et al. 1996). Large pits and rock hearths in a Late Archaic component at the Herman Bellew site (41RK222) have calibrated dates that range from 380 to 1590 B.C. (Rogers et al. 2001). At the Mockingbird site (41TT550) in the Big Cypress Creek drainage, the Late Archaic component (dated 410-830 B.C.) contained scattered burned rocks and low frequencies of stone tools and projectile points, suggesting it was used only as a temporary encampment or "limited use" area. Many other Late Archaic sites or components are known where burned rocks from hearth construction and use were relatively abundant, along with projectile points, bifacial and flake tools, and flake debris. In cases of extensive occurrence of burned rock features, this suggests that the cooking and bulk processing of plant foods in ovens and pits was important to some Late Archaic populations in the region.

These settlement data are compatible with higher population densities, limited group mobility but a wide dispersion of camp and foraging areas, the possible establishment of definable territorial ranges, and a well-developed foraging economy based on the hunting and gathering of local food resources. No paleobotanical evidence is available that indicates the Late Archaic populations here cultivated native plant 
species (i.e., such as sumpweed, sunflower, and chenopod), as was the case by the first millennium B.C. in many parts of Eastern North America (Fritz 1994:25-27). Nutshells and a few fragments of prairie turnip (Psoralea sp.) are documented in Late Archaic components at the Unionville site (Cliff et al. 1996) along the lower Sulphur River, and at Cooper Reservoir sites (Fields et al. 1997). The high use of local lithic raw materials during the Late Archaic speaks to a more confined interregional interaction at this time (Fields and Tomka 1993; Perttula and Bruseth 1995). By contrast, in the Mississippi River basin of northern Louisiana, Late Archaic sites are marked by extensive quantities of nonlocal lithic raw materials, particularly novaculite and Ozark cherts (Saunders and Allen 1997:19)

\section{Woodland period}

The Woodland period (ca. 500 B.C. to ca. A.D. 800-850) in much of the region, particularly from the Sabine and Sulphur rivers to the Red River, may be recognized primarily by plain and relatively thick ceramic bowls and "flowerpot-"shaped jars, double-bitted axe heads, the smaller and thinner Gary projectile points, and later in the period by corner-notched arrow points (Schambach 1998, 2001; Thurmond 1990). North of the Sulphur River and in contiguous areas in southwestern Arkansas, northwestern Louisiana, and southeastern Oklahoma, such Woodland cultures have been called Fourche Maline by Schambach (1998, 2001).

In several instances, Lower Mississippi Valley (LMV) related ceramics (such as Tchefuncte Stamped, Churupa Incised, Marksville Incised, Troyville Stamped, and Marksville Stamped) occur with some frequency in Woodland period components (Story 1990:246; Rogers et al. 2001). These ceramics may be trade items that evidence contact and interaction between Trans-Mississippi South Native Americans and groups in the LMV, or were ceramics whose stylistic decorative attributes were borrowed by local potters (see Schambach 1982, 1998; Perttula and Bruseth 1995).

At Woodland period sites along the Red River in southwestern Arkansas and Northeast Texas, ceramics used for cooking and food serving are abundant, and make up a significant proportion of the artifact assemblages, while in many other Woodland period sites in much of Northeast Texas (particularly between the Sulphur and Sabine rivers, but also characteristic of Woodland period sites in the Neches/Angelina river basins), the use of ceramics was not as prevalent. These variations in the frequency of occurrence of ceramics suggest regional differences in Woodland period food processing (i.e., boiling of foods in vessels to make them palatable and a change from stone to wooden food preparation tools) and dietary habits (i.e., an increased consumption of carbohydrate-rich foods, possibly including some amounts of maize). It is probable that there were also differences in sedentism between Woodland populations across the region, based on strong correlations between sedentism and pottery making.

Later LMV Coles Creek period ceramics (and expanding stem arrow points similar to the Colbert and Friley types) are present in notable quantities in several sites along the Sabine River and the Red River, particularly at James Pace in a context dated approximately 1300-1000 years B.P. (Girard 1994), and at the generally contemporaneous Ray site (4lLR135) (Bruseth 1998). Similar ceramics occur in stratified contexts at the Crenshaw (3MI6) and Mounds Plantation (16CD12) sites in burial mound features (Schambach 1997; Webb and McKinney 1975). This is also the period when larger villages and multiple mound centers begin to be constructed on the major streams (i.e., the Red and Sabine rivers) in the Trans-Mississippi South. 
To the south of the Sabine River, but concentrated in the Neches-Angelina and Attoyac drainage basins, Woodland period sites contain plain sandy paste ceramics (Goose Creek Plain, var. unspecified) of the Mossy Grove tradition (Story 1990:Figure 39; Ricklis 2004: Figure 6.7) as well as decorated ceramics with LMV affiliations. Woodland period components account for at least 25-50 percent of the known prehistoric archeological sites in the Angelina-Neches confluence area and points west (Martin et al. 1995:Table 2; Perttula et al. 1993) and represent the campsites and habitation locales of seasonal foraging-gathering and hunting adaptations. Aboriginal pottery was adopted and used by Mossy Grove groups for the cooking and processing of plant and animal foods by about 2,000 years ago, and by A.D. 600/700, if not earlier, the Mossy Grove populations were using a variety of stemmed arrow points for hunting.

Changes in the density and placement of Woodland period sites across the landscape-particularly focusing on sandy interfluves-led Corbin (1998:114-115) to suggest that horticulture may have been introduced in the Neches-Angelina river basins during the Woodland period. Another alternative posited by Corbin (1998:115) to account for the number and distribution of Woodland period sites in that part of East Texas may "have been tied to ... moving closer to a significant plant food source (i.e., plants that were restricted to valley margins and/or the floodplain) whose use was facilitated by processing via cooking in ceramic vessels." Settlement data from the McGee Bend area at the confluence of the Angelina and Attoyac rivers indicates that middens and occupational components are present in Woodland period contexts that range in size from 0.5 to 8 acres (Duffield 1963; Jelks 1965).

Woodland period groups were still primarily hunter-gatherers who lived in increasingly larger groups and resided for longer periods of time at some sites. The fact that some of these latter sites have relatively substantial midden deposits (particularly along the Red River and in the upper Sulphur River basin, see Schambach 1982; Fields et al. 1997), and some evidence for structures (probably daubed pole-and-thatch structures), suggest more intensive occupations, decreased residential mobility, and higher population densities, but the degree of permanence is still less than that seen in the subsequent long-term Caddo settlement of East Texas (Perttula et al. 1993:99). Schambach (1983:5) has suggested that Woodland (or Fourche Maline) period settlements along the Great Bend of the Red River included "small to medium sized villages of from 1 to 4 ha."

On the basis of the available paleobotanical information, Woodland period groups may have cultivated squash (see McGregor 1997), and used native seeds and tubers/roots, as well as a variety of woodland and aquatic animal resources, particularly white-tailed deer. At the Resch site, the rather extensive midden deposits contained only burned rock features (probably used for the cooking and baking of plant foods) and dense quantities of charred nutshells and poorly preserved animal bones (Webb et al. 1969). The presence of chipped stone axes and hoe-shaped tools in Woodland occupations suggest that some horticultural practices (perhaps the use of colonizing weedy annuals) and forest clearance may have begun. Stable isotope analyses of human remains of some 25+ Late Archaic, Fourche Maline, and Formative-Early Caddo period samples indicate that maize was not a major part of the diet of Woodland period groups (see Rose et al. 1998). The examination of skeletal pathologies in Woodland period contexts from the Red River area and East Texas indicates low levels of infection, but high levels of degenerative diseases relative to subsequent Caddo populations (Rose et al. 1998:Table 6-4). These data further support the idea that Woodland period populations were primarily hunter-gatherers with a nutritionally adequate diet, who probably lived across the region in relatively low population densities, but whose lifestyle was 
characterized by chronic stress (on the joints) and heavy work loads (Rose et al. 1998:121). Maize is also poorly represented in the archeological record before approximately A.D. 700-900.

In much of East Texas, Woodland period sites are not very common, perhaps because most of the area was not heavily settled during this time (e.g., Story 1990:310). One of the few well-studied Woodland period components in the Sabine River drainage is at the Herman Bellew site (41RK222), where the component dates between approximately 500 B.C. and A.D. 685 (Rogers et al. 2001), and had rock concentrations as well as small and large pits, contracting stemmed dart points, and a small amount of mainly plain ceramics as well as LMV ceramic sherds. By contrast, settlements of this period are common throughout the Sulphur (see Fields et al. 1997) and Neches-Angelina river basins (Corbin 1998).

No Woodland period burial mounds have been documented north of the Sabine River in the Pineywoods and Post Oak Savanna, although they have been found in blufftop and alluvial valley settings on the Red River in northwestern Louisiana and southwestern Arkansas (Schambach 1982, 1997; Webb 1984), and on the Angelina, Neches, and Sabine rivers in deep East Texas (Story 1990:310; see also Jelks 1965 and Jensen 1968). Associated with the construction and use of mounds in the Woodland period was the procurement and dispersal of costly nonlocal raw materials and artifacts, including cherts, copper, and LMV ceramic vessels that were included as grave goods or caches in the burial mounds.

The two or three mounds at James Pace (16DS268) on the Sabine River, however, apparently did not serve as platforms for burials or structures or as caps for these features, and their functional significance is undetermined (Girard 1994:15). The appearance of burial mounds (and mounds covering crematoria) in the broader region does suggest that more complexly organized local groups did develop during the Woodland period in these localities (cf. Schambach 1996, 1997).

In non-mound contexts, there is also evidence of mortuary or ritual practices in the Woodland period. The Hurricane Hill site on the South Sulphur river contained a small cemetery on a prominent hill that dates between cal A.D. 59 and 449 (Perttula 1999), and the Mahaffey site on the Kiamichi River in southeastern Oklahoma also had a large cemetery with flexed and semi-flexed burials without grave goods (Perino and Bennett 1978). Later Woodland period cemeteries with 9-21+ burials-dating after approximately A.D. 200-500-have also been identified at sites such as Snipes (41CP8; Jelks 1961) in the lower Sulphur River basin, and several sites in southwestern Arkansas (Schambach 1982). These later shallow extended burials contained an occasional whole vessel, boatstone, celt, or chipped biface. The vessels include flowerpotshaped Williams Plain and Coles Creek Incised types (see Jelks 1961:Plate 4). The Crenshaw site also had many late Woodland period extended burials in village midden contexts (the large village is estimated to cover $8 \mathrm{ha}$ ), and these also contained ceramic vessels as funerary objects (Schambach 1982:152).

Comparable burial cremation practices at the Hurricane Hill site in the upper Sulphur River basin and the contemporaneous Johnny Ford site (3LA5), an early Fourche Maline village (ca. 200 B.C.-A.D. 300) in the Great Bend area of the Red River valley, suggests the existence of similar belief systems among aboriginal Woodland period groups in the Red and Sulphur river basins. Schambach (1996:36) describes the burials at Johnny Ford as occurring in a "cremation cemetery," and he further suggests that everyone in the village may have been cremated (adults and children were also cremated at Hurricane Hill), using bluff-edge crematoria at mound sites (Schambach 1997:57).

The identification of formally bounded cemeteries at a number of Woodland period habitation sites 
in the Trans-Mississippi South (see Rose et al. 1999) is consistent with the existence and settlement of distinctive social groups (based on kinship and/or residence) of affiliated individuals at sites and various locales during that time. It appears that children and adults were buried together in these cemeteries, suggesting that these Woodland populations had an egalitarian social organization within local settlements and communities. At its broadest scope, the establishment of cemeteries clearly correlates with an increasing sedentism in the western Gulf Coastal Plain of East Texas after approximately 200 B.C.

\section{Formative, Early, and Middle Caddo periods}

Abundant archeological information is available on the Formative (ca. A.D. 800/850-1000), Early (ca. A.D. 1000-1200), and Middle (ca. A.D. 1200-1400) Caddo period occupation of the Pineywoods and Post Oak Savanna of East Texas. First, Caddo archeological sites of these ages are quite common, and about 80 percent of the 500+ radiocarbon dates available from Northeast Texas archeological sites pertain to occupations at prehistoric and protohistoric Caddo sites. The largest number of dates fall in the Middle Caddo period (ca. A.D. 1200-1400), followed by the Early Caddo period (ca. A.D. 1000-1200). Using calibrated ages and age mid-points of 1-sigma calibrated age ranges, the largest number of Caddo radiocarbon dates fall within the AD 1201-1300 interval (Perttula 1998). While the number of dates in this period is probably inflated to some degree by the extensive series of dates from the George C. Davis site (see Story 1997, 2000), it does appear to be the case that Middle Caddo period occupations are rather commonplace throughout much of East Texas (Middlebrook and Perttula 1997), supporting the broad findings of the radiocarbon dates from the region.

Caddo sites of Formative to Middle Caddo period age are situated primarily on elevated landforms (alluvial terraces and rises, natural levees, and upland edges) adjacent to the major streams, as well as along minor tributaries and spring-fed branches. Proximity to arable sandy loam soils was preferred for settlement locations, presumably because of good drainage for habitation and for cultivation purposes. The majority of these Caddo sites are permanent settlements where posts, pits, and other features provide evidence of structures. Cemeteries and graves where the dead were buried are present, as are middens containing animal and plant food refuse along with broken stone tools and pottery vessels. Material remains of tools and ceramics signify usage in the procurement and processing of the bountiful resources of the region. These sites represent the settlements of Caddo communities and sociopolitical entities, and the civic-ceremonial centers that were their focus (Perttula 1993:125).

The distribution of Caddo settlements across the landscape suggests that all habitats were used to some extent, either intensively as locations for the sedentary communities and farmsteads (that may have been occupied for single or multiple generations), or periodically by groups in logistical camps where specific natural resources could be procured in bulk. Along the Red River, and probably on the other large streams or rivers in the region, a particular focus of settlement was along natural levees in recently abandoned meander belts, and these habitats "served as an ideal context for a dispersed community" in a major floodplain landscape (Girard 1997:156).

The most common types of Caddo settlements in the region during these times appear to have been small year-round hamlets and farmsteads with circular to rectangular structures (Clark and Ivey 1974; Bruseth 1998; Bruseth and Perttula 1981; Cliff 1997; Middlebrook 1994, 1997; Perttula and Nelson 2003; 
Rogers and Perttula 2004; Thurmond 1990). These settlements sometimes occur in association with small household cemeteries (see Goldschmidt 1935; Middlebrook and Perttula 1997), and occasionally with a larger cemetery (> 10 burials).

Larger communities (covering more than 10 acres) have also been recognized that occur in association with mound centers (such as the large settlements at George C. Davis [41CE19], Hale [41TT12], Boxed Springs [41UR30], and Hudnall-Pirtle [41RK4; see Bruseth 1991; Bruseth and Perttula 2006]). These mound centers have extensive habitation areas, plazas, and spatially restricted temple and burial mound locales. Shaft burials of high-status individuals have been documented in mound contexts at the George C. Davis site (Story 1997, 1998, 2000) and a few other mound centers (such as Washington Square [41NA49)], Boxed Springs, and Sanders [4lLR2]; see Corbin and Hart 1998; Hamilton 1997), and they also occur in non-mound contexts at several sites along the Red River during Formative period (see Bruseth 1998).

Certainly the most thoroughly studied Formative and Early Caddo period site in the region is the George C. Davis site, a large village and mound center on the Neches River. Recent investigations using remote sensing indicate more than 100 structures in the village areas around the three mounds at the site (Creel et al. 2005; Walker 2009). Calibrated radiocarbon dates from village contexts establish that the site was occupied beginning by the mid-ninth century A.D., and that it was continuously settled to the end of the thirteenth century A.D. (Story 2000). A large number of structures were built on and adjacent to Mound $\mathrm{A}$, and the extensive structure rebuilding there indicates the area was preferred for settlement by the Caddo. Calibrated dates from a few contexts suggest that the site was inhabited to some degree as late as approximately A.D. 1350 (see Story 1997). There were three mounds at the Davis site, including Mound A (a flat-topped platform), Mound C (burial mound) built over a large pre-mound burial pit in the latter part of the Formative Caddo period and containing an estimated 25-30 elite burial pits, and Mound B (a second flat-topped platform) constructed about A.D. 1200 or slightly earlier (Story 1997, 1998).

One of the more significant non-mound Caddo sites investigated in the Pineywoods, the Oak Hill Village (41RK214), estimated to date approximately A.D. 1150-1450, contains at least 42 circular and rectangular structures. Some of the structures had been rebuilt and some overlapped earlier structures, particularly at the northwestern end of the ridge and plaza, and they were arranged over the 3.5-acre village in a circular pattern around a central plaza area (Rogers and Perttula 2004; Perttula and Rogers 2007). Several small structures on the eastern side of the plaza have been identified as possible granaries for the storage of harvested corn. A small mound (covering a burned circular structure) is at the north end of the site, and several midden deposits have been identified that appear to be associated with individual structures. Two large circular structures have extended entranceways that pointed towards the plaza, and their special form and orientation suggests that they were probably public buildings used by the Oak Hill Village community for special purposes. Ceramic analyses and radiocarbon dating indicate these structures were built after approximately A.D. 1350 during the extensive Late Village (Rogers and Perttula 2004; Perttula and Rogers 2007).

The Musgano site (4lRK19) is also a Middle Caddo habitation site that was located on an upland landform not far from Martin Creek, and is now an island in Martin Creek Lake. This site covered approximately five acres and had at least one circular structure, midden deposits, numerous pits (including two with charred corncobs), and an extensive ceramic and faunal assemblage (Clark and Ivey 1974). One area of features to the east of the one excavated circular structure appears to mark an above-ground 
granary (built on stilts), with smoky fire pits under it. (The feature was filled with charred corncobs, which would have produced a large amount of smoke when set on fire.)

Another important site of the Middle Caddo period is Tyson (41SY92), located in the Attoyac River basin, dated cal A.D. 1336-1490. This settlement contains evidence for structures and cooking and storage pit features, contains extensive midden deposits and well-preserved plant and animal remains, and a small cemetery of children. Middlebrook $(1994,1997)$ suggests that the Tyson site represents the residence of a caddi or chiefly elite.

One of the calibrated dates from the Tyson site was from mussel shell included as grave goods with Feature 14, the burial of a 3- to 4-yr-old child accompanied by many grave goods (Middlebrook 1994:16). Among the burial offerings were eight ceramic vessels near the head and feet of the child, two large paired deer antlers over the child's head (perhaps as part of a headdress), carved shell inlays near the head, two carved bone ear spools, 32 olivella shell beads, three columnella beads from a necklace, a turtle rattle, a cache of mussel shell, smoothed stones, two pitted stones, a cache of six deer ulna awls and two beaver teeth, and a cache of lithic pebble cores, flakes, preforms, and a notched shell point (Middlebrook 1994:16).

These groups from the Formative through Middle Caddo periods seem to have been horticulturists, cultivating maize and squash, along with several kinds of native seeds (Perttula and Bruseth 1983). They gathered nuts and roots and tubers that could be stored and were proficient hunters of deer, fish, and many other animal species. The available paleobotanical and bioarcheological evidence (including stable carbon isotopes on human remains) from East Texas (and elsewhere in the Caddo archeological area, including the upper Neches River basin; see Rose et al. 1998) does not indicate however that Caddo groups became dependent upon maize and other domesticated crops until after about A.D. 1300. By approximately A.D. 1450, maize likely made up more than 50 percent of the diet (see Burnett 1990; Perttula 1996; Rose et al. 1998). Certain prehistoric groups who lived in the Trinity River basin in north central and east central Texas (outside of East Texas) and who interacted with the Caddo living in the Neches River basin, also cultivated plants, but these plants appear "to have been incorporated into an existing subsistence system at a supplemental level...growing of crops...simply offered another source of foodstuffs" (Gadus et al. 2002:141).

Both temple and burial mounds were built by these Pineywoods Caddo groups. The larger sites are important civic-ceremonial centers containing multiple mounds and associated villages, and these generally date after approximately A.D. 900. The multiple mound centers are rather evenly spaced along the Red River, Sabine River, and Big Cypress Bayou, and those that are contemporaneous may represent hierarchical systems of an "integrated ... regional network of interaction and redistribution" (Thurmond 1990:234). The Jamestown (eight mounds and village), Boxed Springs (four mounds, village, and large cemetery), and Hudnall-Pirtle (eight mounds and 60-acre village) multiple mound centers appear to represent the apex of postulated local Early-Middle Caddoan networks in the Sabine River basin. The McKenzie (4lWD55) site in the middle Sabine River drainage has a single substructural mound that dates cal A.D. 1298-1470 (see Granberry 1995), and there are contemporaneous mounds covering structures with extended entranceways at the Redwine (41SM193) and Bryan Hardy (41SM55) sites (see Walters et al. 1998; Walters and Haskins 2000). The Middle Caddo occupation at Redwine also included an extensive midden deposit, hearth and pit features and a small cemetery with extended supine burials.

The distribution, number, and spacing of mound centers, particularly the sites with multiple mounds, in East Texas and adjoining parts of southwestern Arkansas and northwestern Louisiana attest that the Caddo 
peoples who built and used these mounds were integrated into societies of considerable sociopolitical complexity. The premier mound centers in the Neches-Angelina river basins include George C. Davis and Washington Square (Story 1997; Corbin and Hart 1998). The Washington Square mound complex is welldated, with pooled radiocarbon dates on charcoal, hardwood nutshells, and charred corn ranging between cal AD 1268 and 1302 (Corbin and Hart 1998:74 and Table 4); the overall range of the calibrated dates from the site suggest it was occupied by the Caddo between approximately A.D. 1250 and 1450. Extensive excavations documented a circular structure under Mound 1/2, an assortment of pits and postholes in non-mound contexts, and several large burial pits in a mortuary mound (the Reavely-House Mound). No clear evidence for on-site permanent Caddo habitation was identified at Washington Square, although an interesting assortment of large sherd-filled pits (representing many vessels) were encountered in one area between Mound 1/2 and the mortuary mound (see Corbin and Hart 1998:Figure 14). These may represent deposits from public feasting activities led by the Caddo elite (e.g., Scott and Jackson 1998) who used the Washington Square mound site as a ceremonial center in the thirteenth and fourteenth centuries.

The radiocarbon dating of the Washington Square and George C. Davis sites hints at the possibility that the Washington Square Mound center began to flourish about the time (after ca. A.D. 1250) the George C. Davis site was diminishing in power and social authority. These temporally coincident occurrences suggest that the Caddo community who built and used the Washington Square Mound site-more advantageously located eastward at the nexus of aboriginal trails running north-south (later to be known as the Caddo trace) and east-west (later known as the Camino Real)_achieved preeminence at the expense of the long-lasting polity on the Neches River. The George C. Davis site was abandoned by the early fourteenth century.

The Formative, Early, and Middle Caddo period groups possessed a rich material culture. Well-made, corner-notched, and rectangular-stemmed arrow points were common, along with siltstone and greenstone celts, perforators and borers, large Gahagan bifaces, and a variety of more expedient stone tools (unifacial flake scraping and cutting implements). Long-stemmed Red River (Hoffman 1967) and cigar-shaped ceramic pipes were made by the Caddo at this time, as were ceramic ear spools and figurines (see Newell and Krieger 1949).

The most distinctive material culture item of the Caddo groups living in East Texas were the ceramics made as cooking, storage, and serving vessels. The styles and forms of ceramics found on sites in the region hint at the variety, temporal span, and geographic extent of a number of prehistoric Caddo groups spread across the landscape. The diversity in decoration and shape in Caddo ceramics is substantial, both in the utility-ware jars and bowls, and in the fine ware bottles, carinated bowls, and compound vessels. This diverse and distinctive ceramic assemblage characterizes the Caddo ceramics throughout the region, occurring quite commonly in domestic contexts on habitation sites as well as in mortuary contexts where they appear as grave goods.

The Caddo made ceramics in a wide variety of vessel shapes, with many well-executed body and rim designs and surface treatments. An impressive diversity of vessel forms are present among the Caddo fine wares, including carinated bowls, deep compound bowls, double and triple vessels (joined bowls and bottles [Suhm and Jelks 1962:Plates 38k, 5le, 59d]), bottles, ollas, zoomorphic and anthropomorphic effigy bowls and bottles, ladles, platters, peaked jars, gourd and box-shaped bowls, and chalices. Based on the archeological contexts in which they have been found and inferences about their manufacture and use, it is evident that ceramics were important to the prehistoric Caddo as functional items in which foods were 
cooked, served and stored and as personal possessions, for their beauty as works of art and craftsmanship (i.e., some vessels were clearly made never to be used in domestic contexts). In some cases, ceramics probably functioned as social identifiers, with certain shared and distinctive stylistic motifs and decorative patterns marking closely related communities and constituent groups.

The Caddo produced fine wares (with very finely crushed temper) shaped into bottles and many different bowl forms as well as utility wares (simple bowl forms and jars of various sizes). Almost all Caddo ceramics were tempered with grog (crushed sherds) or bone, although burned and crushed shells were used as temper after approximately A.D. 1300 among most of the Red River Caddo groups and later at sites in the lower and upper Sulphur River basin. Grog-tempered pottery was the norm throughout most of the Sabine River basin. After adding the temper to the clay, the kneaded clay was formed into clay coils that were added to flat disk bases to form the vessel, and the coils were apparently smoothed with a round river pebble to create the finished vessel form. Decorations and slips were added either before or after baking in an open fire. Vessels were then commonly burnished and polished. Red ochre and white kaolinite clay pigments were often added to or smeared onto the decorations on bottles and carinated bowls. Ceramics were designed to serve different functions within Caddo communities and family groups-from everyday cooking pot to ceremonial mortuary beaker-and the differences are reflected in differences in paste, surface treatment, firing methods, decoration, and vessel form that distinguished fine wares and utility wares.

Other types of ceramic artifacts manufactured by prehistoric Caddo groups include ceramic ear spools and disks, figurines, and various pipe forms (Jackson 1933:71). The earliest types of Caddo clay pipes were plain, tubular and cigar-shaped forms, followed by the long-stem "Red River" pipes (Hoffman 1967) with burnished and polished stems and bowls; rectangular platform pipes and some elbow pipe forms have also been recovered in Caddo sites dating before A.D. 1200 (see Bruseth and Perttula 1981; Rogers and Perttula 2004:Figure 120). The later Caddo pipe forms in Northeast Texas are biconical and elbow pipe forms with small bowls $(<25 \mathrm{~mm}$ ) and small stem diameters (<25 mm) (see Jackson 1933:Plates 16-18).

\section{Late Caddo period}

Late Caddo period settlements (ca. A.D. 1400-1680) in much of the Pineywoods and Post Oak Savanna of East Texas have been termed rural Caddo community systems (Perttula 1992:96) because they were distributed along secondary streams, were widely dispersed, and consisted primarily of functionally comparable farmsteads and hamlets. Similar kinds of rural communities occur throughout much of the Caddo area (Story 1982, 1990; Jeter et al. 1989).

Only a small number of Late Caddo period mounds are known in the region, ranging from one to four small mounds per site, and they are unlike the types of mound complexes typically constructed in the major river valleys at this time (Story 1990). Pineywoods mounds were substructural mounds; no pyramidal platform or burial mounds are known for this time period. Substructural mounds are generally restricted to mounds that cap a burned circular structure constructed on the ground surface or in a small, shallow pit. In at least two instances, the mounds contained sequent structures, but the "structures originated at higher levels in the mound[s] due to occupational accumulations of soil and ash, and not the result of any deliberate capping" (Thurmond 1990:168). 
The larger Caddo "towns" were distributed along the major river valleys, such as the Red, Ouachita, and Little. These communities were hierarchically arranged with civic-ceremonial centers (those with platform and burial mounds), associated "towns" of linear but dispersed farmstead compounds with several structures, bark- or brush-covered shelters and storage platforms (Schambach 1983:7-8), hamlets, farmsteads, and specialized processing and/or procurement locales (such as salt-making sites, see Early 1993).

The later Caddo fine wares are stylistically diverse, and there are very specific differences in vessel shapes, designs, and decorative attributes between Caddo ceramics in individual drainages, or even within specific smaller segments of river and creek basins (e.g., Thurmond 1990; Perttula et al. 1998). This diversity can be reasonably interpreted to represent specific Caddo social groups. In historic Caddo times, ceramic vessel forms and decorations are considerably more homogeneous across much of the Caddoan area, suggesting extensive intra-regional contact between contemporaneous Caddo groups (Perttula 1992:154 and Table 14).

\section{Historic Caddo period and entry of Immigrant Indians}

New assessments of the route of the de Soto-Moscoso 1542-1543 entrada through East Texas (Bruseth 1992; Hudson 1997; Kenmotsu et al. 1993; Schambach 1989; Thurmond 1990) indicate that the Spanish entrada encountered several different groups of Caddo peoples from the Red River south to the Nacogdoches area, although the exact route has not yet been determined. Hudson (1997:Map 8) suggests that once the entrada entered Texas-probably in the vicinity of Texarkana-that the Spaniards and their Caddo guides were traveling along a definite aboriginal trail that extended from the Red River southwest into East Texas. The Caddo guides attempted at first to deceive the Spaniards, leading them away from the trails and known villages, but were later executed for these acts when Moscoso discovered he was being misled (Hudson 1997:368).

From Nondacao in the Sabine River basin, which was a prosperous Caddo community where "one could find plenty of corn" (Hudson 1997:365), Moscoso and his men visited Soacatino, possibly in the upper Neches River basin, where corn was scarce, before reaching Guasco on the Neches River, probably near the Caddo trail crossing (now known as the Camino Real) at the George C. Davis site. The Caddo people in Guasco had plenty of corn as well as turquoise and shawls of cotton obtained in trade with Southwestern groups. Hearing of reports by the Caddo of other Spaniards in the area, the entrada moved south or southeast to the Caddo provinces of Naquiscoza and Nazacahoz. Hudson (1997:369-370) and Kenmotsu et al. (1993:Illustration 24 and 25) agree that these Caddo provinces were in the Angelina River basin in the vicinity of the modern community of Nacogdoches. The entrada penetrated no farther south or east, but did move west to the River of Daycao, probably the modern Brazos River (Hudson 1977: Map 8).

It is possible that European diseases were introduced to the Caddo groups living in the East Texas Pineywoods by members of the de Soto-Moscoso entrada (Perttula 1992:27-28), but no evidence is currently available in the archeological or bioarcheological records to substantiate this hypothesis. While it is suspected that the abandonment of certain parts of the Pineywoods in the early to late seventeenth centuries as seen in the archeological record may be a product of population loss, much more archeological investigations at well-dated sites is needed to substantiate disease as the primary contributing factor. 
However, by the late seventeenth century, Hasinai and Kadohadaco Caddo groups in East Texas had been exposed to European epidemic diseases (Derrick and Wilson 2001; Ewers 1973; Perttula 1992, 1996; Swanton 1942), which led eventually to massive depopulation (probably 75-90 percent or more) among these Pineywoods groups by the early part of the nineteenth century.

The first establishment of a Spanish mission among the Hasinai Caddo tribes occurred in 1690. The impetus for this mission was reports of French expeditions and explorations of the area. A second mission was established nearby the following year, but both missions proved unsuccessful and were abandoned in 1693 (Richardson 1958). Renewed French interest in the area resulted in the establishment of six Spanish missions and one presidio within the Hasinai Caddo nation in 1716 and 1717, in the Neches and Angelina river basins. The Spanish again abandoned the East Texas missions in 1719 and withdrew to San Antonio due to a perceived threat of French invasion of the area (Faulk 1965). The Spanish then reestablished six missions in East Texas in 1721, eventually founding Los Adaes (now in Natchitoches Parish, Louisiana) as the capital of the Spanish province of Tejas (Perttula 1992). The missions were again abandoned for the final time in 1773 (Chipman 1992). Four years later, Spanish settlers returned to East Texas and rebuilt the settlement of Nacogdoches (Carlson and Corbin 1999).

In historic times, the archeology of the East Texas Caddo groups living along the middle reaches of the Sabine River and its tributaries have been included in the Kinsloe phase, dated approximately A.D. 1650-1800 or later. Late eighteenth to early nineteenth century Nadaco or Anadarko Caddo sites have been reported along the Sabine River in the Potters Creek area, along trail crossings of this stream (Jones 1968; Clark and Ivey 1974). The Kinsloe phase Caddo groups were part of what has come to be called the Hasinai confederacy (Swanton 1942). Kinsloe phase sites are small dispersed settlements with associated cemeteries. Their material culture included grog-tempered plainware vessels, Simms Engraved carinated bowls, Natchitoches Engraved bowls and bottles, and a punctated-incised utility-ware jar that closely resembles Emory Punctated-Incised, plus trade vessels from other Caddo groups (Perttula 2007). There are also ceramic elbow pipes, triangular arrow points, chipped knives, gunflints (both native and European), as well as a variety of goods obtained from Europeans, among them glass beads, muskets, lead balls, axes, ornaments, and kettles.

Excavations at the Deshazo site (41NA13), the best studied historic Caddo settlement in East Texas (Story 1982, 1995), indicates it was a small centralized hamlet of an affiliated group with a series of circular structures and an associated household or family cemetery. Most sites were apparently occupied for only short periods of time, perhaps an average of 20 to 40 years, based on an analysis of structure rebuilding episodes at the Deshazo site (Good 1982:67-69).

While a single farmstead may have only included one or two structures, Caddo communities were apparently composed of many farmsteads spread out over a considerable distance. In 1687, in the community of Nabedache Caddo (one of the Hasinai groups) on San Pedro Creek in Houston County, Henri Joutel noted:

we took the path to the village where the Indians conducted us to the chief's hut which was a long league's distance from the entrance to the village. On the way, we passed several huts that were grouped in hamlets; there were seven or eight of them, each with twelve to fifteen huts together with space between each other and fields around the huts. (Foster 1998:206) 
Morfi (1935:87) further commented (based on earlier missionary reports) that in 1716, the Nacogdoche Indians were "divided into 22 rancherias ... which spread for a distance of 10 leagues from South to North."

Individual Hasinai Caddo families lived in their farmsteads, several of which have been archeologically investigated in Nacogdoches County (Story 1982, 1995; Kenmotsu 1992), and a number of farmsteads were organized into rancherias spread out over about 15 to 30 leagues (about 40 to 80 miles). Each rancheria was separated from the others by unoccupied lands (see Foster 1998:208) and hunting territory.

There are other clusters of historic Caddo archeological sites in East Texas. First among these are Allen phase components in the Neches and Angelina river basins in Cherokee, Anderson, Houston, Rusk, and Nacogdoches counties (see Cole 1975; Kenmotsu 1992; Perttula and Nelson 2006, 2007; Story 1982, 1995). These usually contain small amounts of European trade goods found in village and burial contexts. Caddo domestic remains at these settlements included a variety of decorated and plain ceramic fine wares (principally Patton Engraved) and utility wares, usually bone-tempered and with brushed vessel bodies, triangular and stemmed arrow points, elbow pipes (plain and decorated), ground stone tools, and bone tools. These Caddo groups were successful agriculturists. Next is a series of probable early eighteenth century Nasoni Caddo sites on the lower Sulphur River (Dickinson 1941; Harris et al. 1980; Lewis 1987), along a known trade portage. Along the Red River in Bowie County, there are archeological remains of Nasoni Caddo and other Kadohadacho tribes that lived in the area until the late 1780s (Miroir et al. 1973; Gilmore 1986; Wedel 1978); the French built a trading post in the early eighteenth century at the main Nasoni village, probably the Roseborough Lake site (41BW5). In the upper Sabine River basin, the Gilbert and Pearson sites (Duffield and Jelks 1961; Jelks 1967) were occupied primarily in the mid- to late-eighteenth century, apparently by Caddo groups who were heavily involved in the fur trade (Perttula 1992:173, 256).

Other Native American groups eventually immigrated to East Texas. In the 1780s, a group of Koasati (Coushatta), former members of the Creek Confederacy, settled here after moving from above presentday Shreveport on the Red River (Gadus and Howard 1989; Hook 1997; Martin 2001; Swanton 1946). Various bands of the Choctaw had also moved into the region by 1830 (Carlisle 2001; McKee 1989). Cherokee were first reported in northeast Texas in 1807 (Lipscomb 2001a; Perdue 1989) with nearly 400 Cherokee settled in the region north of Nacogdoches by 1830 (Cliff and Sills 2004). These migrations were followed by the Delawares around 1820 (Lipscomb 2001b), the Shawnees in 1822 (Lipscomb 2001c), and the Kickapoos in the early 1800s (Nunley 2001). Following the signing of the Caddo Treaty of 1835, Caddo groups from northwestern Louisiana were forced to settle in Texas or Indian Territory (Flores 1984; Lange 1974; Neuman 1974; Smith 1995; Swanton 1946; Williams 1974). Until the early nineteenth century, much of Rusk County was largely populated by the Caddo, Cherokee, and Shawnees tribes, and remained generally unsettled by Europeans.

Most of the Shawnee and Cherokee were removed from this area of Texas following the Cherokee War of 1839, opening the area for white settlement. The establishment of the First United Methodist Church of Henderson in 1842 as part of the Shawnee mission (THC n.d.) suggests that some Shawnee remained in the area following the Cherokee War. Following Texas statehood, remaining Caddos and Shawnee were removed to a reservation on the upper Brazos River in 1855 (Arnold 2007) and then forcibly moved to the Indian Territory (Oklahoma) in 1859 (Lipscomb 2001a, 2001b, 200lc). 


\section{Anglo-American, post-1830s History}

The first Anglo-American settlers from the United States entered into East Texas during the Mexican period. The empresario system of colonization was first implemented with Stephen F. Austin's recruitment of immigrants from the United States in 1821. Immigration to Texas soared with the granting of twenty-five empresarios by 1825. Despite Mexican restrictions on immigration, the flow of new settlers to the region continued to grow. By 1835 an estimated 20,000 Anglo-Americans and their slaves were in Texas. Settlement in East Texas concentrated in the vicinity of Nacogdoches and San Augustine (Moncure 1984). Daniel Martin, for whom Martin Creek was named, received a half-league grant in Rusk County and settled his family of eight in the area of Hogan's Bayou in 1833 (see also Dockall et al. [2009:38-46] for historical background details on the Anglo- and African-American settlement of Rusk County).

Following the Battle of San Jacinto and the establishment of the Republic of Texas, immigrants continued to be attracted to the new Republic of Texas by offers of large land grants. The constitution of 1836 granted extensive headrights to all who were in Texas at the time of the declaration of independence from Mexico. Heads of families entering Texas between March 2, 1836, and October 1, 1837, were allowed 1,280 acres, and single men received 640 acres. Grants were also given for military service, service at the Battle of San Jacinto, or a variety of other services or for residence on and improvements of lands. The Cherokee Wars began in July 1839 as a result of an attempt to dispossess the Cherokee of their lands north of the San Antonio Road and west of the Angelina and Sabine rivers. The burning of Cherokee and Caddo villages led to Indian raids on Anglo-American settlements. As a result of these raids, Daniel Martin and John Irons built a small fort, which later became known as Martin's Creek (Clark and Ivey 1974). Following the Cherokee wars, the Cherokee treaty lands opened to Anglo-American settlement. Large plantations with numerous slaves were established in Rusk County along major streams and roads, while dispersed hamlets of 10-12 farmstead clusters occurred in areas away from major streams where wells could be dug (Jackson 1982).

The community of Harmony Hill emerged following Texas statehood in 1846 (see Dockall et al. 2009:5253). According to local tradition, the community began as a rural settlement called Nip-n-Tuck established on the northwest corner of Daniel Martin's half-league at the intersection of the Henderson-Shreveport and Camden roads (Clark and Ivey 1974). The western portion of Martin's league was sold to Leonard Tomlinson in May 1849 and, in February 1853, John Kuykendall was designated as title holder of the tract, although the land was not officially deeded to Kuykendall until March 27, 1854 (Clark and Ivey 1974). Kuykendall laid out the township, divided it into lots, and began selling sections in 1855. No mention is made of any previously existing structures in the original deeds (Clark and Ivey 1974). By 1860 there were eight to ten stores, a post office (which was in service between 1854 and 1905), a small furniture factory, a blacksmith shop, two churches, a Masonic hall, and a school in addition to several houses (Winfrey 1961). At least one gin mill, a grist mill, and a saw mill were in operation in the area prior to the Civil War in addition to a shoe shop and a wheelwright's shop (Farmer 1951).

Following the Civil War the community of Harmony Hills entered its most prosperous period, culminating in the mid-1880s, when the population peaked at about 100 citizens and the town had three churches, four steam cotton gins, three gristmills, and a district school (Clark and Ivey 1974). Businesses in town included three mercantile stores, a drugstore, and a saloon (Farmer 1951). In the 1890s the primary economic activity in the area was agriculture. Primary crops included cotton, corn, oats, hay, and potatoes. 
Fruit orchards, especially peach, also became numerous (Richardson 1940). Before construction of the railway, Harmony Hill enjoyed an advantageous location on the major routes between Rusk County and markets not far to the east in Shreveport. The community sharply declined following the establishment of the Longview and Sabine Valley Railway across the northeast corner of the county and as Tatum became the commercial center of the county (Dockall et al. 2009:53). By 1900, the town of Harmony Hills was all but abandoned, with only a few families residing there. A tornado destroyed most of the town's buildings in 1906, and no interest was shown in rebuilding (Farmer 1951; Winfrey 1961). By 1939, only three houses constructed prior to the Civil War still stood in the abandoned town. During Clark and Ivey's survey in 1972, only one of these houses remained, and it was used as a storage shed (McDonald 1972; Clark and Ivey 1974). 



\section{Chapter 4}

\section{Previous Investigations in the Martin Creek Lake State Park Area}

The construction of the Martin Lake Steam Electric Station in Rusk and Panola Counties initiated archeological investigations of the area in 1972 (McDonald 1972; Clark and Ivey 1974). During the initial phase of investigations, 41 sites were identified, 20 of which were recommended for additional investigations (Clark and Ivey 1974), leading eventually to the recording of another nine sites. During this series of archeological investigations, the community of Harmony Hills (adjacent to and extending into the current project area) was initially examined. The historic community of Harmony Hills was nominated to the National Register of Historic Places (NRHP) on September 29, 1975 and certified as a NRHP District on May 13, 1976.

The 1972 Clark and Ivey (1974; see also McDonald 1972) survey identified and/or investigated seven sites located within the current boundaries of the Park: 41RK9, 41RK43, 41RK66, 41RK67, 41RK69, 4lRK71, and 41RK133. Two additional sites, 41RK466 and 41RK467, were identified during a 1996 survey by Stephen F. Austin State University Anthropology Laboratory. (These site locations are shown on the map in Appendix 1. No report is available from this survey.) 



\section{Chapter 5}

\section{Methods of Archeological Survey}

CAS proposed to conduct the cultural resources inventory survey at the Park following guidelines established by the Texas Historical Commission (THC), the Council of Texas Archeologists (CTA), and TPWD. Both pedestrian survey and intensive shovel testing were employed in the completion of the investigations.

Before beginning the survey, the Park's 287 acres was divided into areas of high, moderate, and low probability (within the Park itself) for containing sites (Figure 4). Each area was then systematically surveyed by following pedestrian transect lines spaced approximately $30 \mathrm{~m}$ apart, following the trend and slope of landforms. High probability areas were to be sampled by shovel test units (ST) excavated at a rate of at least three (3) ST per acre. Moderate probability areas were to be sampled at a rate of one (1) ST per acre, and low probability areas were to sampled at a rate of one (1) ST per every three acres. The projected rates of Park coverage are indicated in Table 1.

Table 1. Park acreage by probability area and projected intensity of survey effort.

\begin{tabular}{lcc}
\hline Probability & Total Acreage & Total No. of STs \\
\hline High & 46 & 138 \\
Moderate & 75 & 75 \\
Low & 166 & 55 \\
Totals & 287 & 268 \\
\hline
\end{tabular}

As shown in Table 1, no fewer than 268 shovel test units were to be excavated at the Park, at a rate of 0.9 shovel tests per acre across the Park as a whole. In actuality, a total of 423 shovel tests were excavated in the different probability areas and on sites in the Park (Figure 5 and Appendix 2), resulting in a rate of 1.48 shovel tests per acre; in high probability areas, for example, 4.0 shovel tests were excavated per acre. The breakdown of shovel tests excavated in each of the probability areas is provided in Table 2. Only 36 of the excavated shovel tests ( 8.5 percent) in the Park contained prehistoric and/or historic artifacts.

Table 2. Shovel tests excavated in the different probability areas.

\begin{tabular}{lccc}
\hline Probability Area & Total Acreage & No. of ST & ST/acre \\
\hline High & 46 & 184 & 4.0 \\
Moderate & 75 & 143 & 1.9 \\
Low & 166 & 96 & 0.6 \\
Totals & 287 & 423 & 1.48 \\
\hline
\end{tabular}

Shovel test units were to be excavated to a maximum of $1 \mathrm{~m}$ in depth, or until bedrock or the clay B-horizon subsoil layers were reached. Soils were screened through a 1/4-inch mesh screen to recover any artifacts in the soil matrix; all cultural materials were collected from the shovel tests that produced artifacts. Soil descriptions and materials recovered were noted in standardized shovel test forms (see Appendix 


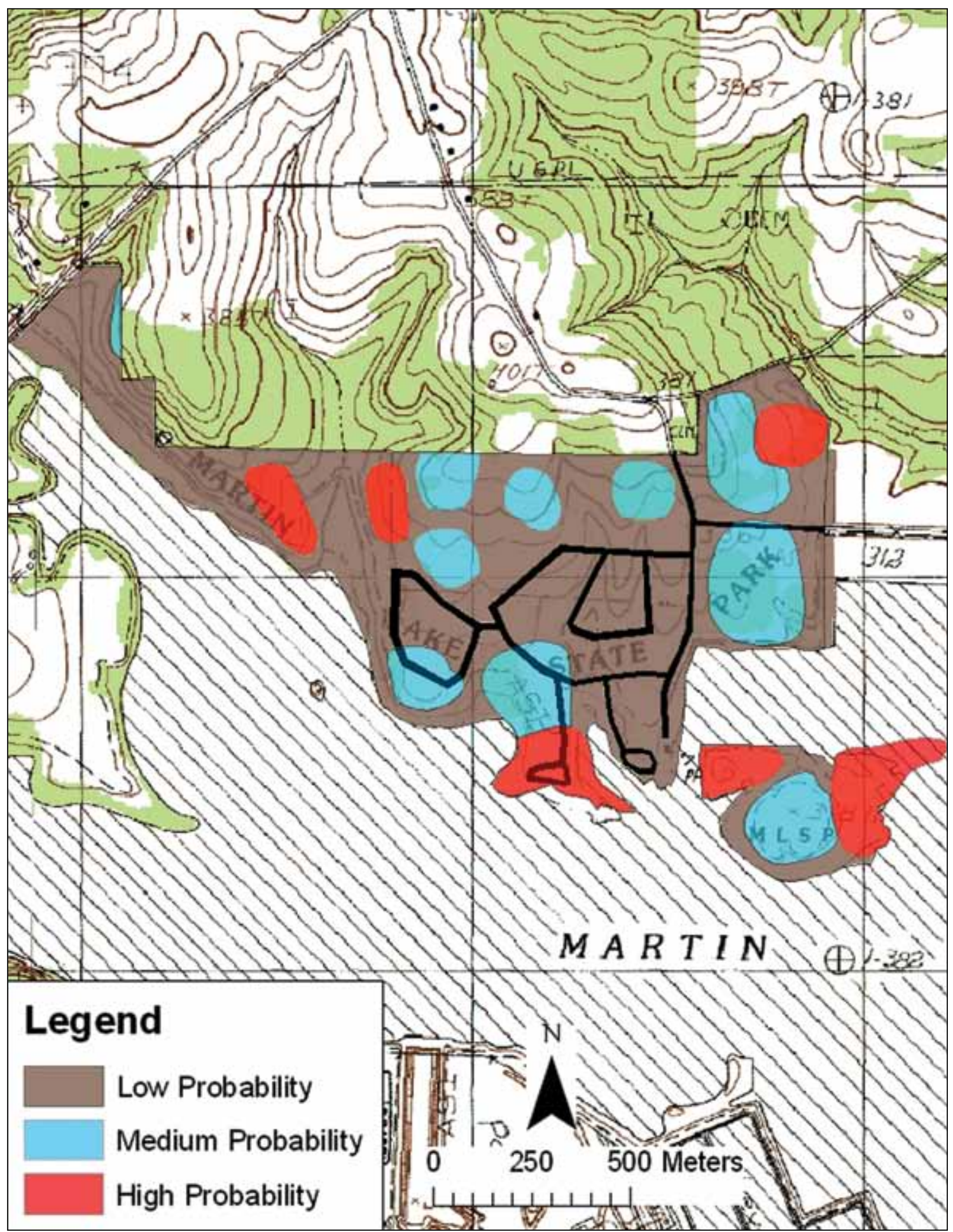

Figure 4. Martin Creek Lake State Park showing high (red) and moderate (blue) probability areas. All other areas are low probability (in brown) Park areas. 


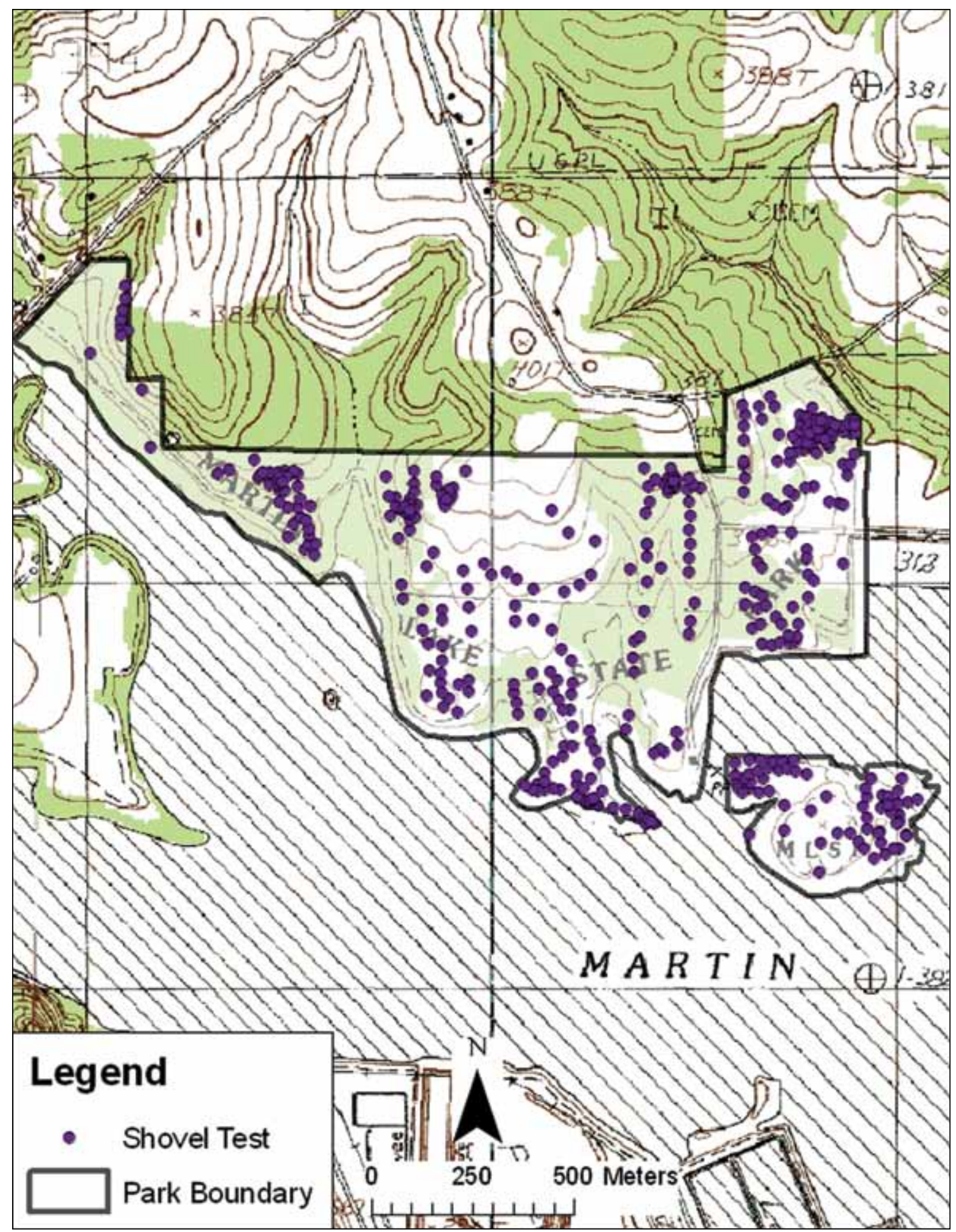

Figure 5. Distribution of all shovel tests excavated at Martin Creek Lake State Park during the 2010 archeological survey. 
2). All shovel test locations were recorded with a handheld GPS unit with sub-meter accuracy. Temporally diagnostic artifacts encountered on the surface during pedestrian survey were to have been collected and their locations also recorded with the GPS, although none were encountered during the survey.

The purpose of the archeological survey was to identify and spatially locate any prehistoric and historic sites in the Park, including sites that had been previously recorded. Shovel test units were excavated in a cruciform or grid pattern around a positive shovel test unit until the area was delimited by two negative shovel test units in each direction. No fewer than eight shovel test units were excavated on each site unless the site extended beyond the Park boundaries; shovel testing halted at the Park boundary.

All site locations were recorded with a handheld GPS unit with sub-meter accuracy and all data was transferred to a GIS format. GPS data were exported into an ESRI Shapefile. A centroid and site boundaries were recorded for each site. Additional GPS data obtained included the locations of all shovel tests, archeological features, structures and buildings, and any other elements related to the investigations. All GIS data created are in a Spatial Data Standards (SDS) and have Federal Geographic Data Committee (FGDG) compliant metadata. The projection of the GIS data is in UTM zone 14 North and datum NAD83.

Digital photography was used to document all sites in the Park. At minimum, this included two general overviews of each site illustrating the site setting (terrain, vegetation, etc.). Additional photos of survey work, buildings and structures, and any other relevant features are also included. A "contact sheet" or thumbnails of all digital photographs has been submitted to TPWD. A photo log was maintained and completed in the field and a photo log database was created to serve as a final deliverable to TPWD in a digital format as well as archived with other project records at TPWD.

The context, depth, extent, and artifact content of all sites were to be obtained through pedestrian survey and shovel testing. Only buildings and structures greater than 45 years old were to be documented during the survey investigations. Documentation included sketch maps, photographs, and GPS location coordinates. All sites that had been recorded more than five years ago within the project area were also resurveyed and accurately mapped, so as to be able to describe and characterize their current conditions. Sketch maps were created for each identified/revisited historic and/or archeological site and accompanied the TexSite Archeological Site Data Form submissions. Maps include magnetic north, scale, visible features, shovel test locations, roads, streams, or landforms that would aid in relocating the sites, and were present at specific sites. Sites were plotted on 7.5-minute Series USGS quadrangles, along with the centroid and estimated site boundary. Texas Archeological Site Data forms, including update forms, were submitted in TXSITE database and paper forms to the Texas Archeological Research Laboratory. Original field site forms have been submitted to the TPWD.

Upon the accidental discovery of human remains, work was to be halted and CAS would notify the TPWD Cultural Resources Coordinator immediately via telephone and e-mail. Care would be taken not to disturb any remains encountered. No human remains were encountered during the present archeological survey.

The analysis of the recovered prehistoric and historic artifacts from the Park sites followed standard approaches in the identification of the age and presumed function of both prehistoric and nineteenth and twentieth century material culture found on sites in East Texas. The few prehistoric artifacts (all chipped stone) that were recovered in the shovel testing and $50-x-50-\mathrm{cm}$ units (see below) were separated into 
categories of unmodified lithic debris and chipped stone tools. The unmodified lithic debris was divided into cortical or non-cortical pieces, and further categorized as complete flakes (with bulbs of percussion) or flake fragments. Among the chipped stone tools, categories were recognized for dart point and arrow point. Dart points are large bifacially worked hafted tools with pointed distal ends and were probably mounted and propelled on an atlatl and spear. Arrow points are small (typically less than $5 \mathrm{~cm}$ in length), bilaterally symmetrical artifacts with a pointed distal end and some facility for hafting at the proximal end. Typological and chronological estimations for the recovered dart and arrow points follow Turner and Hester (1999) and Story (1990:Figure 32).

Historic artifacts were sorted into broad classes by material culture categories-ceramics (refined earthenwares and stonewares), glass (bottles and fruit jars, as well as snuff and window glass), and metaland further sorted by apparent function, such as clothing items (buttons), agricultural tools and implements, food and liquid containers and food serving ware (most of the bottle and jar glass and recovered sherds of whiteware, ironstone, and several kinds of stoneware), and architectural items (nails, bricks, and asphalt shingles). Establishing the ages of the historic artifacts-and the estimated age of the historic archeological components at the sites-is primarily based on Majewski and O'Brien (1987) for the plain and decorated refined earthenwares; Greer (1981) and Lebo (1987) for stonewares; the Society for Historic Archaeology (2010) for glass bottles and jars; Meissner (1997) for buttons; Wells (2000) and Adams (2002) for square cut and wire nails; and Moir $(1987,1988)$ for window glass, based on changes in pane thickness.

All artifacts collected during investigations will be processed and prepared for final curation according to the standards of the Texas Parks and Wildlife Department Archeology Laboratory. Artifacts will be temporarily curated at CAS with final curation to be at TPWD. 



\section{Chapter 6}

\section{Results of the Archeological Survey}

During the 2010 archeological survey in the Park, four previously recorded archeological sites (41RK66, 41RK69, 41RK71, and 41RK467) were relocated and shovel tested, and 50-x-50- cm units were excavated at each of them. Four new sites (41RK605-608) were also identified and recorded in the Park, and, except for 41 RK608 (segments of the Old Henderson Road), shovel tests and 50- $\times-50-\mathrm{cm}$ units were also excavated at each of them. Three other previously recorded sites-41RK9, 41RK43, and 41RK466—could not be relocated. Site 41RK466 may be currently under water; 41RK9 may have been originally misplotted; and 41RK43 was probably destroyed or covered by a Park parking lot. Three other sites, two previously recorded (41RK67 and 41RK133) and one new historic road (41RK608), were simply documented and photographed. Archeological investigations were not warranted at these three sites because one historic site with preserved archeological deposits is protected within an overgrown but fenced thicket of brush and vines and had previously been the subject of test excavations (41RK67, see Davis et al. 1994), and the other two are historic features-a bridge remnant (41RK133) and an old roadbed (41RK608)-without archeological deposits.

Of the 13 sites that have been recorded and investigated at various times within the boundaries of the Park, seven (4 1RK43, 4lRK66, 41RK67, 4 IRK69, 41RK7 1, 4lRK133, and 41RK608) have only historic components. Another four sites (41RK9, 41RK467, 4lRK606, and 41RK607) have historic components as well as very sparse evidence of prehistoric occupations during Late Archaic, Woodland, and Caddo periods. All the Martin Creek Lake State Park historic sites appear to be associated with the abandoned town of Harmony Hill, although the Harmony Hill Baptist Church (41RK66) was apparently built and used after the town was abandoned. The final two sites (41RK466 and 41RK605) have undetermined prehistoric occupations. The sparse distribution of prehistoric sites or components in the Park area is likely the consequence of the limited distribution of permanent water sources in upland areas. Dockall et al. (2009:227) noted the same low density of prehistoric sites in upland areas in the nearby Rusk Permit Area, commenting that " $[\mathrm{w}]$ ith springs present but not frequent along and at the heads of intermittent, mostly runoff-fed drainages, this area lacks places that would have been suitable for intensive occupation by Native Americans. The few sites that are present are associated with these drainages, but all are sparse lithic scatters reflecting limited use."

\section{Extent of Disturbances within the Park}

Numerous disturbances, both natural and modern in origin, are apparent across the Martin Creek Lake State Park lands (Figure 6). These disturbances have hampered the search for and identification of previously recorded sites as well as unrecorded archeological sites in the Park. Most of the disturbances are apparently associated with the construction of Martin Creek Lake in the 1970s and the subsequent development and maintenance of the Park and its facilities since 1976 (when the Park was opened).

Disturbances have resulted in the removal of much if not all of the sandy $\mathrm{A}$ - and E-horizon sediments from landforms over significant areas within the Park. The A- and E-horizon sediments are the only 
sediments in the Park known to contain archeological deposits of prehistoric and/or historic age. The removal of these sediments-as well as portions of the underlying clay subsoils where substantial use of heavy machinery has occurred-resulted in the exposure of the clay B-horizon subsoil in these areas of disturbances as well as the subsequent construction of facilities in some areas. The various disturbances mapped during this archeological survey are conservatively estimated to cover 128.2 acres, or 44.7 percent, of the Park (Table 3). In other words, because of the past disturbances, the potential for the presence of archeological sites was virtually nil in 44.7 percent of the Park before the 2010 archeological survey was initiated. Another 7.3 percent of the Park acreage is covered by a large area of mounded fill (consisting of gray clay and lignite) (see Figure 6).

Table 3. Kinds of disturbances in Martin Creek Lake State Park and their spatial extent.

\begin{tabular}{|c|c|}
\hline Kind of Disturbance & Estimated Acres \\
\hline Screened shelter construction $(n=21)^{1}$ & 4.2 \\
\hline Cottage construction $(n=2)^{1}$ & 1.2 \\
\hline RV camp sites $(n=62)^{1}$ & 6.1 \\
\hline Primitive campsites $(n=40)$ & 1.0 \\
\hline Restroom facility construction $(n=4)^{2}$ & 0.8 \\
\hline Amphitheatre construction & 0.2 \\
\hline Pavilion construction $(\mathrm{n}=2)$ & 0.6 \\
\hline Day-use area facilities in SE part of Park ${ }^{3}$ & 12.0 \\
\hline Residences $^{1,3}$ & 2.0 \\
\hline Visible sewer, water, and power line construction right-of-ways & 3.2 \\
\hline Paved Maintenance lot & 0.7 \\
\hline Park entrance and store ${ }^{1}$ & 1.1 \\
\hline Wastewater treatment plant construction ${ }^{2}$ & 32.0 \\
\hline Construction of paved roads ( 31 miles of road) & 19.8 \\
\hline Old roadbeds and roadcuts & 3.5 \\
\hline $\begin{array}{l}\text { Construction of trails (bike and hike), and associated erosion from } \\
\text { trail traffic }\end{array}$ & 3.2 \\
\hline $\begin{array}{l}\text { Machine-scraped area associated with lake dam construction, } \\
\text { original Park facilities, and a boat ramp }{ }^{3}\end{array}$ & 31.0 \\
\hline Boundary fence bulldozed perimeter paths ${ }^{3}$ & 5.6 \\
\hline Area of clay-lignite fill on the Island in the Park & 21.0 \\
\hline
\end{tabular}

Breakdowns of the various disturbances by acre are provided in Table 3, and the extent of these disturbances is depicted in Figure 6. The three largest contiguous areas of subsurface disturbances in the Park are:

(1) construction of the wastewater treatment plant area in the north central area. This area has a 


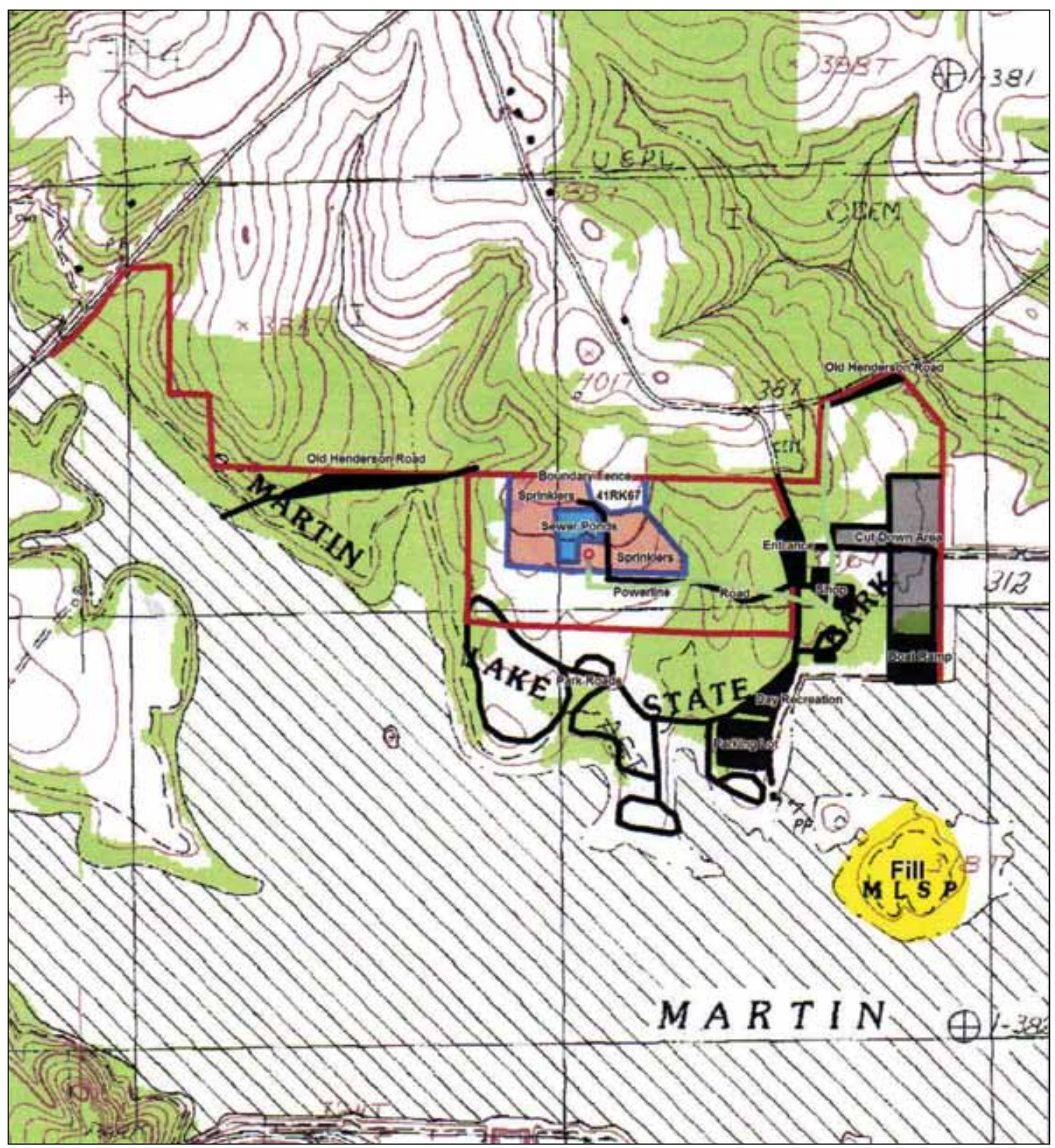

Figure 6. Areas of identifiable disturbances within the boundaries of Martin Creek Lake State Park. 
treatment pond, a holding pond, and a pumping station that brings sewage to the plant. Once the sewage is treated, it is spread over a fenced pasture by a large sprinkler system that is connected by underground irrigation piping;

(2) the machine-scraped or sediment cut-down area and boat ramp in the eastern part of the Park, along part of the lake shoreline. It appears that at least $1-2 \mathrm{~m}$ of sediments have been mechanically removed over a large rectangular area, and there are concrete slabs here, as well as a large boat ramp;

(3) the day-use facilities and parking lot in the southeastern part of the Park, also situated in part along the Martin Creek Lake shoreline. This area has been the scene of past heavy machinery disturbances, which removed 1-2 m of sediments; much of this area was then covered with a paved parking lot. Boat launches, group picnic areas, and playground equipment in the day-use area have also contributed to the subsurface disturbances.

\section{Shovel Test Coverage and Sediment Depth}

A large number of shovel tests have been excavated to identify and/or relocate archeological sites within the Park (see Figure 5). Varying rates of shovel tests per acre were employed across the Park depending upon the distribution of high, moderate, and low probability areas (see Figure 4), and it was determined from this shovel testing that there was a low density of either prehistoric and/or historic archeological deposits across the Park. The shovel testing has also shown that the sandy loam A- and E-horizon sediments in the Park are generally shallow (i.e., less than $45 \mathrm{~cm}$ thick) (Table 4; see also Appendix 2). Approximately 75 percent of the shovel tests excavated in the Park have A- and E-horizons that are less than $45 \mathrm{~cm}$ in thickness overlying a clay subsoil; about 20 percent of these shovel tests encountered the clay B-horizon subsoil at less than $15 \mathrm{~cm}$ bs.

Table 4. Depth to the clay subsoil in Martin Creek Lake State Park shovel tests.

\begin{tabular}{lcc}
\hline \multicolumn{1}{c}{ Depth to clay subsoil } & No. of Shovel Test & Percentage \\
\hline Less than $15 \mathrm{~cm}$ bs & 63 & 14.9 \\
$16-30 \mathrm{~cm}$ bs & 150 & 35.5 \\
$31-45 \mathrm{~cm}$ bs & 103 & 24.5 \\
$46-60 \mathrm{~cm}$ bs & 53 & 12.5 \\
$61-75 \mathrm{~cm}$ bs & 12 & 2.8 \\
$76-90 \mathrm{~cm}$ bs & 2 & 0.5 \\
Greater than $90 \mathrm{~cm}$ bs & 10 & 2.4 \\
C-horizon encountered at & 2 & 0.5 \\
less than 30 cm bs & 28 & 6.6 \\
Disturbed sediments & 423 & 100.0 \\
Totals & & \\
\hline
\end{tabular}

Shovel test data indicate that very shallow sandy loam sediments are well distributed across the Park (Figure 7). They are particularly concentrated in sloping upland landforms and toe slopes above $320 \mathrm{ft}$ 


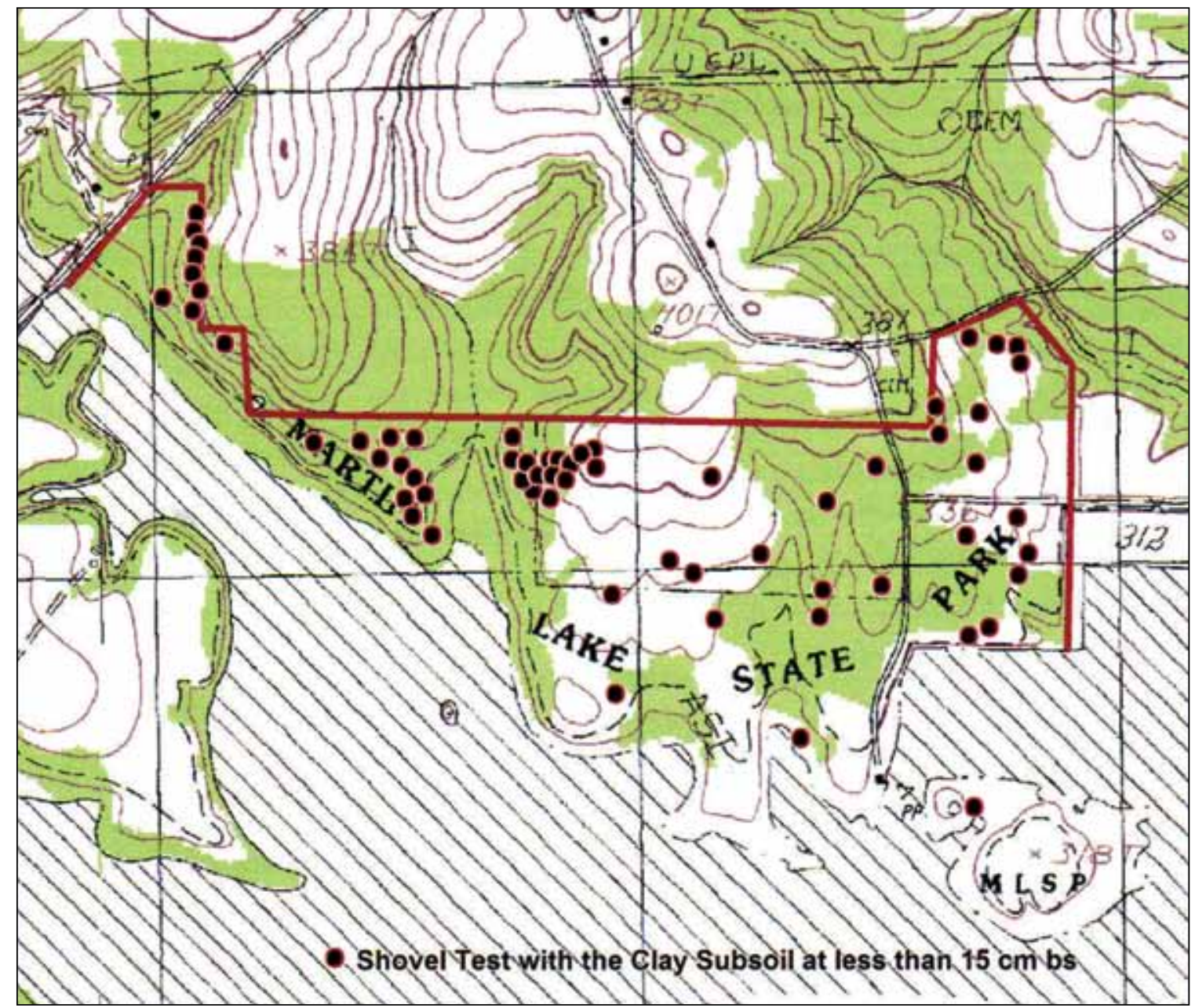

Figure 7. Distribution of shovel tests excavated in Martin Creek Lake State Park where the clay subsoil was encountered at less than $15 \mathrm{~cm}$ bs. 
amsl, suggesting that the thickness of the A- and E-horizon sediments is at least partially affected by slope erosion, although less steeply sloping upland landforms in the western part of the Park also have very shallow sandy loam sediments.

Very shallow sediments within much of the Park are also documented by results of shovel tests in which 0.5 percent of the tests encountered C-horizon deposits (i.e., sandstone rocks) at less than $30 \mathrm{~cm}$ bs (see Table 4).

Thicker sandy loam A- and E-horizon sediments-greater than $61 \mathrm{~cm}$ in thickness-were encountered in only 5.7 percent of the excavated shovel tests (see Table 4). The thickest sandy loam sediments are present in one small area near the Martin Lake shoreline in the southern part of the Park, where Attoyac fine sandy loam sediments more than $90 \mathrm{~cm}$ thick are present (Figure 8). About 1.2 percent $(n=5)$ of the shovel tests, all in this one area, never encountered the clay B-horizon subsoil. One prehistoric site (41RK605) with very sparse archeological materials was located in this area (see below).

Almost 7 percent of the excavated shovel tests across the Park encountered disturbed sediments and fill deposits. None of these shovel tests had any remaining A- and E-horizon sediments.

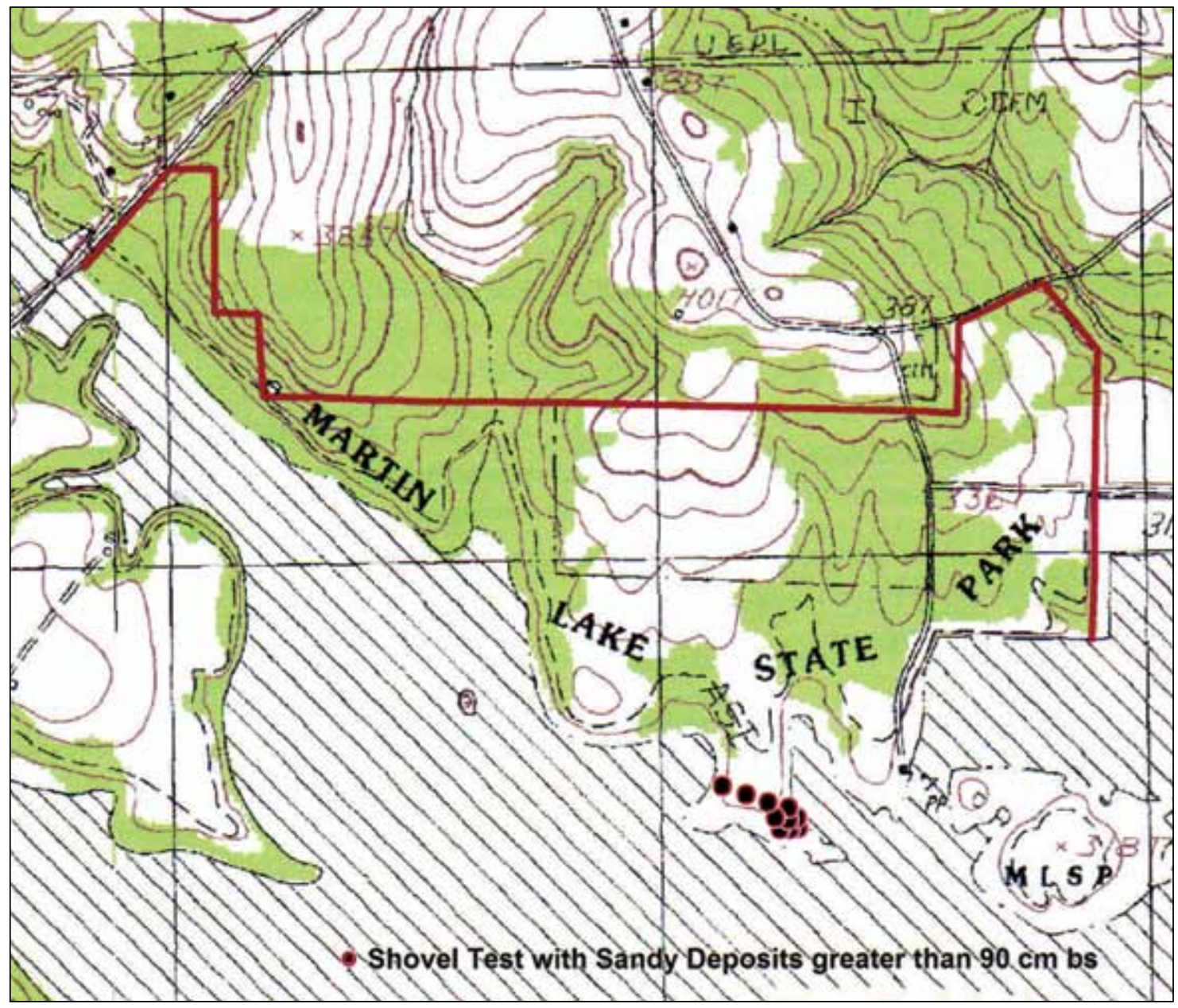

Figure 8. Distribution of shovel tests excavated at Martin Creek Lake State Park where the sandy A-and E-horizon sediments extend to more than $90 \mathrm{~cm}$ bs. 


\section{Investigations at Previously Recorded Sites}

\section{RK9}

This site, as recorded in 1972 (McDonald 1972), was a mid-nineteenth century farmhouse and a yard artifact scatter. The house was possibly occupied by W. Dollhite after 1851, in the Harmony Hill community. The site was marked by a small foundation mound $(5.5 \times 11.0 \mathrm{~m})$ with bricks and rock piers (McDonald 1972:7). Ferruginous sandstone foundation rocks were present in one part of the site, associated with whiteware sherds (plain, hand-painted and transfer-printed), salt-glazed sherds, stove parts, machine-cut square nails, and bottle glass sherds. It was situated on an upland landform just east of a small tributary to Panther Creek.

Test excavations were conducted at the site in 1972 (McDonald 1972:7-8). A single 1-x-2-m unit was excavated in the house foundation area, and archeological deposits with nineteenth century artifacts were recovered to a depth of $60 \mathrm{~cm}$ bs. Recovered artifacts included stoneware and refined earthenware ceramics, most notably mid-nineteenth century hand-painted, blue shell-edged (ca. 1840-1860 style, see Hunter and Miller 1994, 2009), and transfer-printed wares, porcelain and shell buttons, window glass sherds, bottle glass sherds, many cut nails, brass, pewter, lead, and iron artifacts, and animal bones. A very small amount of probable prehistoric Caddo artifacts (a few sherds and chipped stone fragments) were recovered in the archeological deposits. McDonald (1972:8) recommended "limited testing...to ascertain characteristics of the dwelling and possible outbuildings," but the recommended work was not done before construction of Martin Creek Lake.

This site was not relocated during the 2010 archeological survey. Shovel tests at the location plotted in the Texas Historic Sites Atlas (see Appendix 1) of 4lRK9 along the shoreline of Martin Creek Lake (ca. 20 $m$ north of ST 276, based on the site form description of its location as determined by John Clark) did not recover any historic or prehistoric artifacts or archeological deposits, and the described foundation stones and bricks were not detected (see McDonald 1972). This part of the Park is covered in pine and hardwood vegetation, and there are several primitive camp sites in the area.

It is possible that the location of 41RK9 was either misplotted on the Texas Historic Sites Atlas or was destroyed during lake construction. The north shoreline of the lake at this point has been mechanically altered and sediments have been removed (see Appendix 1 and Figure 6). The site could possibly now be under water, although the site form indicates that its elevation was $307 \mathrm{ft}$ amsl, about $2.5 \mathrm{ft}$ above the 2010 lake level when the survey was conducted. McDonald (1972:7) did state, however, that "at the anticipated flood level of Martin Lake, the site will be subject to inundation."

\section{$41 R K 43$}

4 lRK43 is also a farmhouse site, occupied in the early part of the twentieth century, situated on a low knoll (310 ft amsl) overlooking to the east a tributary of Panther Creek (see Appendices 1 and 3). Observed archeological remains included a scattered brick chimney, wire nails, ceramic sherds, and bottle glass sherds (McDonald 1972:30).

This site was also not relocated during the 2010 archeological survey of Martin Creek Lake State Park. Its plotting (see Appendix 1) indicates that it was either destroyed during lake construction, as it was shown 
in an area where there has been extensive heavy machinery work (see Figure 6), or its location now lies underneath the large TPWD parking lot in the day-use area (see Figure 6), where it was likely destroyed during the construction of Park facilities. Shovel tests excavated in areas not covered by the parking lot and road pavement, areas planted in grass and trees, encountered only disturbed sediments (i.e., there were fragments and chunks of concrete in the sediments). Picnic tables, a restroom, a pier, a fish-cleaning station, and a boat ramp are also present in this part of the Park.

\section{RK66, Harmony Hill Baptist Church}

The Harmony Hill Baptist Church site was first recorded in 1973 as the location of a 1930s-era church about 250 m east of the Harmony Hill Cemetery, along an old road trace. This site is on an upland slope (310-320 ft amsl), about $120 \mathrm{~m}$ west of a small tributary to Martin Creek. When the site was recorded in 1973, the only archeological evidence apparent were a few pieces of hematite, perhaps remnants of foundation piers. The site area was heavily overgrown at that time with brush and vines.

The site is currently wooded with mature pines and oaks, with a thick brush (holly) and vine understory. The presence of privet, mulberry, chinaberry, and honeysuckle suggest that historic structures may have once existed on the site,. There is evidence (push piles of displaced sediments) that portions of the site have been scraped at one time or another in the past. Surface visibility was less than 10 percent.

During the current archeological investigations, extensive shovel testing $(n=41)$ was completed across the landform. Seven shovel tests contained historic archeological deposits at 0-20 cm bs (Figure 9). The estimated extent of the site is $2000 \mathrm{~m}^{2}(0.5$ acres). The area of the twentieth century church is in the northern part of the site, in the vicinity of ST 137, while earlier mid- to late nineteenth century archeological deposits are present in the southern part of the site. Displaced sandstone rocks are present in both parts of the site, likely foundation stones for a structure. A cleaned-out spring, with a soil berm around it, is just to the north of the site (Figure 9).

The 50-×-50-cm unit (Unit 387) was $20 \mathrm{~cm}$ east of ST 182, and near one of the apparently displaced large sandstone rocks (footing stones or rock piers) noted during the pedestrian examination of the site; brick fragments were also present, under a mulberry tree, and probably represent remnants of a structural foundation (see Figure 9). Historic artifacts were recovered from $0-20 \mathrm{~cm}$ bs and $30-35 \mathrm{~cm}$ bs in Zone 1 (dark grayish-brown sandy loam, 10YR 4/2 and Zone 2, a yellowish-brown sandy loam, 10YR 5/6) sandy loam zones (Figure 10a). Zone 3 is a strong brown (7.5YR 5/8) sandy clay B-horizon.

A total of 32 historic artifacts were recovered from 41 RK66 in the shovel testing ( $n=26$, from a total of seven positive shovel tests) and one 50-x-50-cm unit $(n=6)$. (See Appendix 4 for 41 RK66 and the other sites for a complete artifact inventory by provenience.) In the shovel tests, all artifacts were found only at 0-20 $\mathrm{cm}$ bs, while 83 percent of the artifacts from Unit 387 are from those depths; one cut nail was recovered at $30-35 \mathrm{~cm}$ bs in this unit. The density of artifacts in the shovel testing is 3.71 artifacts per positive shovel test, or approximately 29.7 artifacts per $\mathrm{m}^{2}$. In the $50-\times-50-\mathrm{cm}$ unit, the density of artifacts is 24.0 per $\mathrm{m}^{2}$, and 69 artifacts per $\mathrm{m}^{3}$.

The historic artifacts recovered in the investigations at 41RK66 suggest that there was a late nineteenth century occupation here prior to the construction and use of the Harmony Hill Baptist Church (Table 5). These artifacts are all from ST 182 and Unit 387 in the southern part of the site, with the exception of a hand- 
FIGURE 9. REDACTED

Figure 9. Map of 41RK66. 
made brick fragment from ST 178, about $20 \mathrm{~m}$ away (see Figure 9). The combination of hand-made bricks, cut nails, window glass (estimated manufacture date of $1884.5 \pm 7$ ), and domestic artifacts (ceramic sherds and bottle glass) suggest that the late nineteenth century occupation had a farmstead structure on it. This structure was abandoned and probably torn down well before the Harmony Hill Baptist Church was built.

Table 5. Historic artifacts from 41 RK66.

Late nineteenth century artifacts from shovel tests and $50-x-50-\mathrm{cm}$ unit

1 aqua window glass, $2.04 \mathrm{~mm}$ thick (1884.5 \pm 7, Moir 1987, 1988)

2 hand-made brick fragment

2 cut nails (1820-1891, Wells 2000)

1 salt-glazed stoneware sherd

2 plain whiteware sherds

1 brown bottle glass sherd

Likely early to mid-twentieth century artifacts from shovel tests and 50-x-50-cm units, associated with the Harmony Hill Baptist Church

13 clear bottle glass sherd

1 white milk glass sherd, cosmetics container

1 fruit jar zinc lid

6 white milk glass fruit jar lid liner sherds

Salt-glazed stoneware was a popular utilitarian ware throughout much of the nineteenth century (Greer 1981:180). It increased in popularity in East Texas during approximately 1850-1870, then declined in popularity by 1900 (Lebo 1987:140). The one sherd from 41RK66 had an exterior salt glaze over a gray-colored vessel body (Figure 11).

The twentieth century artifacts from 41RK66 (see Table 5) include sherds from glass containers (bottles and fruit jars) as well as zinc lids and lid liners to fruit jars. Zinc lid liners, along with the milk glass lid liner inserts, were used up until about 1940 for fruit jars (Brantley 1975). Perhaps these artifacts represent the discarded remains of containers holding foods used for meals served at the church.

Two clear bottle glass sherds exhibit marks on their bases. The first, from ST $178(0-20 \mathrm{~cm})$, is likely from an extract bottle. The visible mark is "688 N..." The " $N$ " is enclosed within a square, suggesting it was made by the Obear-Nester Glass Company after 1894 (Whitten 2010). The second clear bottle base sherd (ST 180, 0-20 cm bs) exhibits a mark consisting of "M-54" followed by a centrally placed B inside a circle, followed by " 648 ". The mark containing B inside a circle suggests the bottle may have been made by the Brockway Machine Bottle Company after 1925 (Whitten 2010).

\section{RK67, J. M. Robertson House}

The J. M. Robertson House, a contributing element in the Harmony Hill National Register of Historic Places District, when first recorded was thought to be an Anglo-American farmstead with the remains of a stone foundation (and some foundation beams) as well as one or two wells. More information was obtained about the site through an investigation in 1987 by Texas Parks and Wildlife "to mitigate the adverse effects of sewer treatment plant development southwest of the site" (Davis et al. 1994:3). The site, now in a fenced 


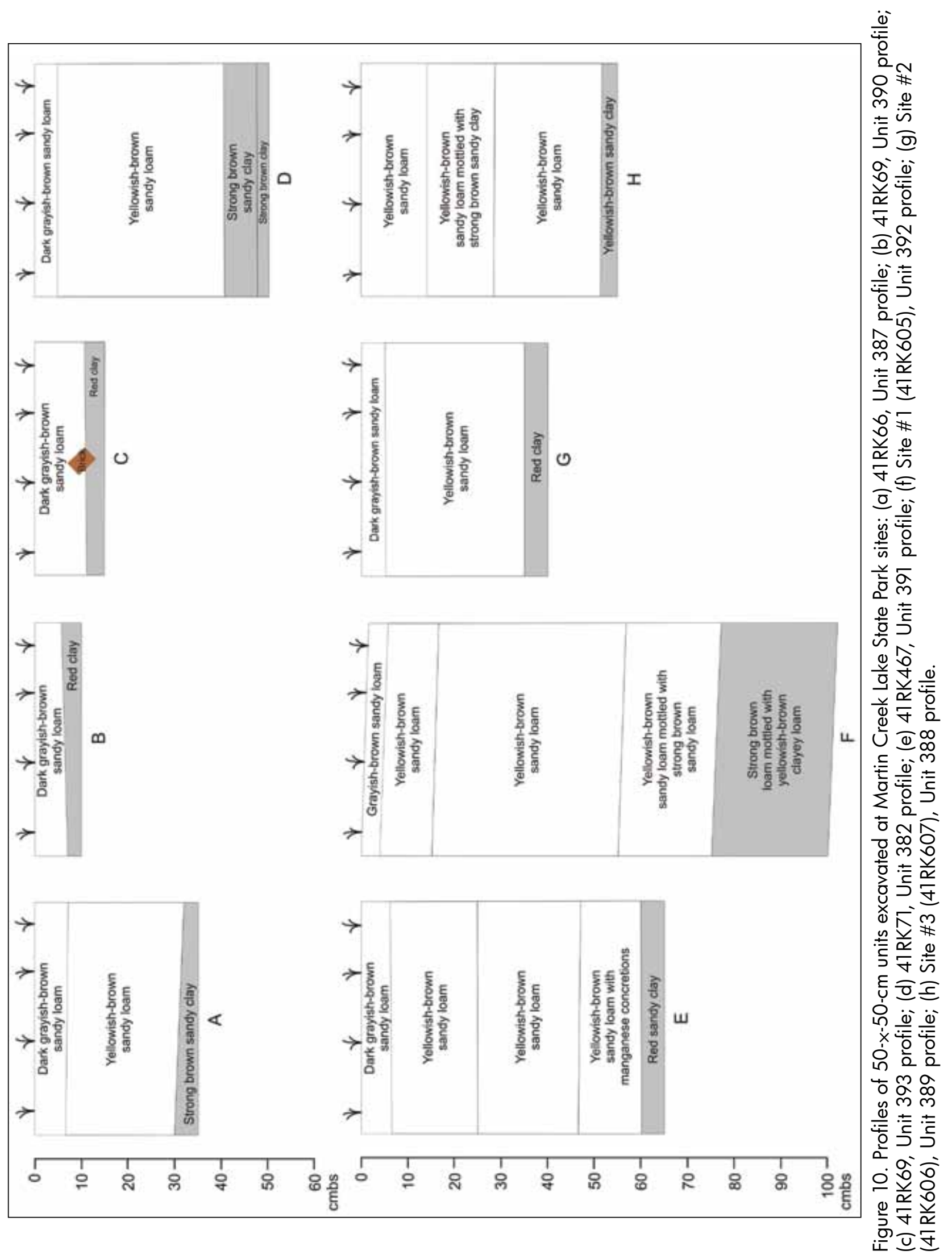


area, is situated on an upland slope (360 ft amsl) south of the Old Henderson Road (41RK608).

Historic records indicate that J. M. Robertson, a mercantile store owner in Harmony Hill, bought the property on which the site is located in 1869 (Davis et al. 1994:18). In addition to the main house, the property also apparently had a barn, two smaller outbuildings, a possible privy, as well as a hand-dug well, and trash pit features (Davis et al. 1994:23).

The 1987 archeological investigations included mapping, photography, surface

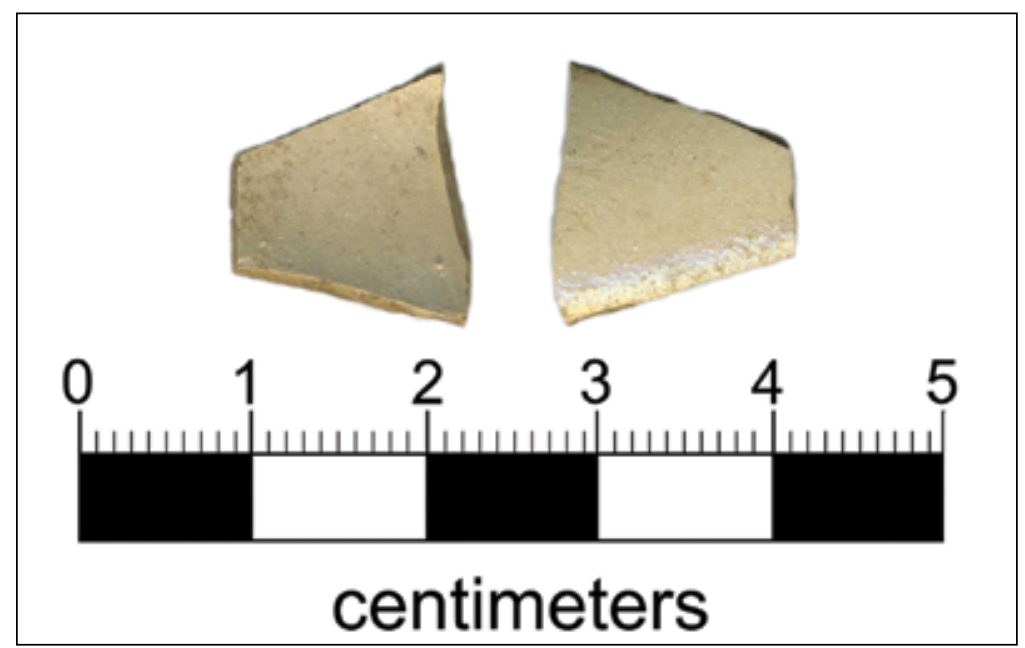

Figure 11. Salt-glazed stoneware sherd from 41RK66. Provenience: Unit 387, 0-10 cm bs. collections, and the excavation of $3750-$ $x-50-\mathrm{cm}$ units in an area southwest of the main house feature (Davis et al. 1994). During the excavations, in addition to the recovery of a large assemblage of late-nineteenth to mid-twentieth century artifacts, three features were documented, including a 3-x-5-m trash pit (Feature 1), a possible posthole (Feature 2), and another but less well-documented trash pit (Feature 3) (Davis et al. 1994:34-35). Artifacts found in the excavations were predominately domestic items, especially culinary glass, tin cans, ceramics, and wire and cut nails. The proportion of cut to wire nails (77.6 percent cut) suggests the main period of use occurred around 1888-1889 (Adams 2002:Table 3).

Davis et al. (1994:68) recommended additional investigation at the site if it were to be threatened by future developments. Since there have been no threats to the site since that time, no additional archeological investigations have been undertaken at the J. M. Robertson House site.

During the 2010 archeological investigations at the Park, no work was conducted at this site other than to photograph its current condition. The J. M. Robertson House is in a fenced thicket of brush and vines, and it appears undisturbed. The historic house foundation feature area (see Davis et al. 1994:Figure 4) is still visible in the fenced thicket because of vegetation typically found around abandoned historic farmsteads in East Texas, including chinaberry, bois d'arc, crepe myrtle, wild roses, and honeysuckle.

\section{$41 R K 69$}

When 41RK69 was first recorded in 1973 (Clark and Ivey 1974), this historic farmstead site had visible remnants of a pier foundation (brick and hematite stones) of a farmhouse and an associated artifact scatter of refined earthenwares, stoneware sherds, glass, a cast iron teapot, an iron hoe blade, and a metal skillet. The site was located on an upland slope (330-340 ft amsl) about $130 \mathrm{~m}$ east of an unnamed tributary to Rocky Ford Creek (see Appendices 1 and 3).

When the site was revisited in 2010 during the current archeological survey, the remnants of the farmhouse were marked by a 2.4-m-long $\times 0.8-\mathrm{m}$-wide pile of hand-made bricks (likely the location of an old chimney base, although the pile had been disturbed by a large tree growing through it) near the center 
of the site (Figure 12). However, no hematite rocks as mentioned by Clark and Ivey (1974) were identified. The brick pile stood approximately $30 \mathrm{~cm}$ above the ground surface, and there were at least two layers of buried brick associated with the brick pile. The one whole hand-made brick was reddish-brown (2.5YR 4/4) in color, and measured $8.5 \times 4.5 \times 2.75$ inches in length, width, and thickness, respectively.

The site is in a pine-hardwood forest with a thick understory of briars, bushes, and vines; surface visibility was less than 10 percent. A concentration of cast iron stove parts was present about $5 \mathrm{~m}$ west of the brick pile (in the area of ST 318). The site is located just south of the faint traces of an old roadbed (see Figure 12).

Of the shovel tests excavated in the site area, six of them contained historic archeological deposits (see Figure 12). 4lRK69 covers an area of approximately $900 \mathrm{~m}^{2}$ (0.2 acres).

Two 50- $\times-50-\mathrm{cm}$ units were excavated at 41RK69, primarily because the archeological deposits at the site are so shallow, and it was felt that an additional 50-x-50-cm unit could obtain a more representative sample of the artifacts present in the site's archeological deposits. Unit 390 was $40 \mathrm{~cm}$ south of ST 333 in the southeastern part of the site (see Figure 12). Historic artifacts were found at $0-8 \mathrm{~cm}$ bs in Zone 1 sediments (see Figure 10b); the underlying subsoil is a red (2.5YR 4/6) clay (Zone 4). The second 50- $\times-50-\mathrm{cm}$ unit (Unit 393) was located $11 \mathrm{~m}$ west and $9 \mathrm{~m}$ north of Unit 390 , and $30 \mathrm{~cm}$ south of ST 319. The archeological deposits (Zone 1) were somewhat thicker in this unit (0-12 cm bs) overlying a Zone 4 subsoil (see Figure 10c). In addition to historic nails, glass, and ceramics, brick fragments were found in Zone 1.

A total of 65 historic artifacts were recovered in the current archeological investigations at 41 RK69 (Table 6). This included 27 artifacts from the six positive shovel tests, and 38 artifacts from the two $50-\times-50-$ $\mathrm{cm}$ units ( $\mathrm{n}=13$ in Unit 390 and $n=25$ artifacts in Unit 393, near the center of the site). These artifacts were recovered from archeological deposits no more than $20 \mathrm{~cm}$ in thickness. The density of artifacts in the shovel testing was 4.5 per positive shovel test, or approximately 36 artifacts per $\mathrm{m}^{2}$. Densities in the two $50-x-50-\mathrm{cm}$ units ranged from 52 to 100 artifacts per $\mathrm{m}^{2}$, or 520-670 artifacts per $\mathrm{m}^{3}$ of archeological deposits.

The artifacts from 41RK69 are consistent with a farmstead occupation that would have primarily been occupied before 1880 (see Table 6). This interpretation is based on the proportion of cut to wire nails (94 percent cut nails, see Adams 2002:Table 3), the presence of brown lead-glazed stoneware that was popular in East Texas during approximately 1870-1900 (see Lebo 1987), and the occurrence of the porcelain shirt and collar buttons. The assemblage itself is dominated by cut nails used in the construction of a wood-framed structure that may have had a brick chimney base, along with cast iron stove parts, glass from snuff, medicinal, and alcoholic containers, and ceramic plates and stoneware crockery (Figure 13, see also Table 6).

\section{RK71, J. M. Griffin House}

The J. M. Griffin House site is the archeological remains of a 40-x-60-ft farmhouse (visible on a 1939 aerial photograph and as recorded in 1974), and an associated yard scatter of discarded artifacts. On the ground, when the foundation was first recorded in the early 1970s, it appeared to have been marked by piles of hematite blocks at the corners and along the walls. The site is on an upland slope (340-350 $\mathrm{ft}$ amsl) (see Appendices 1 and 3).

The site area is now in a thick brush-, briar-, and vine-covered area of the Park, with a pine and hardwood overstory. Surface visibility was less than 10 percent. The current archeological investigations 


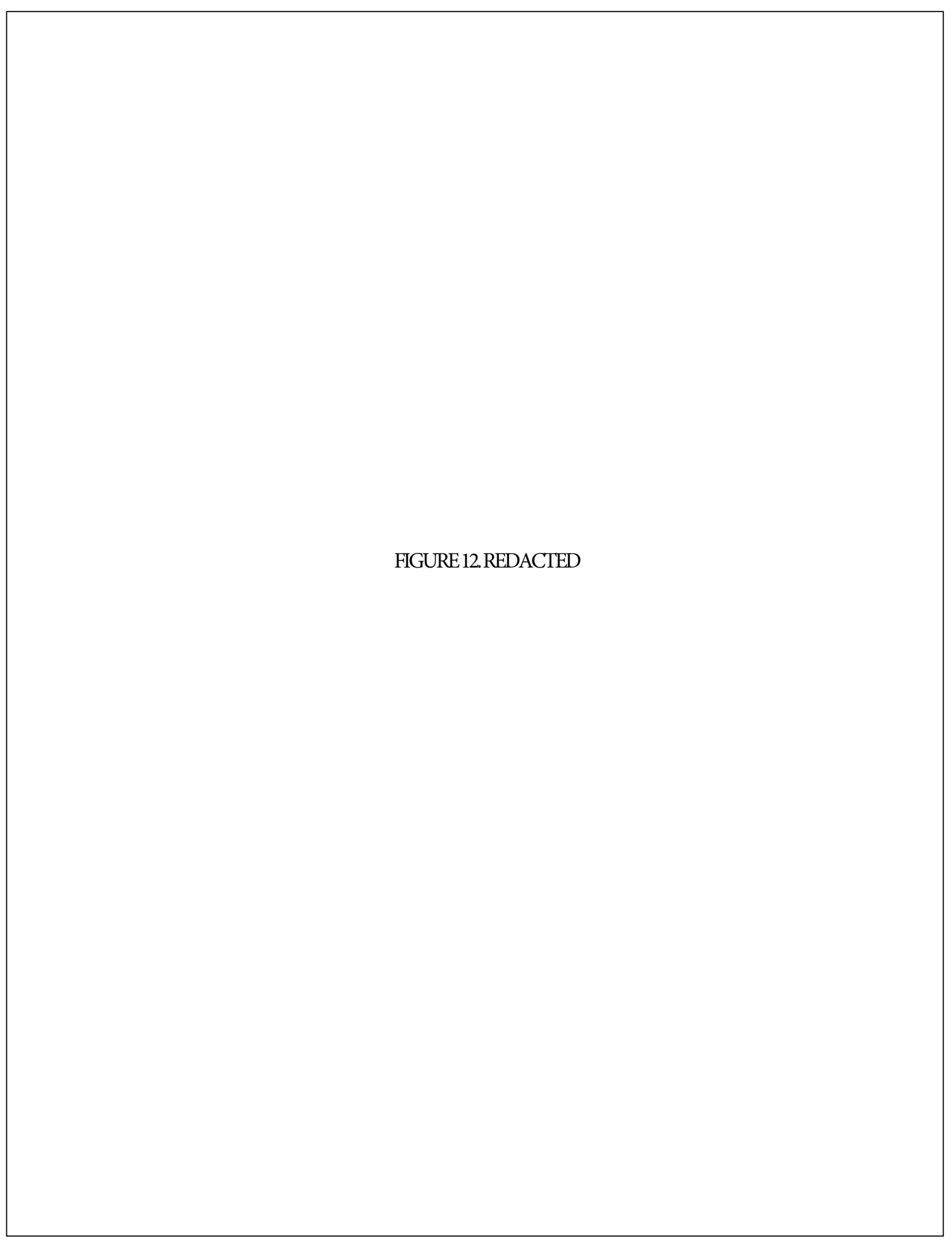

Figure 12. Map of 41 RK69. 
at the site documented the foundation as a rectangular pad or artificially raised house mound that is approximately $30-40 \mathrm{~cm}$ high and $7.3 \mathrm{~m}$ long by $5.5 \mathrm{~m}$ wide (Figure 14). Six sandstone footing stones markthe north wall of the house and a small part of the west wall; additional footing stones are either shallowly buried on the house mound, or have been displaced by previous tree clearing activities. There is also a hand-dug and unlined well (1.5-m diameter) approximately $10 \mathrm{~m}$ west-northwest of the northwest corner of the house foundation; it is currently $140 \mathrm{~cm}$ in depth.

Table 6. Historic artifacts from 41 RK69.

\begin{tabular}{lcl}
\hline \multicolumn{1}{c}{ Artifact Category } & No. & \multicolumn{1}{c}{ Comments } \\
\hline porcelain buttons & 2 & $\begin{array}{l}\text { ca. 1850-1910, 4-holed shirt } \\
\text { and collar button }\end{array}$ \\
brown bottle glass sherds & 5 & \\
clear bottle glass sherds & 4 & includes medicinal vial \\
aqua bottle glass sherds & 1 & \\
amber glass sherds & 3 & snuff bottle \\
yellow glass sherds & 1 & base to a pitcher? \\
plain whiteware sherds & 4 & \\
plain ironstone sherds & 1 & \\
plain porcelain sherds & 2 & \\
brown stoneware sherd & 1 & mid-late nineteenth century \\
& & (Lebo 1987; Greer 1981) \\
white milk glass sherd & 1 & \\
hand-made brick fragments & 3 & \\
machine-made brick fragments & 1 & post-1891 (Wells 2000) \\
cut nails & 16 & \\
wire nails & 1 & \\
unidentified nail shank & 7 & \\
cast iron stove fragments & 9 & \\
iron rod and bolt & 1 & \\
iron hook & 1 & \\
iron wheel and attached leg & 1 & \\
\hline
\end{tabular}

Five shovel tests excavated in and around the house foundation contain historic archeological materials in 40-cm-thick sandy loam deposits. The J. M. Griffin House site covers an estimated $900 \mathrm{~m}^{2}(0.2$ acres). Unit 382 (50-x-50-cm unit) is $70 \mathrm{~cm}$ west of ST 376 (see Figure 14). Historic archeological materials occur at 0-30 $\mathrm{cm}$ bs, in Zone 1 and 2 sandy loam deposits (see Figure 10d). These deposits are a maximum of $41 \mathrm{~cm}$ thick overlying Zone 4 and Zone 5 (strong brown clay, 7.5YR 5/8) subsoil sediments.

A total of 28 historic artifacts (including several pieces of extremely rusted iron fragments) have been recovered from the site during shovel testing $(n=18$, from five shovel tests) and $50-x-50-\mathrm{cm}$ unit excavations ( $n=10$ ). In the shovel testing, the artifacts occur at $0-40 \mathrm{~cm}$ bs, but are only found at depths of $0-30 \mathrm{~cm}$ in Unit 382 . The density of artifacts in the positive shovel tests is 3.6 , or approximately 28.8 artifacts per $\mathrm{m}^{2}$. In 
Unit 382 , the artifact density is 40 per $\mathrm{m}^{2}$, and 133 per $\mathrm{m}^{3}$.

The historic artifacts from the J. M. Griffin House site are from an early twentieth century farmstead occupation (Table 7). There is evidence of food containers (cans and bottle glass) and food serving artifacts (a whiteware sherd likely from a plate) discarded at the site, along with house construction artifacts (wire nails) and window glass from a wood-framed structure.

The unidentified iron piece (see Table 7) is a circular-shaped fragment, likely from a farm tool or wagon hardware. The cupreous object is a small $(15.5 \times 13.5$

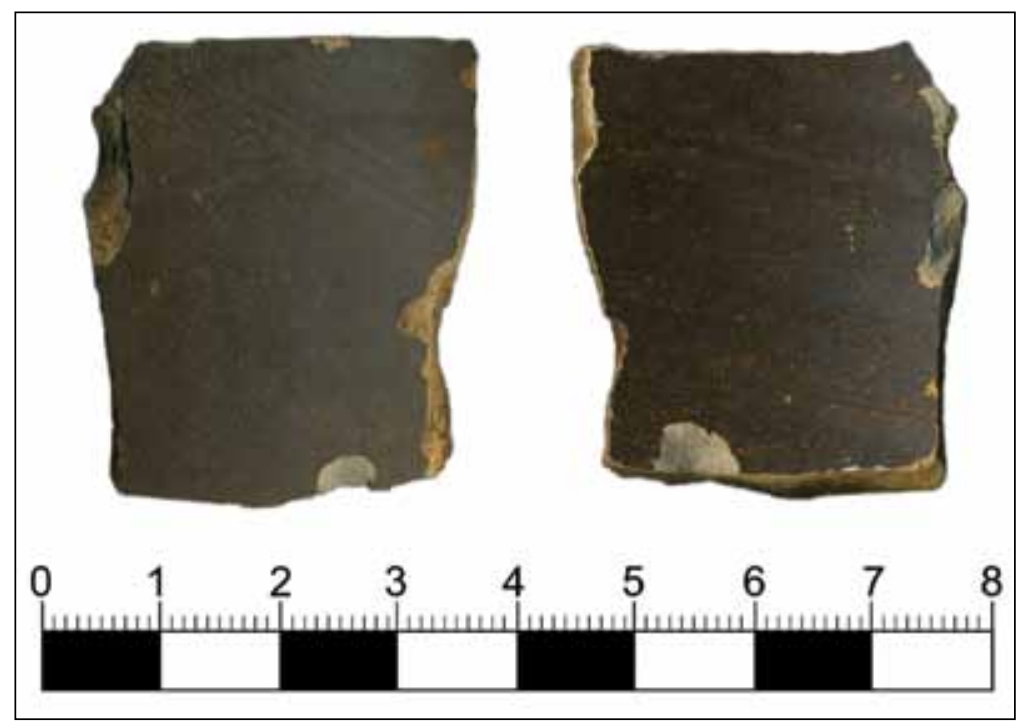

Figure 13. Brown lead-glazed stoneware from 41RK69. Provenience, ST 321, 0-20 cm bs. $\mathrm{mm}$ ) and thin rectangular-shaped piece with two small holes for attachment at one end of the piece.

Table 7. Historic artifacts recovered from the J. M. Griffin House (41 RK71).

\begin{tabular}{lrl}
\hline \multicolumn{1}{c}{ Artifact category } & No. & \multicolumn{1}{c}{ Comments } \\
\hline Metal can fragments & 15 & possible iron can \\
Wire nails & 6 & post-1891 (Wells 2000) \\
Plain whiteware sherds & 1 & \\
Aqua window glass & 1 & $2.5 \mathrm{~mm}$ thick, 1923.2 \pm 7 (Moir 1987, 1988) \\
Clear bottle glass sherds & 2 & \\
Blue-green glass sherds & 1 & \\
unidentified iron fragment & 1 & \\
unidentified cupreous object & 1 & \\
\hline
\end{tabular}

\section{RK133, Henderson Road Bridge}

This site is the remains of the Henderson Road Bridge ( $310 \mathrm{ft}$ amsl), once $20 \times 30 \mathrm{~m}$ in size, located on the Old Henderson Road where it crosses a small tributary stream of Rocky Ford Creek about $800 \mathrm{~m}$ west-southwest of the Harmony Hill Cemetery (see Appendices 1 and 3). The roadbed leading up to the bridge location was reported in 1983 to be approximately $4 \mathrm{~m}$ wide, with ditches on both sides. The bridge abutment was built with local hematite stones, probably in the mid-nineteenth century; it was apparently still in use in the 1930s.

In 2010 , not much remained of the bridge except for approximately 10 rocks from the bridge in the Rocky Ford Creek bed, and a similar number eroding out along the northwest side of the old bridge 
FIGURE 14. REDACTED

Figure 14. Map of the J. M. Griffin House (41RK71). 
crossing over the tributary stream. The old roadbed at the crossing is $1 \mathrm{~m}$ high, and $4 \mathrm{~m}$ wide where it would have crossed the stream.

\section{$41 R K 466$}

This prehistoric site of unknown age was reported as being situated on a narrow ridge ( $280 \mathrm{ft}$ amsl) that protrudes from an island in Martin Lake (see Appendices 1 and 3) when the lake is at conservation levels; this landform would have overlooked the Martin Creek floodplain before the lake was built. At normal or conservation pool water levels (306 ft amsl), 41RK466 would be under water. During 1996 investigations by Stephen F. Austin State University, six shovel tests were excavated at the site and a surface collection was performed. Only three pieces of lithic debris, four fire-cracked rocks, and a quartzite hammerstone were found over a $2500 \mathrm{~m}^{2}$ area ( 0.6 acres). The archeological deposit was estimated at no more than $85 \mathrm{~cm}$ in thickness from the modern surface (Becker 1996). Bo Nelson had visited 41 RK466 about five years ago when it was not submerged because of low water levels in the lake, and he noted 4-5 pieces of fire-cracked rock and two pieces of lithic debris on the surface at that time.

With the lake levels at $304.5 \mathrm{ft}$ amsl during the June 2010 archeological survey, $41 \mathrm{RK} 466$ was determined to be currently under approximately $20 \mathrm{ft}$ of water. The tops of several trees stick out of the lake about $100 \mathrm{~m}$ from the current shoreline of the island, and these likely mark the submerged ridge and archeological site. No pedestrian survey or shovel test investigations were conducted at the site in this project.

\section{RK467, Big Toe}

The Big Toe site is located on the Martin Lake shoreline, on an upland ridge (280-308 $\mathrm{ft}$ amsl) that projects into the lake (Figure 15). A small and intermittent tributary to Rocky Ford Creek (now under water) lies $30 \mathrm{~m}$ east of the ridge. The site, which was estimated to cover an area of $336 \mathrm{~m}^{2}$ when it was first recorded by Stephen F. Austin State University, has both prehistoric and historic occupations. The prehistoric component consists of quartzite and chert lithic debris, a large quartzite cobble, and a fire-cracked rock. The historic artifacts from the site include domestic and architectural debris: brick, pieces of metal, ceramic sherds, and canning jars and jar lids. A concentration of brick, a concrete pylon, and scattered rocks are present along the southern part of the ridge at the shoreline and may mark the location of a house at the Big Toe site (Becker and Roberts 1996).

Shovel testing on the eastern tip of the landform in 2010 identified historic archeological deposits in five shovel tests that extend across an area covering approximately $700 \mathrm{~m}^{2}$ or approximately 0.2 acres (see Figure 15). The site area has an overstory of hardwoods and a thick understory of brush, vines, and button willow; surface visibility was less than 10 percent, even along the shoreline. An area of a few brick fragments was noted at the far southeastern part of the site, along the active shoreline.

The 50-x-50-cm unit (Unit 391) excavated at the Big Toe site in this investigation is $70 \mathrm{~cm}$ northwest of ST 8 (see Figure 15). It contained a relatively high density of historic artifacts (glass, asphalt shingle fragments, metal, and brick fragments) at $0-30 \mathrm{~cm}$ bs in Zone 1 and 2 sandy loam zones (see Figure 10e). The A- and E-horizon sandy loam sediments in the unit are a maximum of $60 \mathrm{~cm}$ thick (including Zones 1,2 , and 6, a yellowish-brown sandy loam with manganese concretions), overlying a red sandy clay (Zone 7). 
FIGURE 15. REDACTED

Figure 15. Map of the Big Toe site (41RK467). 
As expected from previous archeological findings, both prehistoric $(n=1)$ and historic $(n=164)$ artifacts have been recovered in the archeological investigations at 4 lRK467 (Table 8), although historic artifacts greatly outnumber the prehistoric artifacts by a ratio of 164:1. The density of historic artifacts in the shovel testing (based on five positive shovel tests) was 8.8 per positive shovel test, or approximately 70.4 artifacts per $\mathrm{m}^{2}$. In the $50-\times-50-\mathrm{cm}$ unit, the density of historic artifacts was a very high 480 per $\mathrm{m}^{2}$, and 1600 artifacts per $\mathrm{m}^{3}$.

Table 8. Historic artifacts from 41 RK467.

\begin{tabular}{lrl}
\hline \multicolumn{1}{c}{ Artifact Category } & No. & \multicolumn{1}{c}{ Comments } \\
\hline hard rubber button & 1 & post-1870 (Meissner 1997) \\
clear bottle glass sherd & 90 & \\
green jar glass sherd & 2 & \\
aqua bottle glass sherd & 1 & \\
amber glass sherds & 1 & snuff container \\
clear fruit jar glass & 9 & \\
green fruit jar glass sherds & 1 & \\
white milk glass lid liner & 3 & \\
sherds & & \\
aqua tableware glass sherds & 1 & \\
clear tableware glass sherds & 2 & \\
aqua window glass & 4 & $2.0-2.5$ mm thick, 1881.1 \pm 7 \\
& & to 1923.2 \pm 7 \\
clear window glass & 9 & $1.7-2.5$ mm thick, 1855.9 \pm 7 \\
& & (Moir 1987, 1988) \\
unidentified nail shank & 6 & \\
hand-made brick fragments & 2 & \\
unidentifiable metal & 11 & \\
fragments & & 1
\end{tabular}

With the exception of a few pieces of relatively thin window glass that may have been manufactured in the 1850s and 1860s, the historic artifacts from 41RK467 are from a farmstead occupation dated from approximately 1870 to the 1920 s or later (see Table 8). The presence of the post-1870 4-hole hard rubber button is consistent with this interpretation (Figure 16).

A wood-framed structure stood on the site (probably located in the area of Unit 391) with windows and an asphalt shingle roof. Bottle glass $(n=91)$, glass snuff $(n=1)$, glass tableware $(n=3)$, glass jar $(n=2)$, and canning fruit jar glass and milk glass lid liner $(n=13)$ sherds dominate the artifact assemblage, accounting for 67 percent of the recovered sample. The bottle glass pieces are from post-1905 automatic bottle making machines, and the bright green jar glass may have been made by Owens-Illinois Co. around 1940 (Society 
for Historical Archaeology 2010). The glass fruit jars have continuous screw thread finishes, and are likely from Mason's Patent closure jars, first patented in 1858 , and manufactured until approximately 1915 (Society for Historical Archaeology 2010), as well as early to mid-twentieth century Ball Perfect Mason jars. Curiously, no whiteware or stoneware sherds were recovered.

Embossed marks are visible on several of the clear bottle glass sherds, including "MO..." and "... OROLINE". The clear bottle glass sherd with the

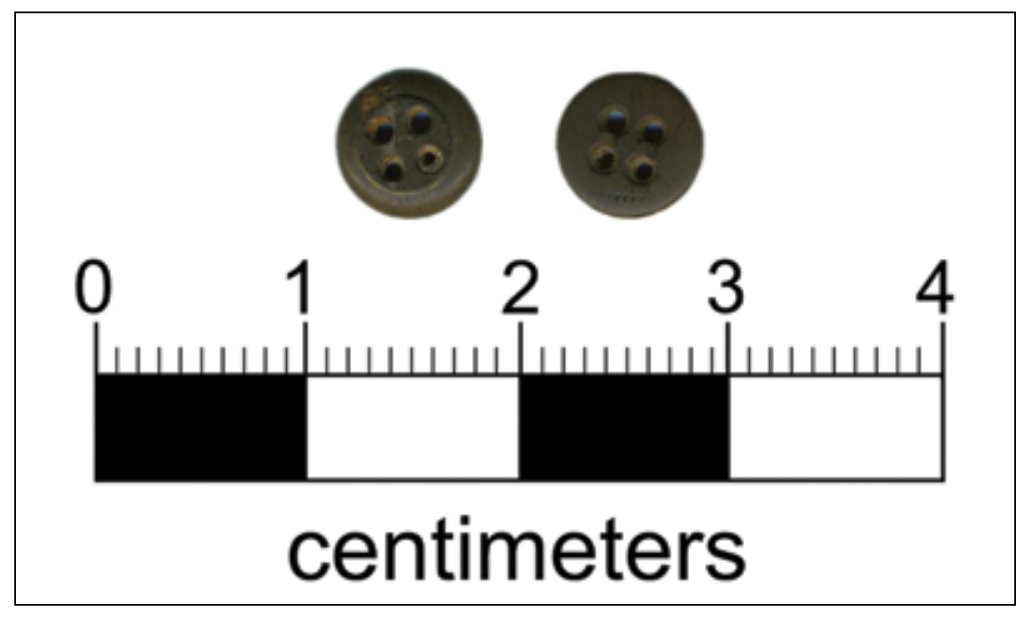

Figure 16. Hard rubber button from 41 RK467. Provenience, ST 8, 0-20 cm bs.

“... OROLINE" embossed mark is from a

paneled medicinal/chemical/druggist bottle likely made in the 1870s and 1880s, based on the bottle shape and the embossing marks (Society for Historical Archaeology 2010). Fruit jar glass sherds have "Ball" and "Quart" embossed marks.

A single Late Archaic (ca. 5000-2500 B.P.) dart point stem fragment was recovered in ST 2 at $20-40 \mathrm{~cm}$ bs. It is made from a local petrified wood and has a slight expanding stem and a flat base (with a smoothed cortex on the piece). The stem is $5.1 \mathrm{~mm}$ thick and $11.3 \mathrm{~mm}$ wide.

\section{Investigations at Newly Recorded Sites}

\section{Site \#1 (41RK605)}

This site is on an upland landform not far from the current Martin Creek Lake shoreline (304.5-308 $\mathrm{ft}$ amsl). Developed campsites are present in the area (\#9 and \#10 in the Broken Bowl Camping area), as well as a paved Park road (Figure 17). Between the two sections of the paved Park road is an area that has been graded by heavy machinery to form a drainage ditch. The site area itself is covered in thick brush and vines as well as hardwoods; surface visibility was less than 10 percent. Shovel tests were excavated along the ridge paralleling the lake shoreline, but only two of them (ST 12 and ST 34) contained prehistoric archeological materials in relatively deep A- and E-horizon sandy loam deposits. Site size is estimated at less than $100 \mathrm{~m}^{2}$.

Unit 392 (a 50-x-50-cm unit) is $2.1 \mathrm{~m}$ northeast of ST 38 (see Figure 17). It was excavated to $100 \mathrm{~cm}$ bs, but did not contain any artifacts. The sediments in the unit (see Figure 10f) include $75 \mathrm{~cm}$ of $\mathrm{A}$ - and E-horizon sandy loam zones, including Zone 1, 2, and 8 (a yellowish-brown sandy loam with strong brown mottles overlying a strong brown loam) that extends from $75 \mathrm{~cm}$ to $100 \mathrm{~cm}$ or more.

This prehistoric site has a very low density of lithic artifacts recovered in deposits between 20-40 and 80-100 cm bs. Two positive shovel tests each had one piece of lithic debris: a non-cortical flake fragment of gray chert (ST $34,20-40 \mathrm{~cm}$ bs) and a non-cortical piece of petrified wood (ST 12, 80-100 cm bs). The 
FIGURE 17. REDACTED

Figure 17. Map of 41 RK605. 
density of artifacts in the positive shovel tests is 1.0 , or only approximately 8 artifacts per $\mathrm{m}^{2}$. As previously mentioned, the $50-x-50-\mathrm{cm}$ unit did not contain any prehistoric artifacts.

\section{Site \#2 (41RK606)}

This site is located on an upland toe slope (320-330 ft amsl) in the western part of the Park, just $20 \mathrm{~m}$ south of the Old Henderson Road (Figure 18). Several Park trails cross the site. An intermittent tributary to Rocky Ford Creek lies about $100 \mathrm{~m}$ east of the site. The site area has an overstory of pine and hardwoods, with a thick understory of brush and vines; surface visibility was less than 10 percent.

Six shovel tests dispersed across the landform contain archeological materials, but no structural remains or features were discernible from surface evidence or in the subsequent subsurface archeological investigations. Site size is estimated at $3000 \mathrm{~m}^{2}$ (ca. 0.75 acres). The $50-x-50-\mathrm{cm}$ unit (Unit 389) excavated at this site is $40 \mathrm{~cm}$ north of ST 111 (see Figure 18). It has historic artifacts at a depth of $0-30 \mathrm{~cm}$ bs in Zone 1 and 2 sandy loam deposits, overlying a Zone 4 red clay (see Figure 10g).

Both prehistoric $(n=1$, from ST $111,20-40 \mathrm{~cm}$ bs) and historic $(n=18)$ artifacts were recovered in six shovel tests and one $50-x-50-\mathrm{cm}$ unit at this site. The density of prehistoric artifacts was 1.0 per positive shovel test (ca. 8 artifacts per $\mathrm{m}^{2}$ ), while the historic artifact density in the shovel tests was 1.50 per positive shovel test (ca. 12.0 artifacts per $\mathrm{m}^{2}$ ). In the $50-\times-50-\mathrm{cm}$ unit, the density of historic artifacts was greater at 36 per $\mathrm{m}^{2}$, the equivalent of 120 artifacts per $\mathrm{m}^{3}$.

The one prehistoric artifact was a non-cortical piece of heat-treated quartzite lithic debris. Quartzite is a locally available lithic resource for stone tool knapping, and the archeological evidence from these investigations suggests that only occasional stone tool knapping was done here by prehistoric peoples.

The historic artifacts from the site (Table 9) suggest a domestic occupation or farmstead was present here between as early as 1860 and the early twentieth century. There is evidence that a brick chimney may have been built to accompany a wood-framed building with windows, and sherds were present from ceramic and glass plates and bottles used for food serving and as containers for liquids. One blue-green glass sherd may be from a medicinal container made in the late nineteenth or early twentieth century (Society for Historical Archaeology 2010).

Table 9. Historic artifacts from 41 RK606.

\begin{tabular}{lcl}
\hline \multicolumn{1}{c}{ Artifact Category } & No. & \multicolumn{1}{c}{ Comments } \\
\hline hand-made brick fragments & 5 & \\
purple bottle glass & 1 & $1880-1918$ (Newman 1970) \\
aqua bottle glass & 1 & \\
clear bottle glass & 3 & \\
blue bottle glass sherd & 1 & Medicinal? \\
clear glass sherd & 1 & not from a bottle \\
plain ironstone sherds & 2 & \\
plain whiteware sherds & 2 & \\
aqua window glass sherd & 1 & 1.78 mm thick, 1862.6 \pm 7 (Moir 1987, 1988) \\
unidentifiable nail shanks & 1 & \\
\hline
\end{tabular}


FIGURE 18. REDACTED

Figure 18. Map of 41RK606. 


\section{Site \#3 (41RK607)}

This multicomponent site is on an upland toe slope (310 ft amsl) in the northeastern part of the Park (see Appendix 3), along the eastern boundary fence line. The site has a thick understory of brush and vines, with a mature pine overstory; surface visibility was less than 10 percent. A cleaned-out spring (4 $\mathrm{m}$ in diameter) is present about $15 \mathrm{~m}$ south of the southern boundary of the site (Figure 19). The eastern boundary of the site is marked by a 3-4 m heavy machinery-created cut bank paralleling a roadbed and the wire fence line of the TPWD Park boundary. Seven shovel tests were excavated in or in the immediate vicinity of the defined site boundaries, and the four positive shovel tests define a site area of approximately $800 \mathrm{~m}^{2}$ (0.2 acres).

Unit 388, the 50-x-50-cm unit, is $50 \mathrm{~cm}$ west of ST 158 (see Figure 19), in the western part of the site. This unit has historic archeological deposits that are a maximum of $40 \mathrm{~cm}$ thick in Zone 2 sandy loam sediments. The top of the yellowish-brown sandy clay (Zone 10) is at approximately $52 \mathrm{~cm}$ bs (see Figure 10h). No historic structural remains or features were visible on the surface at $41 \mathrm{RK} 607$, and none were encountered in the shovel testing or in the 50- $\times-50-\mathrm{cm}$ excavation unit.

The small assemblage from 41 RK607 contained both prehistoric $(n=1)$ and historic $(n=25)$ artifacts. The one prehistoric artifact (a Scallorn arrow point, see below) was found at $20-30 \mathrm{~cm}$ bs in Unit 388 . The historic artifacts occurred in 0-40 cm thick archeological deposits in four shovel tests and Unit 388 . The density of historic artifacts was 3.50 per positive shovel test, or approximately 28.0 artifacts per $\mathrm{m}^{2}$. In Unit 388 , the density of artifacts was 44 per $\mathrm{m}^{2}$, and there were 110 artifacts per $\mathrm{m}^{3}$ of archeological deposits.

The historic occupation at 41RK607 may predate 1870, except for the one wire nail (post-1891) from ST 158 (Table 10). This interpretation is based on the presence of pre-1870 olive and dark olive green bottle glass sherds (from wine, whiskey, or brandy bottles) (Newman 1970:72-74; Society for Historical Archaeology 2010), the 1840s-1860s hand-painted and hand-painted annular whiteware sherds (Majewski and O'Brien 1987), the frequency of cut nails (Figure 20b), and a ca. post-1850 porcelain four-hole shirt/ dress button. These kinds of buttons remained popular until the early twentieth century (Meissner 1997:120).

The range of historic artifacts suggests that they are discarded refuse and structural debris from a nineteenth century farmstead. The hand-made brick fragments and nails indicate that a wood-framed structure stood on the site, probably with a brick chimney or a brick base to a mud cat chimney (see Jordan 1978). The occupants of the site used and discarded food/liquid containers and food serving dishes, and lost at least one clothing button during the occupation.

The Scallorn arrow point (see Figure 20a) was made from a local red chert and has been bifacially flaked to shape, with pressure flakes along the margins to complete the point. It has an expanding stem and corner notches, as well as a resharpened blade. The point is $11.9 \mathrm{~mm}$ long, $11.5 \mathrm{~mm}$ wide, $2.8 \mathrm{~mm}$ thick, and has a 5.1-mm stem width. In East Texas, Scallorn points are typically seen in Late Woodland (ca. A.D. 700850) and Early Caddo (ca. A.D. 850-1000) archeological sites. 
FIGURE 19. REDACTED

Figure 19. Map of 41 RK607. 
Table 10. Historic artifacts from 41 RK607.

\begin{tabular}{lcl}
\hline \multicolumn{1}{c}{ Artifact Category } & No. & \multicolumn{1}{c}{ Comments } \\
\hline hand-made brick fragments & 3 & \\
wire nails & 1 & post-1891 (see Wells 2000) \\
cut nail & 3 & $1820-1891$ (see Wells 2000) \\
unidentifiable nail shanks & 2 & \\
hand-painted whiteware sherd & 1 & 1840 s-1860s \\
hand-painted annular whiteware & 1 & 1840 s-1860s (Majewski and O'Brien 1987) \\
sherds & & \\
plain whiteware sherds & 1 & \\
aqua bottle glass sherds & 3 & \\
olive green bottle glass & 2 & pre-1870 bottle \\
dark olive green bottle glass & 1 & pre-1870 wine bottle \\
clear bottle glass sherds & 2 & \\
porcelain button & 1 & ca. 1850-1910 \\
unidentifiable metal fragments & 4 & \\
\hline
\end{tabular}

\section{Old Henderson Road (41RK608)}

Two segments (750 $\mathrm{m}$ in total length) of the Old Henderson Road, otherwise known as the Board Ferry Road (through the community of Harmony Hill and on to Henderson, Texas) or the Henderson-Shreveport Road (east to Shreveport, Louisiana, on the Red River), are present in the Park (see Appendix 3) where the road runs generally east-west across Park lands, crossing wooded upland slopes and small creek valleys (304-340 ft amsl). The road is marked by prominent and deep roadcuts (1-3 m deep). In some places multiple, parallel, routes are visible. Some sections of the old road are 20-30 $\mathrm{m}$ in width, but generally speaking the road is $4-5 \mathrm{~m}$ wide, with ditches on both sides.

The western segment of the road, which enters the Park near 4lRK133 and ends $560 \mathrm{~m}$ to the west in Martin Lake, has cut down 1-4 $\mathrm{m}$ into the landforms it crosses, and is parallelled by drainage ditches. A Park trail runs along this part of the old roadbed. The eastern segment of the road in the Park, which was covered

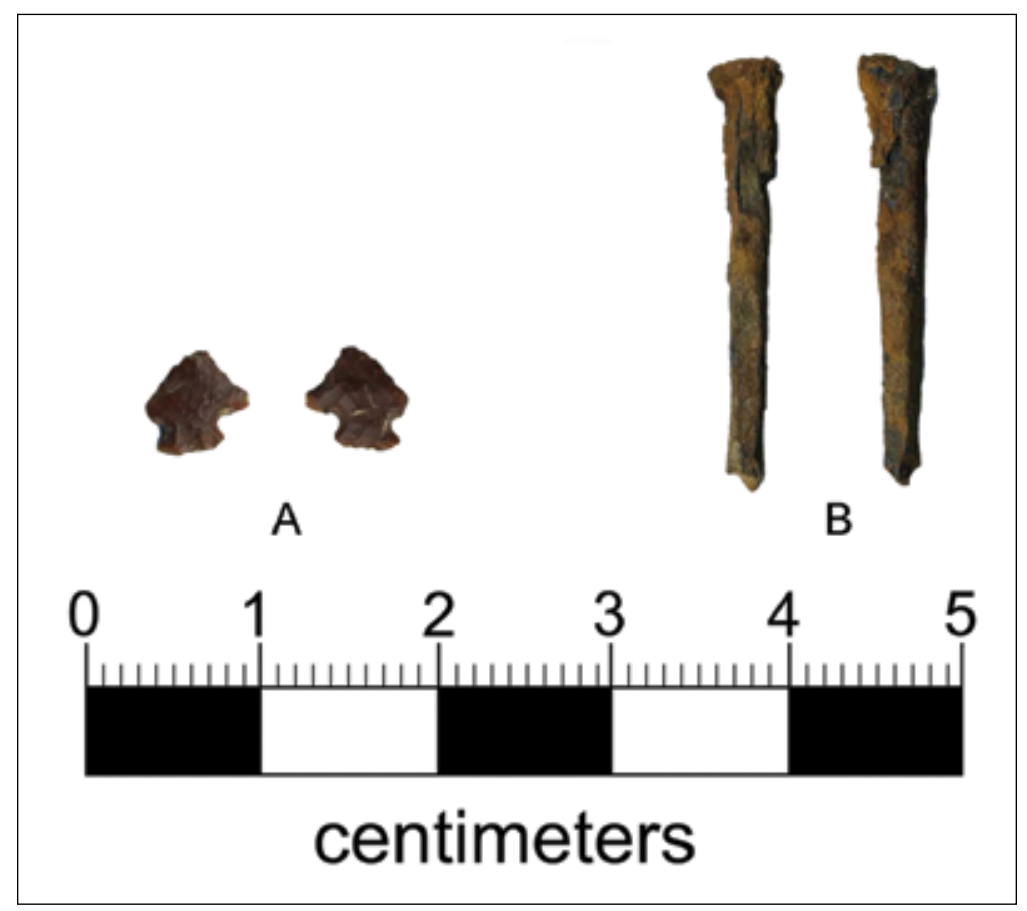

Figure 20. Selected artifacts from 41RK607: (a) Scallorn arrow point; (b) cut nail. Provenience: (a) Unit 388, 20-30 cm bs; (b) ST 161, $20-40 \mathrm{~cm}$ bs. 
by a thick cover of brush and vines, is approximately $190 \mathrm{~m}$ in length and runs along the northeast Park boundary (see Appendix 3).

\section{Isolated Find}

A single piece of prehistoric lithic debris was recovered at $20-40 \mathrm{~cm}$ bs in ST 229 in a defined high probability area in the far southeastern part of the Park (see Figure 4). The find location is on a natural rise that is approximately $20-30-\mathrm{m}$ wide by 50-60-m long and approximately $2 \mathrm{~m}$ above the lake shoreline; the landform is covered with pine and hardwood, with a thick understory of brush and vines. A Park trail crosses the rise.

Numerous other shovel tests on the rise failed to recover any additional prehistoric artifacts. The recovered artifact from the isolated find is a non-cortical gray chert flake fragment; it came from a heattreated pebble or cobble. It has been treated as an isolated find because the shovel tests excavated in each cardinal direction from the shovel test did not contain any prehistoric archeological deposits. 


\section{Chapter 7}

\section{Management Recommendations}

\section{State Archeological Landmark Eligibility}

The criteria for evaluating archeological sites as State Archeological Landmarks (SALs) are listed in Chapter 26.8 of the General Rules of Practice and Procedure (Chapter 26) for the Antiquities Code of Texas:

(1) the site has the potential to contribute to a better understanding of the prehistory and/or history of Texas by the addition of new and important information;

(2) the site's archeological deposits and the artifacts within the site are preserved and intact, thereby supporting the research potential or preservation interests of the site;

(3) the site possesses unique or rare attributes concerning Texas prehistory and/or history;

(4) the study of the site offers the opportunity to test theories and methods of preservation, thereby contributing to new scientific knowledge; and

(5) the high likelihood that vandalism and relic collecting has occurred or could occur, and official landmark designation is needed to insure maximum legal protection, or alternatively further investigations are needed to mitigate the effects of vandalism and relic collecting when the site cannot be protected.

Although all archeological sites in Martin Creek Lake State Park are de facto State Archeological Landmarks according to Section 191.092 of the Antiquities Code of Texas, a smaller number may warrant official designation after their research potential has been evaluated according to the above-mentioned criteria. Consideration of the SAL eligibility of the 13 known archeological sites at Martin Creek Lake State Park is based on Chapter 26.8(1-4), and the determinations in this report have been made in cognizance of the possibility that the Texas Historical Commission and TPWD may also make determinations as to whether or not these site warrant designation under Chapter 26.8(5). With respect to archeological resources, to have "intact" and preserved archeological deposits means that, at the survey level of investigation, (1) such deposits have the potential for features to be present, and/or features have been identified; (2) there exists, or the potential exists, for intra-site patterning in artifacts and features; and (3) representative samples of artifacts and/or features are present from undisturbed contexts from specific site assemblages and deposits.

In the present set of sites at Martin Creek Lake State Park, criteria 1 and 2 above are the most relevant because they specifically address the important contributions the sites can make to understanding the history and prehistory of Rusk County and East Texas. These criteria are also readily employed in site evaluations that are based on the sort of minimal data obtained from archeological sites identified and documented only through pedestrian survey, shovel testing, and $50-x-50-\mathrm{cm}$ unit excavations.

In many cases, the eligibility of particular sites for SAL designation cannot be determined with current limited archeological information because it is not possible to demonstrate with data derived from surface survey, shovel testing, and $50-\times-50-\mathrm{cm}$ test excavation units that the sites have, or had, information that can contribute to our understanding of human history or prehistory (pre-A.D. 1680) in the region. Without definitive demonstration of research potential, which is difficult to achieve with archeological sites known 
only from survey-level investigations, it is possible only to conclude that their SAL status is undetermined. Summaries of the sites known and/or found within the Park on the 2010 archeological survey, and assessments of their SAL eligibility, are presented in Table 11.

Table 11. Site Summaries and State Archeological Landmark recommendations, Martin Creek Lake State Park.

\begin{tabular}{|c|c|c|c|c|c|}
\hline Site No. & Age & Site Size $\left(\mathrm{m}^{2}\right)$ & $\begin{array}{c}\text { ST Artifact } \\
\text { Density (per } \\
\text { PST) }\end{array}$ & $\begin{array}{c}\text { 50- } \times-50- \\
\text { cm Artifact } \\
\text { Density (per } \\
\mathrm{m}^{2} \text { ) }\end{array}$ & Recommendations \\
\hline $\mathrm{RK} 9$ & $\begin{array}{l}\text { mid-nineteenth century.; } \\
\text { Prehistoric Caddo }\end{array}$ & UNK & UNK & UNK & $\begin{array}{l}\text { Not relocated; no } \\
\text { further work; not } \\
\text { recommended for } \\
\text { SAL status }\end{array}$ \\
\hline RK43 & early twentieth century & UNK & UNK & UNK & $\begin{array}{l}\text { Not relocated; no } \\
\text { further work; not } \\
\text { recommended for } \\
\text { SAL status }\end{array}$ \\
\hline RK66 & late $1800 s-1930 s$ & 2000 & 3.71 & 24 & $\begin{array}{l}\text { Undetermined; SAL } \\
\text { evaluation needed }\end{array}$ \\
\hline RK67 & $\begin{array}{l}\text { late nineteenth-mid- } \\
\text { twentieth centuries }\end{array}$ & 5800 & $\mathrm{~N} / \mathrm{A}$ & 105 & $\begin{array}{l}\text { SAL designation } \\
\text { (criteria } 1 \text { and } 2 \text { ) }\end{array}$ \\
\hline RK69 & pre-1880 & 900 & 4.5 & 76 & $\begin{array}{l}\text { Undetermined; SAL } \\
\text { evaluation needed }\end{array}$ \\
\hline RK7 1 & early twentieth century & 900 & 3.6 & 40 & $\begin{array}{l}\text { Undetermined; SAL } \\
\text { evaluation needed }\end{array}$ \\
\hline RK133 & mid-1800s-1930s & $4 \times 4$ & $\mathrm{~N} / \mathrm{A}$ & N/A & $\begin{array}{l}\text { No further work; } \\
\text { not recommended } \\
\text { for SAL status }\end{array}$ \\
\hline RK466 & UID Prehistoric & UNK & UNK & UNK & $\begin{array}{l}\text { Not relocated; no } \\
\text { further work; not } \\
\text { recommended for } \\
\text { SAL status }\end{array}$ \\
\hline RK467 & $\begin{array}{l}\text { Late Archaic-1870s- } \\
\text { 1920s }\end{array}$ & 700 & 8.8 & 480 & $\begin{array}{l}\text { Undetermined; SAL } \\
\text { evaluation needed }\end{array}$ \\
\hline RK605 & UID Prehistoric & 100 & 1.0 & 0.0 & $\begin{array}{l}\text { No further work; } \\
\text { not recommended } \\
\text { for SAL status }\end{array}$ \\
\hline RK606 & $\begin{array}{l}\text { UID Prehistoric-1860s- } \\
\text { early twentieth century }\end{array}$ & 3000 & 1.5 & 36 & $\begin{array}{l}\text { Undetermined; SAL } \\
\text { evaluation needed }\end{array}$ \\
\hline RK607 & Woodland and pre-1870 & 800 & 3.5 & 44 & $\begin{array}{l}\text { Undetermined; SAL } \\
\text { evaluation needed }\end{array}$ \\
\hline RK608 & 1850s-1930s (?) & $\begin{array}{l}750 \mathrm{~m} \text { long } \times \\
4-5 \mathrm{~m} \text { wide }\end{array}$ & $\mathrm{N} / \mathrm{A}$ & N/A & $\begin{array}{l}\text { SAL designation } \\
\text { (criteria 3) }\end{array}$ \\
\hline
\end{tabular}

ST = shovel test; PST = positive shovel test; UNK = Unknown; $/$ A $=$ not available; $\mathrm{UID}=$ unidentified; $\mathrm{SAL}=$ State Archeological Landmark 
Two of the 13 sites, 41RK67 and 41RK608, have been determined to be eligible for SAL designation. Site 4lRK67 warrants SAL designation because it contains intact features and archeological deposits of mid-nineteenth to mid-twentieth century age (see Davis et al. 1994) from a farmstead associated with the ca. 1850-1900 town of Harmony Hill. As such, it contains information important to the history of this part of East Texas and qualifies for SAL designation under criteria 1 and 2. Sites such as 41RK67 contain evidence for structures, yard or trash middens, and an abundant material culture record that can be informative about its life history (cf. Beaudry 2004:254, 262), Anglo-American farmsteads (cf. Groover 2008), the early frontier settlement of the region, and cultural adaptations from the mid-nineteenth century to the mid-twentieth century. The archeological remains and features recovered and studied from 41RK67 provide "a window into the everyday lives of rural Americans" (De Cunzo 2005:117).

The Old Henderson Road (41RK608) is considered worthy of SAL consideration under criterion 3 of Chapter 28 of the General Rules of Practice and Procedure for the Antiquities Code of Texas. The site, which consists of remnants of the roadbed and roadcuts, meets this criterion because it represents a road that was an important route of commerce in this part of East Texas in the mid-to late nineteenth century, and it played a significant role in the settling of the Harmony Hill community in the early 1850s. Most of the historic archeological sites in Martin Creek Lake State Park were part of this now abandoned community.

Six sites are of undetermined SAL status, and they warrant further attention to establish their eligibility for SAL designation (see Table 11). The principal occupation at each of these sites was a farmstead that was associated with the nearby town of Harmony Hill, as well as with the Old Henderson Road (41RK608), an early route of commerce in this part of East Texas. Only further investigations, including the development of a test excavation research design, along with test excavations and archival research, will determine whether the historic and historic-prehistoric sites of undetermined SAL status at Martin Creek Lake State Park meet any of the criteria specified in Chapter 26.8 of the General Rules of Practice and Procedure for the Antiquities Code of Texas. The purpose of the test excavations would be to determine whether any of these sites have research significance, have the potential to contain important information about the midnineteenth and early twentieth century history of the rural Harmony Hill area, and can contribute important information about the changing lifestyles of small landowners in East Texas.

Five archeological sites listed in Table 11 are not recommended for SAL status. Three of the sites (41RK9, 4lRK43, and 4lRK466) were not relocated during the 2010 archeological survey: two of the sites (4lRK9 and 4lRK43) are presumed to have been destroyed during 1970s activities associated with the construction of Martin Lake and the early developments in Martin Creek Lake State Park. The third site is under water (4lRK466), and its archeological deposits (if they still remain) have probably been disturbed by lake erosion and water level fluctuations. Artifacts and plant and animal remains that may have been present in archeological deposits will have been subjected to the destructive effects of long-term submergence. Because none of these sites could be relocated, we have concluded that they have poor contextual integrity, lack intact archeological deposits, and have limited archeological research potential. These sites have no potential to contribute to a better understanding of the history or prehistory of East Texas, or add new and important information that would address pertinent research questions about the history and prehistory of the region. 


\section{Archeological Sensitivity Zones at Martin Creek Lake State Park}

Two areas of high archeological sensitivity have been defined at Martin Creek Lake State Park (Figure 21) on the basis of all previous and current archeological survey investigations at the Park.

The two different areas represent landforms and settings within the Park where historic and/or multicomponent historic and prehistoric sites are known to be particularly abundant. They are also areas where important or potentially important archeological sites (i.e., sites likely to contain research potential and have preserved and intact archeological deposits and associated artifacts) have been identified from past and current archeological investigations.

The remainder of Martin Creek Lake State Park is considered to have a low archeological sensitivity (see Figure 21).

Figure 21 , in conjunction with site-specific recommendations summarized above, as well as management priority rankings (see below), will assist the Texas Parks and Wildlife Department in making decisions about whether further archeological studies will be needed at Martin Creek Lake State Park prior to the initiation of future maintenance or construction activities. In general, in our opinion, the areas of low archeological sensitivity do not warrant further archeological considerations by Texas Parks and Wildlife, other than steps that should be taken in the case of the accidental discovery of archeological sites in those areas (see discussion in McNatt et al. 2001:193).

\section{Management Priority Rankings}

This section of the report presents our evaluations regarding the management priority for TPWD Park management personnel of each of the sites investigated in the Martin Creek Lake State Park. These evaluations include the following:

- an assessment of the relative management priority of each archeological site, ranked from 1 (high) to 4 (low);

- specific recommendations for the management of each archeological site regardless of its management priority; and

- an assessment of the need for any additional research not covered under the contract between CAS and TPWD, as suggested by the results of the investigations. Site evaluations will clearly articulate the basis for the evaluation, with particular reference to research potential and local archeological context.

These management priority rankings for each archeological site adhere to a four-part classification system (Table 12). Sites officially designated as State Archeological Landmarks (SAL) are given Management Priority 1 ranking, and sites recommended for SAL designation are ranked at Management Priority 2. These management priority rankings will enable TPWD to focus on these sites in efforts to avoid impacts to significant cultural resources. Sites whose SAL status is unknown are ranked at Management Priority 3, so that further archeological investigations can be directed to them if warranted. Sites not recommended for SAL status are ranked at Management Priority 4, and have the lowest TPWD priority for management and protection. 


\section{FIGURE 21. REDACTED}

Figure 21. Areas of High Archeological Sensitivity at Martin Creek Lake State Park. 
Table 12. Management priority rankings for archeological sites in Martin Creek Lake State Park.

\begin{tabular}{lc}
\hline \multicolumn{1}{c}{ Site No. } & Management Priority Ranking (1 to 4) \\
\hline $41 \mathrm{RK} 9$ & 4 \\
$41 \mathrm{RK} 43$ & 4 \\
$41 \mathrm{RK} 66$ & 3 \\
$41 \mathrm{RK} 67$ & 2 \\
$41 \mathrm{RK} 69$ & 3 \\
$41 \mathrm{RK} 71$ & 3 \\
$41 \mathrm{RK} 133$ & 4 \\
$41 \mathrm{RK} 466$ & 4 \\
$41 \mathrm{RK} 467$ & 3 \\
$41 \mathrm{RK} 605$ & 4 \\
$41 \mathrm{RK} 606$ & 3 \\
$41 \mathrm{RK} 607$ & 3 \\
$41 \mathrm{RK} 608$ & 4 \\
\hline
\end{tabular}

The records of the Texas Historical Commission (2010) currently indicate no archeological sites designated as SALs in Martin Creek Lake State Park, and thus there are no Management Priority Rank 1 sites in the Park (see Table 12). However, the J. M. Robertson site (41RK67) is considered a contributing member to the Harmony Hill National Register of Historic Places District. Previously recorded sites 41RK66 and 41RK71 are within the boundaries of this district, but are not currently listed as contributing members.

Of the 13 archeological sites known and recorded within the boundaries of Martin Creek Lake State Park, one site (41RK67) has a Management Priority Rank 2. Six others (41RK66, 69, 11, 467, 606, and 607) are assigned a Management Priority Rank 3, and the remaining six sites (41RK9, 43, 133, 466, 605, and 608) have a Management Priority Rank 4 (see Table 12).

The one site with Management Priority Rank 2 should be avoided and protected during future proposed development projects at the Park. If the site cannot be avoided and protected, a program of archeological data recovery/mitigation is recommended as the next step in minimizing the effects of any future proposed development projects at the Park on this SAL-eligible site. The six Management Priority Rank 3 sites should also be avoided and protected during future proposed development projects at the Park until their SAL status is determined. If they cannot be avoided and protected, a program of archeological test excavation (accompanied by detailed archival research) is recommended as the next step in formally evaluating their research potential under the Antiquities Code and the criteria laid out in the General Rules of Practice and Procedure, Chapter 26.8(1-4). The six Management Priority Rank 4 sites do not merit further archeological work. In the case of 41RK608-the remnants of the Old Henderson Road-it has been considered worthy of SAL consideration because it represents a road that was an important route of commerce in this part of East Texas in the mid-to late nineteenth century, and it played a significant role in the settling of the Harmony Hill community in the early 1850s (see above). Because its archeological physical expression in the Park has been documented, no additional archeological work is recommended for the old east and west road segments (see Appendix 3), and the Management Priority Rank 4 determination has been assigned. 


\section{Additional Research Needs}

Two additional research needs concerning the archeological resources at Martin Creek Lake State Park have been identified: (1) detailed archival research on sites in the Park associated with the mid- to late nineteenth century community of Harmony Hill; and (2) backhoe investigations in one locale within the Park.

\section{Archival Research}

Detailed archival research may be warranted on farmstead sites in the Park that are apparently associated with the nineteenth century community of Harmony Hill, including 41RK66, 41RK69, 41RK71, 41RK467, 41RK606, and 41RK607. The purpose of this research would be to identify the specific occupants and families who may have used the sites during the archeologically defined occupations, and to better understand the relative social position of the families and households that may have lived at the sites.

This proposed research would rely on the use of primary materials, particularly deed record and tax information (ad valorem tax records on microfilm at the Texas State Library and Archives) preserved at the Rusk County Clerk's office, Texas General Land Office, Texas State Library and Archives, and the Rusk County Depot Museum. Online resources (such as Heritage Quest ${ }^{\mathrm{TM}}$ Online) may also contain documentation pertinent to these historic archeological sites, including age, gender, marital status, numbers of children, etc. of individuals who may have lived within one of these households. Tax records, along with relevant U.S. Census population schedules, and probate records should provide information on the value of the real and personal property held by the various families and households during the site occupations.

\section{Backhoe Investigations}

Considering the general upland setting of Martin Creek Lake State Park, only one area within the Park was identified where potential artifact-bearing sediments more than $100 \mathrm{~cm}$ in depth are present (see Figure 8). About 2 percent of the more than 420 shovel tests excavated in the Park did not reach the sterile B-horizon clay subsoil or had more than $100 \mathrm{~cm}$ of A- and E-horizon sediments (see Table 4 and Appendix 2). This area occurs on a narrow upland ridge that parallels the Martin Lake shoreline and is in the vicinity of 41 RK605 (see Appendix 3).

Backhoe trench investigations may be warranted in this locale for two principal archeological reasons: (1) to ascertain and clarify the depth, thickness, and depositional context of deep sandy sediments that may contain deep artifact-bearing sediments; and (2) to prospect for other archeological sites that are deeply buried and have no near-surface expression. Backhoe trench investigations in this locale may also be warranted to contribute archeological and geoarcheological information from Martin Creek Lake State Park on the research issue of "whether prehistoric sites can occur in a primary context buried within the socalled sandy mantle" (Crawford and Nordt 2001:17; see also Lohse and Bousman 2006). Several competing models have been proposed to account for the origins of the sandy mantle deposits and explain the occurrence of archeological materials buried in them (Lohse and Bousman 2006:60-63). These alternatives have implications for interpreting the depositional integrity and research potential of sandy mantle sites, and bear on the likely research significance of any sandy mantle sites at Martin Creek Lake State Park. 



\section{References Cited}

Adams, W. H.

2002 Machine Cut Nails and Wire Nails: American Production and Use for Dating 19th-century and Early 20th-Century Sites. Historical Archaeology 36(4):66-88.

Ahr, S.W.

1999 A Summary Report on Archeological Investigations at 41CE326: A Late Caddo Burial Site Inadvertently Discovered along US 69 south of Rusk, Cherokee County, Texas. Draft report. Archeological Studies Program, Environmental Affairs Division, Texas Department of Transportation, Austin.

Anderson, D. G.

1996a Models of Paleoindian and Early Archaic Settlement in the Lower Southeast. In The Paleoindian and Early Archaic Southeast, edited by D. G. Anderson and K. E. Sassaman, pp. 29-57. University of Alabama Press, Tuscaloosa.

1996b Approaches to Modeling Regional Settlement in the Archaic Period Southeast. In The Archaeology of the Mid-Holocene Southeast, edited by K. E. Sassaman and D. G. Anderson, pp. 157-176. University Press of Florida, Gainesville.

Anderson, D. G., D.W. Stahle, and M. K. Cleaveland

1995 Paleoclimate and the Potential Food Resources of Mississippian Societies: A Case Study from the Savannah River Valley. American Antiquity 60(2):258-286.

Anderson, D. G., L. O'Steen, and K. E. Sassaman

1996 Environmental and Chronological Considerations. In The Paleoindian and Early Archaic Southeast, edited by D. G. Anderson and K. E. Sassaman, pp. 3-15. University of Alabama Press, Tuscaloosa.

Anderson, K. M.

1972 Prehistoric Settlement of the Upper Neches. Bulletin of the Texas Archeological Society 43:121-197.

Anderson, K. M., K. Gilmore, O. R. McCormick III, and E. P. Morenon

1974 Archaeological Investigations at Lake Palestine, Texas. Contributions in Anthropology No. 11. Department of Anthropology, Southern Methodist University, Dallas.

Arnold, J.

2007 Jeff Davis's Own Cavalry, Comanches, and the Battle for the Texas Frontier. Castle Books, Edison, New Jersey.

Banks, L. D.

1990 From Mountain Peaks to Alligator Stomachs: A Review of Lithic Sources in the Trans-Mississippi South, the Southern Plains, and Adjacent Southwest. Memoir \#4. Oklahoma Anthropological Society, Norman. 
Beaudry, M. C.

2004 Doing the Housework: New Approaches to the Archaeology of Households. In Household Chores and Household Choices: Theorizing the Domestic Sphere in Historical Archaeology, edited by K. S. Barile and J. C. Brandon, pp. 254-262. University of Alabama Press, Tuscaloosa.

Becker, D.

1996 “4lRK466," TexSite Site Survey Form. Texas Historical Commission Texas Archeological Sites Atlas (http://nueces.thc.state.tx.us), accessed April 20, 2010.

Becker, D. and L. Roberts

1996 “41RK467,” TexSite Site Survey Form. Texas Historical Commission Texas Archeological Sites Atlas (http://nueces.thc.state.tx.us), accessed April 20, 2010.

Benson, L. V., M. S. Berry, E. A. Jolie, J. D. Spangler, D. W. Stahle, and E. M. Hattori

2007 Possible impacts of early-1 1th-, middle-12th-, and late-13th-century droughts on western Native Americans and the Mississippian Cahokians. Quaternary Science Reviews 26:336-350.

Bever, M. R. and D. J. Meltzer

2007 Exploring Variation in Paleoindian Life Ways: The Third Revised Edition of the Texas Clovis Fluted Point Survey. Bulletin of the Texas Archeological Society 78:65-99.

Bousman, C. B.

1998 Paleoenvironmental Change in Central Texas: The Palynological Evidence. Plains Anthropologist 43(164):201-219.

Bousman, C. B., B. W. Baker, and A. C. Kerr

2004 Paleoindian Archeology in Texas. In The Prehistory of Texas, edited by T. K. Perttula, pp. 15-97. Texas A\&M University Press, College Station.

Brantley, W. F.

1975 A Collector's Guide to Ball Jars. Rosemary Humbert Martin, Muncie, Illinois.

Brown, D. O.

1998 Late Holocene Climates of North-Central Texas. Plains Anthropologist 43(164):157-172.

Bruseth, J. E.

1991 Hudnall-Pirtle (41RK4): An Early Caddoan Mound Complex in Northeast Texas. Caddoan Archeology Newsletter II(3):9-15.

1992 Artifacts of the de Soto Expedition: The Evidence from Texas. Bulletin of the Texas Archeological Society 63:67-97.

1998 The Development of Caddoan Polities along the Middle Red River Valley of Eastern Texas and Oklahoma. In The Native History of the Caddo: Their Place in Southeastern Archeology and Ethnohistory, edited by T. K. Perttula and J. E. Bruseth, pp. 47-68. Studies in Archeology 30. Texas Archeological Research Laboratory, The University of Texas at Austin. 
Bruseth, J. E. and T. K. Perttula

1981 Prehistoric Settlement Patterns at Lake Fork Reservoir. Texas Antiquities Permit Series No. 2. Archaeology Research Program, Southern Methodist University, Dallas, and Texas Antiquities Committee, Austin.

2006 Archeological Investigations at the Hudnall-Pirtle Site (41RK4): An Early Caddo Mound Center in Northeast Texas. Caddo Archeology Journal 15:57-158.

Bureau of Economic Geology

1965 Geologic Atlas of Texas, Tyler Sheet. Bureau of Economic Geology, The University of Texas at Austin.

1992 Geology of Texas Map. Bureau of Economic Geology, The University of Texas at Austin.

Burnett, B. A.

1990 The Bioarcheological Synthesis of the Gulf Coastal Plain Study Area Part I: The Bioarcheological Synthesis of the Eastern Portion of the Gulf Coastal Plain. In The Archeology and Bioarcheology of the Gulf Coastal Plain, by D. A. Story, J. A. Guy, B. A. Burnett, M. D. Freeman, J. C. Rose, D. G. Steele, B. W. Olive, and K. J. Reinhard, pp. 385-4 18. 2 Vols. Research Series No. 38. Arkansas Archeological Survey, Fayetteville.

Carlisle, J. D.

2001 "Choctaw Indians," Handbook of Texas Online (http://www.tshaonline.org/handbook/online/ articles/CCbmc57), accessed online, April 22, 2010. Published by the Texas State Historical Association.

Carlson, S. and J. Corbin

1999 Mission Dolores Revisited. Bulletin of the Texas Archeological Society 70:49-57.

Chipman, D. E.

1992 Spanish Texas, 1519-1821. University of Texas Press, Austin.

Clark, J.W. and J. E. Ivey

1974 Archaeological and Historical Investigations at Martin Lake, Rusk and Panola Counties, Texas. Research Report 32. Texas Archeological Survey, The University of Texas at Austin.

Cliff, M. B.

1997 The Middle Caddoan Period in the Lower Sulphur River Area. Journal of Northeast Texas Archaeology 9:9-16.

Cliff, M. B. and T. K. Perttula

2002 Results of National Register Investigations Conducted on 41PN175, Panola County, Texas. Archeological Studies Program, Report No. 32. Texas Department of Transportation, Austin.

Cliff, M. B. and E. C. Sills

2004 A Cherokee Trading House? Data Recovery at Site 41RK305, Rusk County, Texas. Current Archaeology in Texas 6(2):1-8. 
Texas. PBS\&J, Austin.

Cliff, M. B., M. M. Green, S. M. Hunt, D. Shanabrook, and D. E. Peter

1996 Excavations at 41CS151, Area C,White Oak Creek Mitigation Area (WOCMA), Cass County, Texas. White Oak Creek Mitigation Area Archeological Technical Series, Report of Investigations, No. 4. GeoMarine, Inc., Plano.

Cole, N. M.

1975 Early Historic Caddoan Mortuary Practices in the Upper Neches Drainage, East Texas. Master's thesis, Department of Anthropology, The University of Texas at Austin.

Corbin, J. E.

1998 Reflections on the Early Ceramic Period and the Terminal Archaic in South Central East Texas. Journal of Northeast Texas Archaeology 1 1:108-1 16.

Corbin, J. E. and J. P. Hart

1998 The Washington Square Mound Site: A Middle Caddo Mound Complex in South Central East Texas. Bulletin of the Texas Archeological Society 69:47-78.

Crawford, C. A. and L. C. Nordt

2001 Geoarchaeology. In Camp Maxey III:Archaeological Testing of 23 Prehistoric Sites, Lamar County, Texas, by R. B. Mahoney, pp. 12-18. Archaeological Survey Report No. 314. Center for Archaeological Research, The University of Texas at San Antonio.

Creel, D. G.

1996 Hatchel-Mitchell Site. In The New Handbook of Texas, Vol. 3, edited by R. Tyler, pp. 504-505. Texas State Historical Association, Austin.

Creel, D., D. Hudler, S. Wilson, C. Schultz, and C. Walker

2005 A Magnetometer Survey of Caddoan Mounds State Historic Site. Technical Report 51. Texas Archeological Research Laboratory, The University of Texas at Austin.

Davis, M.W., with A. C. Earls, C. R. Banks, and M. S. F. Tomka

19941987 Archeological Excavations at J. M. Robertson House Site (41RK67), Martin Creek Lake State Park, Rusk County, Texas. Texas Parks and Wildlife Department, Public Lands Division, Cultural Resources Program, Austin.

De Cunzo, L. A.

2005 Making a Living in Rural America: The Archaeology of Work. In Unlocking the Past: Celebrating Historical Archaeology in North America, edited by L. A. De Cunzo and J. H. Jameson, Jr., pp. 117-1 18. University Press of Florida, Gainesville.

Derrick, S. M. and D. E. Wilson

2001 The Effects of Epidemic Disease on Caddo Demographic Structure. Bulletin of the Texas Archeological Society 72:91-103. 
Diggs Jr., G. M., B. L. Lipscomb, M. D. Reed, and R. J. O'Kennon

2006 Illustrated Flora of East Texas, Volume One: Introduction, Pteridophytes, Gymnosperms, and Monocotyledons. Sida, Botanical Miscellany, No. 26. Botanical Research Institute of Texas, Fort Worth.

Dockall, J. E., R. C. Fields, S. L. Katauskas, A. E. Dase, and K. W. Kibler

2009 Archeological and Historic Resources Surveys of 6,925 Acres in the East Part of the Sabine Mine's South Hallsville No. 1 Mine-Rusk Permit, Panola and Rusk Counties, Texas. Report of Investigations No. 158. Prewitt and Associates, Inc., Austin.

Dickinson, S. D.

1941 Certain vessels from the Clements Place, an historic Caddo site. Bulletin of the Texas Archeological and Paleontological Society 13:117-132.

Duffield, L. F.

1963 The Wolfshead Site: An Archaic-Neo-American Site in San Augustine County, Texas. Bulletin of the Texas Archeological Society 34:83-141.

Duffield, L. F. and E. B. Jelks

1961 The Pearson site: A Historic Indian site in Iron Bridge Reservoir, Rains County, Texas. Archaeology Series No. 4. Department of Anthropology, The University of Texas at Austin.

Early, A. M. (editor)

1993 Caddoan Saltmakers in the Ouachita Valley: The Hardman Site. Research Series No. 43. Arkansas Archeological Survey, Fayetteville.

Ewers, J. C.

1973 The Influence of Epidemics on the Indian Populations and Cultures of Texas. Plains Anthropologist 18:104-115.

Farmer, G. R.

1951 Realm of Rusk County. Henderson.

Faulk, O.B.

1965 A Successful Failure. Steck-Vaughn Company, Austin.

Ferring, C. R.

1994 McGee Creek in Regional Paleoenvironmental Context. In Past Environments and Prehistory at McGee Creek Reservoir, Atoka County, Oklahoma, edited by C. R. Ferring, pp. 29-43. McGee Creek Archaeological Project Reports, Volume V, Part 4. Institute of Applied Sciences, University of North Texas, Denton.

1995 Middle Holocene Environments, Geology, and Archaeology in the Southern Plains. In Archaeological Geology of the Archaic Period in North America, edited by E. A. Bettis III, pp. 29-43. Special Paper 297. Geological Society of America, Boulder. 
Fields, R. C.

1979 Report on the 1977 University of Texas Field School Archeological Survey in Houston County, Texas. Department of Anthropology, The University of Texas at Austin.

Fields, R. C. and S. A. Tomka

1993 Hunter-Gatherer Mobility in Northeast Texas, 10,000-200 B.C. In Archeology in the Eastern Planning Region, Texas: A Planning Document, edited by N. A. Kenmotsu and T. K. Perttula, pp. 69-95. Cultural Resource Management Report 3. Texas Historical Commission, Department of Antiquities Protection, Austin.

Fields, R. C., M. E. Blake, and K.W. Kibler

1997 Synthesis of the Prehistoric and Historic Archeology of Cooper Lake, Delta and Hopkins Counties, Texas. Reports of Investigations No. 104. Prewitt and Associates, Inc., Austin.

Flores, D. L. (editor)

1984 Jefferson and Southwestern Exploration-The Freeman and Custis Accounts of the Red River Expedition of 1806. University of Oklahoma Press, Norman.

Foster, W. C. (editor)

1998 The La Salle Expedition to Texas: The Journal of Henri Joutel 1684-1687. Texas State Historical Association, Austin.

Fritz, G. J.

1994 The Value of Archaeological Plant Remains for Paleodietary Reconstruction. In Paleonutrition: The Diet and Health of Prehistoric Americans, edited by K. D. Sobolik, pp. 21-33. Occasional Paper No. 22. Center for Archaeological Investigations, Southern Illinois University at Carbondale.

Gadus, E. F. and M. A. Howard

1989 Archeological Background. In Archeological Survey and Testing Along Boone Creek, Louisiana Army Ammunition Plant, Webster Parish, Louisiana, edited the R. C. Fields, pp. 17-34. Reports of Investigations No. 64. Prewitt \& Associates, Inc., Austin.

Gadus, E. F., J. K. McWilliams, and R. C. Fields

2002 Data Recovery Excavations at the McGuire's Garden Site (41FT425), Jewett Mine, Freestone County, Texas. Reports of Investigations No. 134. Prewitt and Associates, Inc., Austin.

Gadus, E. F., R. C. Fields, C. B. Bousman, S. A. Tomka, and M. A. Howard

1992 Excavations at the Finley Fan Site (41HP159), Cooper Lake Project, Hopkins County, Texas. Reports of Investigations No. 78. Prewitt and Associates, Inc., Austin.

Galan, V., R. Rogers, T. K. Perttula, and E. Skokan Switek

1997 National Register Testing of Seven Sites in the Monticello B-2 Surface Mine, Titus County, Texas. Document No. 971085. Espey, Huston \& Associates, Inc., Austin. 
Gilmore, K.

1983 Caddoan Interaction in the Neches Valley, Texas. Reprints in Anthropology, No. 27. J\&L Reprint Company, Lincoln, Nebraska.

1986 French-Indian Interaction at an early eighteenth-century post: The Roseborough Lake Site, Bowie County, Texas. Contributions in Archaeology No. 5. Institute of Applied Sciences, North Texas State University, Denton.

Girard, J. S.

1994 Investigations at the James Pace Site (16DS268), De Soto Parish, Louisiana. Caddoan Archeology Newsletter $\mathrm{V}(1): 8-16$.

1997 Caddoan Settlement in the Red River Floodplain: Perspectives from the Willow Chute Bayou Area, Bossier Parish, Louisiana. Louisiana Archaeology 22:143-162.

2000 Regional Archaeology Program, Management Unit 1, Eleventh Annual Report. Northwestern State University, Natchitoches.

Goldschmidt, W. R.

1935 A Report on the Archeology of Titus County in East Texas. Bulletin of the Texas Archeological and Paleontological Society 7:89-99.

Goode, G. T., S. Hays, P. Maslyk, C. G. Ward, and J. Gonzalez

1997 Significance Testing at Prehistoric Archeological Site 41RK1 95, Rusk County, Texas. Texas Department of Transportation, Austin.

Granberry, D. S.

1995 William T. McKenzie Mound. The Record 46(1):1-18. Dallas Archeological Society, Dallas.

Greer, G. H.

1981 American Stoneware: The Art and Craft of Utilitarian Pottery. Schiffer Publishing Ltd., Exton, Pennsylvania.

Griffith, K.

2000 Soil Survey of Rusk County, Texas. Natural Resources Conservation Center, United States Department of Agriculture in cooperation with the Texas Agricultural Experiment Station and Texas State Soil and Water Conservation Board, Washington, D.C.

Groover, M. D.

2008 The Archaeology of North American Farmsteads. University Press of Florida, Gainesville.

Guy, J. A.

1990 Previous Archeological Investigations. In The Archeology and Bioarcheology of the Gulf Coastal Plain, by D. A. Story, J. A. Guy, B. A. Burnett, M. D. Freeman, J. C. Rose, D. G. Steele, B. W. Olive, and K. J. Reinhard, pp. 27-130.2 Vols. Research Series No. 38. Arkansas Archeological Survey, Fayetteville. 
Hamilton, D. L.

1997 Observations on Caddoan Burial Practices at the Sanders Site (4lLR2). Bulletin of the Texas Archeological Society 68:115-134.

Harris, R. K. I. M. Harris, and M. P. Miroir

1980 The Atlanta State Park site in Northeastern Texas. Louisiana Archaeology 6:233-239.

Hook, J. B.

1997 The Alabama-Coushatta Indians. Texas A\&M University Press, College Station.

Hudson, C. M.

1997 Knights of Spain, Warriors of the Sun: Hernando de Soto and the South's Ancient Chiefdoms. University of Georgia Press, Athens.

Hunter, R. R. Jr. and G. L. Miller

1994 English Shell-edged Earthenware. Antiques CXLV (No. 3):432-443.

2009 Suitable for Framing: Decorated Shell-Edge Earthenware. Early American Life (August):8-19.

Jackson, A. T.

1933 Some Pipes of East Texas. Bulletin of the Texas Archeological and Paleontological Society 5:69-86.

1934 Types of East Texas Pottery. Bulletin of the Texas Archeological and Paleontological Society 6:38-57.

1936 A Perpetual Fire Site. Bulletin of the Texas Archeological and Paleontological Society 8:134-174.

Jackson, J. M.

1982 A Cultural Resource Survey in Martin Lake Area D: First Five-Year Area. Research Report No. 85. Texas Archeological Survey, The University of Texas at Austin.

Jelks, E. B.

1961 Excavations at Texarkana Reservoir, Sulphur River, Northeastern Texas. River Basin Survey Papers No. 21. Bulletin No. 179. Bureau of American Ethnology, Smithsonian Institution, Washington, D.C.

1965 The Archeology of McGee Bend Reservoir. Ph.D. dissertation, Department of Anthropology, The University of Texas at Austin.

Jelks, E. B. (editor)

1967 The Gilbert Site: A Norteno Focus Site in Northeastern Texas. Bulletin of the Texas Archeological Society 37:1-248.

Jensen, H. P.

1968 Archaeological Investigations in the Toledo Bend Reservoir, 1966-1967. Archaeology Salvage Project, Southern Methodist University, Dallas.

Jeter, M. D., J. C. Rose, G. I. Williams, Jr., and A. M. Harmon

1989 Archeology and Bioarcheology of the Lower Mississippi Valley and Trans-Mississippi South in Arkansas and Louisiana. Research Series No. 37. Arkansas Archeological Survey, Fayetteville. 
Johnson, L., Jr.

1961 An Archeological Survey of Blackburn Crossing Reservoir on the Upper Neches River. Bulletin of the Texas Archeological Society 31:213-238.

1962 The Yarbrough and Miller Sites of Northeastern Texas, with a Preliminary Definition of the La Harpe Aspect. Bulletin of the Texas Archeological Society 32:141-284.

1989 Great Plains Interlopers in the Eastern Woodlands in Late Paleoindian Times: The Evidence from Oklahoma, Texas, and Areas Close By. Report Series No. 36. Office of the State Archeologist, Texas Historical Commission, Austin.

Jones, B. C.

1968 The Kinsloe Focus: A study of seven historic Caddoan sites in Northeast Texas. Master's thesis, Department of Anthropology, University of Oklahoma, Norman.

Jordan, T. G.

1978 Texas Log Buildings: A Folk Architecture. University of Texas Press, Austin.

1981 Trails to Texas: Southern Routes of Western Cattle Ranching. University of Nebraska Press, Lincoln.

Kelley, D. B. (editor)

1997 Two Caddoan Farmsteads in the Red River Valley: The Archeology of the McLelland and Joe Clark Sites. Research Series No. 51. Arkansas Archeological Survey, Fayetteville.

Kelley, D. B. and C. L. Coxe

1998 Cultural Resources Survey of Levee Rehabilitation/Restoration Areas along the Red River between Fulton, Arkansas and the Louisiana State Line: Items 4, 5, and 9. Coastal Environments, Inc., Baton Rouge.

Kenmotsu, N. A.

1992 The Mayhew Site: A Possible Hasinai Farmstead, Nacogdoches County, Texas. Bulletin of the Texas Archeological Society 63:135-173.

Kenmotsu, N. A., J. E. Bruseth, and J. E. Corbin

1993 Moscoso and the Route in Texas: A Reconstruction. In The Expedition of Hernando de Soto West of the Mississippi, 1541-1543, edited by G. A. Young and M. P. Hoffman, pp. 106-131. University of Arkansas Press, Fayetteville.

Kleinschmidt, U. K.W.

1982 Review and Analysis of the A. C. Saunders Site, 41AN19, Anderson County, Texas. Master's thesis, Department of Anthropology, The University of Texas at Austin.

Kotter, S. M., R. Rogers, R. Taylor, K. Reese-Taylor, and W. P. Glander

1993 Archeological Investigations within the Monticello B-2 First Five Year Disturbance Area, Titus County, Texas. Document No. 920013. Espey, Huston \& Associates, Inc., Austin. 
Lange, C. H.

1974 The Caddo Treaty of July 1, 1835. In Caddoan Indians II, pp. 159-321. Garland Publishing, Inc., New York.

Lebo, S. A.

1987 Local Utilitarian Stonewares: A Diminishing Artifact Category. In Historic Buildings, Material Culture, and People of the Prairie Margin: Architecture, Artifacts, and Synthesis of Historic Archaeology, edited by D. H. Jurney and R.W. Moir, pp. 121-142. Volume V. Archaeology Research Program, Institute for the Study of Earth and Man, Southern Methodist University, Dallas.

Lewis, G. A.

1987 The Clements Brothers' Farm Site 41CS25. Master's thesis, Department of Anthropology, The University of Texas at Austin.

Lipscomb, C. A.

2001a "Cherokee Indians," Handbook of Texas Online (http://www.tshaonline.org/handbook/online/ articles/CC/mbc51), accessed April 20, 2010. Published by the Texas State Historical Association.

2001c "Shawnee Indians," Handbook of Texas Online (http://www.tshaonline.org/handbook/online/ articles/SS/bms25), accessed April 2, 2010. Published by the Texas State Historical Association.

Lohse, J. C., with contributions by T. K. Perttula and R. A. Ricklis

2005 National Register Eligibility of the Weaver Creek Site, 41BW692, Bowie County, Texas. Archeological Studies Program, Report No. 69. Texas Department of Transportation, Environmental Affairs Division, Austin, and Coastal Environments, Inc., Baton Rouge and Corpus Christi.

Lohse, J. C. and C. B. Bousman

2006 National Register Evaluation of Eight Sites at Camp Swift Army National Guard Training Center, Bastrop County, Texas: Swift V. Archaeological Studies Report No. 8. Center for Archaeological Studies, Texas State University-San Marcos.

Majewski, T. and M. J. O’Brien

1987 The Use and Misuse of Nineteenth-Century English and American Ceramics in Archaeological Analysis. In Advances in Archaeological Method and Theory, Volume 11, edited by M. B. Schiffer, pp. 97-209. Academic Press, Inc., New York.

Martin, H. N.

2001 "Alabama-Coushatta Indians," Handbook of Texas Online (http://www.tshaonline.org/handbook/ online/articles/bmal 9.html), accessed April 20, 2010. Published by the Texas State Historical Association.

Martin, W. A., T. K. Perttula, N. A. Kenmotsu, L. Roark, J. Wise, J. E. Bruseth, J. Ippolito, V. Hubbard, and W. Kingsborough

1995 Cultural Resource Management Planning for the National Forest and Grasslands in Texas. Cultural Resource Management Report 6. Department of Antiquities Protection, Texas Historical Commission, Austin. 
McClurkan, B. B., W. T. Field, and J. N. Woodall

1966 Excavations in Toledo Bend Reservoir, 1964-65. Papers of the Texas Archeological Salvage Project, No. 8. Texas Archeological Salvage Project, The University of Texas at Austin.

McDonald, A. J.

1972 An Archeological Survey of the Martin Lake Area, Rusk and Panola Counties, Texas. Research Report No. 14. Texas Archeological Salvage Project, The University of Texas at Austin.

McGregor, D. E.

1997 Archaeological Investigations at 41HP137. In Archaeological Survey of Cooper Lake, Delivery Order Numbers 2, 3 \& 4, 1987: Cultural Resource Studies for Cooper Lake, Hopkins and Delta Counties, Texas, by D. E. McGregor, M. M. Green, D. H. Jurney, W. A. Martin, R. W. Moir, and J. W. Saunders, pp. 34 1-361. 2 Vols. Archaeology Research Program, Southern Methodist University, Dallas.

McKee, J. O.

1989 The Choctaw. Chelsea House Publishers, New York.

McNatt, L., M. D. Freeman, P. Schuchert, M. Howard, S. A. Tomka, C. G. Ward, and C. Beceiro

2001 Archeological Survey and History of Colorado Bend State Park, San Saba and Lampasas Counties, Texas. Texas Parks and Wildlife Department, Cultural Resources Program, Austin.

Meissner, B. A.

1997 Making the Man: Remains of Clothing Recovered from the Alamodome Project. In Archaeology at the Alamodome: Investigations of a San Antonio Neighborhood in Transition, Volume III: Artifacts and Special Studies, edited by A. A. Fox, M. Renner, and R. J. Hard, pp. 119-164. Archaeological Survey Report No. 238. Center for Archaeological Research, The University of Texas at San Antonio.

Middlebrook, T.

1994 An Update of Archaeological Investigations at the Tyson Site (41SY92). Journal of Northeast Texas Archaeology 3:1-36.

1997 The Caddoan Occupation of the Attoyac and Angelina River Basins in the Middle Caddoan Period. Journal of Northeast Texas Archaeology 10:36-40.

Middlebrook, T. and T. K. Perttula

1997 The Middle Caddoan Period in East Texas: A Summary of the Findings of the East Texas Caddoan Research Group. Journal of Northeast Texas Archaeology 9:1-8.

Miroir, M. P., R. K. Harris, J. C. Blaine, and J. McVay

1973 Benard de la Harpe and the Nassonite post. Bulletin of the Texas Archeological Society 44:1 13-168.

Moir, R.W.

1987 Socioeconomic and Chronometric patterning of Window Glass. In Historic Buildings, Material Culture, and People of the Prairie Margin: Architecture, Artifacts, and Synthesis of Historic Archaeology, edited by D. H. Jurney and R.W. Moir, pp. 73-81.Volume V. Archaeology Research Program, Institute for the Study of Earth and Man, Southern Methodist University, Dallas. 
1988 Windows and Window Glass. In Historic Farming on the Hogwallow Prairies: Ethnoarchaeological Investigations of the Mountain Creek Area, North Central Texas, Volume II, compiled by D. H. Jurney, S. A. Lebo, and M. M. Gren, pp. 263-272. Archaeology Research Program, Institute for the Study of Earth and Man, Southern Methodist University, Dallas.

Moncure, H. B.

1984 Historical Archaeology at the Walling Cabin, 41RK104, Rusk County, Texas. Texas Archeological Survey Research Report 88. The University of Texas at Austin.

Moore, C. B.

1912 Some Aboriginal Sites on Red River. Journal of the Academy of Natural Sciences of Philadelphia, Volume 14, part 4.

Morfi, Fr. J. A. de

1935 History of Texas, 1663-1779. Publications No. 6, edited by C. E. Castaneda. Quivira Society, Santa Fe.

Neuman, R.W.

1974 Historical Locations of Certain Caddoan Tribes. In Caddoan Indians II, pp. 9-158. Garland Publishing, Inc., New York.

Newell, H. P. and A. D. Krieger

1949 The George C. Davis Site, Cherokee County, Texas. Memoirs No. 5. Published jointly by the Society for American Archaeology and the University of Texas, Menasha, Wisconsin.

Newman. T. S.

1970 A Dating Key for Post-Eighteenth Century Bottles. Historical Archaeology 4(1):70-75.

Nunley, M. C.

2001 "Kickapoo," Handbook of Texas Online (http://www.tshaonline.org/handbook/online/articles/KK/ bmk9), accessed April 20, 2010. Published by the Texas State Historical Association.

Pearce, J. E.

1932 The Archaeology of East Texas. American Anthropologist 34:670-687.

Perdue, T.

1989 The Cherokee. Chelsea House Publishers, New York.

Perttula, T. K.

1984 Patterns of Prehistoric Lithic Raw Material Utilization in the Caddoan Area: The Western Gulf Coastal Plain. In Prehistoric Chert Exploitation - Studies from the Midcontinent, edited by B. M. Butler and E. E. May, pp. 129-148. Occasional Paper No. 2. Center for Archaeological Investigations, Southern Illinois University at Carbondale.

1989 The Paleoindian Archaeological Record in Northeast Texas: Evidence from Avocational Collecting Activities. Current Research in the Pleistocene 6:19-21.

1992 “The Caddo Nation”: Archaeological and Ethnohistoric Perspectives. University of Texas Press, Austin. 
1993 The Development of Agriculture in Northeast Texas before A.D. 1600. In Archeology in the Eastern Planning Region, Texas: A Planning Document, edited by N. A. Kenmotsu and T. K. Perttula, pp.

121-146. Cultural Resource Management Report 3. Texas Historical Commission, Department of Antiquities Protection, Austin.

1996 Caddoan Area Archaeology Since 1990. Journal of Archaeological Research 4(4):295-348.

1998 A Compendium of Radiocarbon and Oxidizable Carbon Ratio Dates from Archaeological Sites in East Texas, with a Discussion of the Age and Dating of Select Components and Phases. Radiocarbon 39(3):305-341.

2004 The Prehistoric and Caddoan Archeology of the Northeastern Texas Pineywoods. In The Prehistory of Texas, edited by T. K. Perttula, pp. 370-407. Texas A\&M University Press, College Station.

2007 Kinsloe Focus Artifact Assemblages and Nadaco Caddo. Journal of Northeast Texas Archaeology 26:116-119.

Perttula, T. K. (editor)

1999 The Hurricane Hill Site (41HP106): The Archaeology of a Late Archaic/Early Ceramic and Early-Middle Caddoan Settlement in Northeast Texas. 2 Vols. Special Publication No. 4. Friends of Northeast Texas Archaeology, Pittsburg and Austin.

Perttula, T. K. and J. E. Bruseth

1983 Early Caddoan Subsistence Strategies, Sabine River Basin, East Texas. Plains Anthropologist 28(99):9-21.

1995 Trade and Exchange in Eastern Texas, 1100 B.C.-A.D. 800. Louisiana Archaeology 17:93-121.

Perttula, T. K. and B. Nelson

2006 Test Excavations at Three Caddo Sites at Mission Tejas State Park, Houston County, Texas. Report of Investigations No. 76. Archeological \& Environmental Consultants, LLC, Austin.

2007 Archeological Survey Investigations and Test Excavations at 41CE354 at the North and South Lake areas of the H.R.C. Cherokee Tree Farm, L. P. Project, Cherokee County, Texas. Report of Investigations No. 80. Archeological \& Environmental Consultants, LLC, Austin.

Perttula, T. K. and R. Rogers

2007 The Evolution of a Caddo Community in Northeastern Texas: The Oak Hill Village Site (41RK214), Rusk County, Texas. American Antiquity 72(1):71-94.

Perttula, T. K., R. C. Fields, J. E. Corbin, and N. A. Kenmotsu

1993 The Emergence of Sedentism in the Northeast Texas Archeological Region, ca. 500 B.C. to A.D. 1000. In Archeology in the Eastern Planning Region, Texas: A Planning Document, edited by N. A. Kenmotsu and T. K. Perttula, pp. 97-120. Cultural Resource Management Report 3. Texas Historical Commission, Department of Antiquities Protection, Austin. 
Perttula, T. K., M. Tate, H. Neff, J.W. Cogswell, M. D. Glascock, E. Skokan, S. Mulholland, R. Rogers, and B. Nelson

1998 Analysis of the Titus Phase Mortuary Assemblage at the Mockingbird Site ("Kahbakayammaahin"), 41TT550. Document No. 970849. PBS\&J, Austin.

Perttula, T. K., J. E. Bruseth, N. A. Kenmotsu, D. J. Prikryl, W. A. Martin, L. Banks, J. Smith, N. G. Reese, and S. A. Iruegas

2001 Archeological Investigations on the Red River and Tributaries: Summary of the Findings of the 1991 and 1992 Texas Archeological Society Field School in Red River and Lamar Counties, Texas. Bulletin of the Texas Archeological Society 72:250.

Ralph, R.

1984 “41RK133," TexSite Site Survey Form. Texas Historical Commission Texas Archeological Sites Atlas (http://nueces.thc.state.tx.us), accessed April 20, 2010.

Richardson, R. N.

1958 Texas, the Lone Star State. Prentice-Hall, Inc., Englewood Cliffs, New Jersey.

Richardson, T. C.

1940 East Texas, Its History and Its Makers. Lewis Historical Publishing Co., New York.

Ricklis, R. A.

2004 The Archeology of the Native American Occupation of Southeast Texas. In The Prehistory of Texas, edited by T. K. Perttula, pp. 181-202. Texas A\&M University Press, College Station.

Ricklis, R. A. (compiler and editor)

Archaeological Testing at 41 UR77 on Big Sandy Creek, Upshur County, Texas: An Interim Report. Review draft. Coastal Environments, Inc., Baton Rouge and Corpus Christi.

Rogers, J. D. and G. M. Sabo III

2004 Caddo. In Southeast, Volume 14, Handbook of the North American Indians, edited by R. D. Fogelson, pp. 616-631. Smithsonian Institution, Washington, D.C.

Rogers, R. and T. K. Perttula

2004 The Oak Hill Village (41RK2 14), Rusk County, Texas. Document No. 030083. PBS\&J, Austin.

Rogers, R., M. A. Nash, and T. K. Perttula

2001 Excavations at the Herman Bellew Site (41RK222), Rusk County, Texas. Document No. 000021. PBS\&J, Austin.

Rogers, R., M. B. Cliff, T. K. Perttula, G. Rutenberg, S. Victor, P. Dering, and M. Malainey

2003 Excavations at the Alex Justiss Site, 41TT13, Titus County, Texas. Archeological Studies Program Report No. 36. Texas Department of Transportation, Austin. 
Rose, J. C., M. P. Hoffman, B. A. Burnett, A. M. Harmon, and J. E. Barnes

1998 Skeletal Biology of the Prehistoric Caddo. In The Native History of the Caddo: Their Place in Southeastern Archeology and Ethnohistory, edited by T. K. Perttula and J. E. Bruseth, pp. 123-136. Studies in Archeology 30. Texas Archeological Research Laboratory, The University of Texas at Austin.

Rose, J. C., D. G. Steele, B. A. Burnett, K. J. Reinhard, and B. W. Olive

1999 Gulf Coastal Plain. In Bioarcheology of the South Central United States, edited by J. C. Rose, pp. 83132. Research Series No. 55. Arkansas Archeological Survey, Fayetteville.

Saunders, J.W. and T. Allen

1997 The Archaic Period. Louisiana Archaeology 22:1-30.

Saunders, J. W., R. D. Mandel, R. T. Saucier, E. T. Allen, C. T. Hallmark, J. K. Johnson, E. H. Jackson, C. M. Allen, G. L. Stringer, D. S. Frink, J. K. Feathers, S. Williams, K. J. Gremillion, M. F. Vidrine, and R. Jones

1997 A Mound Complex in Louisiana at 5400-5000 Years before the Present. Science 277:1796-1799.

Schambach, F. F.

1982 An Outline of Fourche Maline Culture in Southwest Arkansas. In Arkansas Archeology in Review, edited by N. L. Trubowitz and M. D. Jeter, pp. 132-197. Research Series No. 15. Arkansas Archeological Survey, Fayetteville.

1983 The Archeology of the Great Bend Region in Arkansas. In Contributions to the Archeology of the Great Bend Region of the Red River Valley, Southwest Arkansas, edited by F. F. Schambach and F. Rackerby, pp. 1-11. Research Series No. 22. Arkansas Archeological Survey, Fayetteville.

1989 The End of the Trail: The Route of Hernando De Soto's Army Through Southwest Arkansas and East Texas. The Arkansas Archeologist 27/28:9-33.

1996 Mounds, Embankments, and Ceremonialism in the Trans-Mississippi South. In Mounds, Embankments, and Ceremonialism in the Midsouth, edited by R. C. Mainfort and R. Walling, pp. 36-43. Research Series No. 46. Arkansas Archeological Survey, Fayetteville.

1997 The Development of the Burial Mound Tradition in the Caddo Area. Journal of Northeast Texas Archaeology 9:53-72.

1998 Pre-Caddoan Culture in the Trans-Mississippi South: A Beginning Sequence. Research Series No. 53. Arkansas Archeological Survey, Fayetteville.

2001 Fourche Maline and Its Neighbors: Observations on an Important Woodland Period Culture of the Trans-Mississippi South. The Arkansas Archeologist 40:21-50.

2002 Fourche Maline: A Woodland Period Culture of the Trans-Mississippi South. In The Woodland Southeast, edited by D. G. Anderson and R. C. Mainfort, Jr., pp. 91-1 12. University of Alabama Press, Tuscaloosa.

Scott, S. L. and H. E. Jackson

1998 Early Caddo Ritual and Patterns of Animal Use: An Analysis of Faunal Remains from the Crenshaw Site (3MI6), Southwestern Arkansas. The Arkansas Archeologist 37:1-37. 
Shafer, H. J.

1981 Archeological Investigations at the Attaway Site, Henderson County, Texas. Bulletin of the Texas Archeological Society 52:147-178.

Sherman, D. L.

2001 NRHP Eligibility Testing (41RK107, 41RK240, 41RK242, 41RK243, 41RK276, and 41RK2186, and Additional Testing (41RK243) Investigations within the Oak Hill DIII Mine Permit No. 46, Rusk County, Texas. PBS\&J, Austin.

Slaughter, B. H. and B. R. Hoover

1965 An Antler Artifact from the Late Pleistocene of Northeastern Texas. American Antiquity 30:351-352.

Smith, F. T.

1995 The Caddo Indians: Tribes as the Emergence of Empires, 1542-1854. Texas A\&M University Press, College Station.

Society for Historical Archaeology

2010 "Historic Glass Bottle Identification \& Information Website," (http://www.sha.org/bottle/index), accessed online, July 2, 2010.

Stahle, D.W.

1996 The Hydroclimatic Application of Tree-Ring Chronologies. In Tree Rings, Environment and Humanity: Proceedings of the International Conference, Tucson, Arizona, 17-2 1 May 1994, edited by J. S. Dean, D. M. Meko, and T. W. Sweetman, pp. 119-126. Radiocarbon, Department of Geosciences, The University of Arizona, Tucson.

Stahle, D. W. and M. K. Cleaveland

1988 Texas Drought History Reconstructed and Analyzed from 1698 to 1980. Journal of Climate 1:59-74.

1992 Reconstruction and Analysis of Spring Rainfall over the Southeastern U.S. for the Past 1000 Years. Bulletin of the American Meteorological Society 73:1947-1961.

1993 Southern Oscillation Extreme Reconstructed from Tree Rings of the Sierra Madre Occidental and southern Great Plains. Journal of Climate 6:129-140.

1994 Tree-Ring Reconstructed Rainfall over the Southeastern U.S.A. during the Medieval Warm period and Little Ice Age. Climatic Change 26:194-212.

1995 Texas Paleoclimatic Data from Daily and Millenial Time Scales. In The Changing Climate of Texas: Predictability and Implications for the Future, edited by J. Norwine, J. R. Giardino, G. R. North, and J. B. Valdes, pp. 49-69. GeoBooks, College of Geosciences and Maritime Studies, Texas A\&M University, College Station.

Stahle, D. W., M. K. Cleaveland, and J. G. Hehr

1985 A 450-Year Drought Reconstruction for Arkansas, United States. Nature 316:530-532. 
Story, D. A.

1990 Cultural History of the Native Americans. In The Archeology and Bioarcheology of the Gulf Coastal Plain, by D. A. Story, J. A. Guy, B. A. Burnett, M. D. Freeman, J. C. Rose, D. G. Steele, B. W. Olive, and K. J. Reinhard, pp. 163-366. 2 Vols. Research Series No. 38. Arkansas Archeological Survey, Fayetteville.

1997 1968-1970 Archeological Investigations at the George C. Davis Site, Cherokee County, Texas. Bulletin of the Texas Archeological Society 68:1-113.

1998 The George C. Davis Site: Glimpses into Early Caddoan Symbolism and Ideology. In The Native History of the Caddo: Their Place in Southeastern Archeology and Ethnohistory, edited by T. K. Perttula and J. E. Bruseth, pp. 9-43. Studies in Archeology 30. Texas Archeological Research Laboratory, The University of Texas at Austin.

2000 Introduction. In The George C. Davis Site, Cherokee County, Texas, by H. P. Newell and A. D. Krieger, pp. 1-31. Second edition. Society for American Archaeology, Washington, D.C.

Story, D. A. (editor)

1981 Archeological Investigations at the George C. Davis Site, Cherokee County, Texas: Summers of 1979 and 1980. Occasional Papers No. 1. Texas Archeological Research Laboratory, The University of Texas at Austin.

1982 The Deshazo Site, Nacogdoches County, Texas, Vol. 1. Texas Antiquities Permit Series No. 7. Texas Antiquities Committee, Austin.

1995 The Deshazo Site, Nacogdoches County, Texas, Volume 2: Artifacts of Native Manufacture. Studies in Archeology 21. Texas Archeological Research Laboratory, The University of Texas at Austin.

Story, D. A. and D. G. Creel

1982 The Cultural Setting. In The Deshazo Site, Nacogdoches County, Texas, Vol. 1, edited by D. A. Story, pp. 20-34. Texas Antiquities Permit Series No. 7. Texas Antiquities Committee, Austin.

Suhm, D. A. and E. B. Jelks (editors)

1962 Handbook of Texas Archeology: Type Descriptions. Texas Archeological Society Special Publication 1 and Texas Memorial Museum Bulletin 4, The University of Texas at Austin.

Swanton, J. R.

1942 Source Material on the History and Ethnology of the Caddo Indians. Bulletin 132. Smithsonian Institution, Bureau of American Ethnology, Washington, D.C.

1946 The Indians of the Southeastern United States. Bulletin 137. Bureau of American Ethnology, Smithsonian Institution, Washington, D.C.

Texas Historical Commission

n.d. Historical Marker, "United Methodist Church of Henderson." Texas Archeological Sites Atlas (http:// nueces.thc.state.tx.us), accessed online, April 20, 2010.

2010 Texas Archeological Sites Atlas, Historical Designations, Rusk County, (http://nueces.thc.state.tx.us), accessed online, July 5, 2010. 
Thurmond, J. P.

1990 Archeology of the Cypress Creek Basin, Northeastern Texas and Northwestern Louisiana. Studies in Archeology 5. Texas Archeological Research Laboratory, The University of Texas at Austin.

Turner, E. S. and T. R. Hester

1999 A Field Guide to Stone Artifacts of Texas Indians. Gulf Publishing, an imprint of Rowman \& Littlefield Publishers, Inc., Lanham, Maryland.

Turner, R. L. and J. E. Smith, with contributions by T. K. Perttula, B. Nelson, M. Walters, and B. Gonzalez 2003 The Harold Williams Site (41CP10) and the Texas Archeological Society Field School of 1967. Bulletin of the Texas Archeological Society 73:1-68.

Walters, M. and P. Haskins

2000 The Bryan Hardy Site (41SM55), Smith County, Texas. Journal of Northeast Texas Archaeology 12:1-26.

Walters, M., P. Haskins, D. H. Jurney, S. E. Goldborer, and T. K. Perttula

1998 Archaeological Investigations at the Redwine Site (41SM193), Smith County, Texas. Journal of Northeast Texas Archaeology 11:1-38.

Waters, M. R. and T. W. Stafford, Jr.

2007 Redefining the Age of Clovis: Implications for the Peopling of the Americas. Science 315:1122-1 126.

Webb, C. H.

1984 The Bellevue Focus: A Marksville-Troyville Manifestation in Northwestern Louisiana. Louisiana Archaeology 9:251-274.

Webb, C. H. and R. R. McKinney

1975 Mounds Plantation (16CD12), Caddo Parish, Louisiana. Louisiana Archaeology 2:39-127.

Webb, C. H., F. E. Murphey, W. G. Ellis, and H. R. Green

1969 The Resch Site, 41HS16, Harrison County, Texas. Bulletin of the Texas Archeological Society 40:3-106.

Webb, C. H., J. L. Shiner, and E.W. Roberts

1971 The John Pearce Site (16CD56): A San Patrice Site in Caddo Parish, Louisiana. Bulletin of the Texas Archeological Society 42:1-49.

Wedel, M. M.

1978 La Harpe's 1719 Post on the Red River and Nearby Caddo Settlements. Bulletin No. 30. Texas Memorial Museum, Austin.

Weinstein, R. A., D. B. Kelley, and J.W. Saunders (editors)

2003 The Louisiana and Arkansas Expeditions of Clarence Bloomfield Moore. University of Alabama Press, Tuscaloosa. 
Wells, T.

2000 Nail Chronology: The Use of Technologically Derived Features. In Approaches to Material Culture Research for Historical Archaeologists, compiled by D. R. Brauner, pp. 318-339. $2^{\text {nd }}$ Edition. The Society for Historical Archaeology, California, Pennsylvania.

Whitten, D.

2010 "Glass Factory Marks on Bottles," (http://myinsulators.com/glass-factories/bottlemarks.html), accessed online, July $2,2010$.

Williams, S.

1974 The Aboriginal Location of the Kadohadocho and Related Tribes. In Caddoan Indians I, pp. 281-330. Garland Publishing, Inc., New York.

Winfrey, D. H.

1961 A History of Rusk County. Texian Press, Waco, Texas.

Woodall, J. N.

1969 Archaeological Excavations in the Toledo Bend Reservoir, 1966. Contributions in Anthropology No. 3. Department of Anthropology, Southern Methodist University, Dallas.

Wyckoff, D. G. and R. Bartlett

1995 Living on the Edge: Late Pleistocene-Early Holocene Cultural Interactions along the Southeastern Woodlands-Plains Border. In Native American Interactions: Multiscalar Analyses and Interpretations in the Eastern Woodlands, edited by M. S. Nassaney and K. E. Sassaman, pp. 27-72. University of Tennessee Press, Knoxville. 



\section{Appendix 1 \\ Previously Recorded Archeological Sites}

APPENDIX 1. REDACTED

Note: Park boundaries are incorrect in this image; please refer to Appendix 3 for correct Park configuration. 


\section{Appendix 2, Shovel Test Descriptions}

ST $1 \quad 0-10 \mathrm{~cm}$, dark grayish-brown sandy loam; 10-58 cm, yellowish-brown sandy loam with strong brown mottles; 58-61 cm+, red clay

ST $2 \quad$ 0-7 cm, dark grayish-brown sandy loam; 7-60 cm, yellowish-brown sandy loam; 60-62 cm+, red clay; prehistoric and historic artifacts in the dark grayish-brown and yellowish-brown sandy loam zones (41RK467)

ST 3 0-10 cm, dark grayish-brown sandy loam; 10-33 cm, dark yellowish-brown sandy loam; 33-60 cm, yellowish-brown sandy loam; 60-64 cm+, red clay

ST $4 \quad$ 0-5 cm, dark grayish-brown sandy loam; 5-68 cm, yellowish-brown sandy loam; 68-71 cm+, red clay

ST 5 0-5 cm, dark grayish-brown sandy loam; 5-52 cm, yellowish-brown sandy loam; 52-56 cm+, strong brown sandy clay

ST 6 0-10 cm, dark grayish-brown sandy loam; 10-60 cm, yellowish-brown sandy loam; 60-63 cm+, strong brown clay; historic artifacts in the dark grayish-brown and yellowish-brown sandy loam zones (4lRK467)

ST $7 \quad 0-5 \mathrm{~cm}$, dark grayish-brown sandy loam; 5-55 cm, yellowish-brown sandy loam; 55-58 cm+, strong brown sandy clay

ST 8 0-10 cm, dark grayish-brown sandy loam; 10-69 cm, yellowish-brown sandy loam; 69-71 cm+, red clay; historic artifacts in the dark grayish-brown and yellowish-brown sandy loam zones (41RK467)

ST 9 0-10 cm, dark grayish-brown sandy loam; 10-57 cm, yellowish-brown sandy loam with strong brown mottles; 57-61 cm+, red clay; historic artifacts in the dark grayish-brown and yellowishbrown sandy loam zones (41RK467)

ST 10 0-10 cm, dark grayish-brown sandy loam; 10-55 cm, yellowish-brown sandy loam with strong brown mottles; 55-59 cm+, red clay; historic artifacts in the yellowish-brown sandy loam zone (41RK467)

ST 11 0-5 cm, dark grayish-brown sandy loam; 5-94 cm, yellowish-brown sandy loam; 94-97 cm+, strong brown sandy clay

ST 12 0-10 cm, dark grayish-brown sandy loam; 10-100 cm+, yellowish-brown sandy loam; prehistoric artifacts in the yellowish-brown sandy loam zone (Site \#1, 41RK605)

ST 13 0-10 cm, dark grayish-brown sandy loam; 10-90 cm, yellowish-brown sandy loam; 90-93 cm+, strong brown sandy clay

ST 14 0-10 cm, dark grayish-brown sandy loam; 10-85 cm, yellowish-brown sandy loam; 85-88 cm+, strong brown sandy clay

ST 15 0-10 cm, dark grayish-brown sandy loam; 10-100 cm+, yellowish-brown sandy loam

ST 16 0-10 cm, dark grayish-brown sandy loam; 10-100 cm+, yellowish-brown sandy loam 
ST 17 0-15 cm, dark grayish-brown sandy loam; 15-100 cm+, yellowish-brown sandy loam

ST 18 0-40 cm, disturbed sediments; 40-60 cm, yellowish-brown sandy loam; 60-63 cm+, strong brown sandy clay

ST 19 0-5 cm, dark grayish-brown sandy loam; 5-56 cm, yellowish-brown sandy loam; 56-58 cm+, strong brown sandy clay

ST $20 \quad$ 0-75 cm, yellowish-brown sandy loam; 75-78 cm+, strong brown sandy clay

ST $21 \quad 0-5 \mathrm{~cm}$, dark grayish-brown sandy loam; 5-68 cm, yellowish-brown sandy loam; 68-70 cm+, red clay

ST 22 0-5 cm, dark grayish-brown sandy loam; 5-63 cm, yellowish-brown sandy loam; 63-66 cm+, strong brown clay

ST 23 0-5 cm, dark grayish-brown sandy loam; 5-80 cm, yellowish-brown sandy loam; 80-82 cm+, red clay

ST 24 0-5 cm, dark grayish-brown sandy loam; 5-65 cm, yellowish-brown sandy loam; 65-68 cm+, strong brown clay

ST 25 0-7 cm, dark grayish-brown sandy loam; 7-92 cm, yellowish-brown sandy loam; 92-94 cm+, strong brown sandy clay

ST 26 0-15 cm, dark grayish-brown sandy loam; 15-52 cm, yellowish-brown sandy loam; $52-56 \mathrm{~cm}+$, strong brown sandy clay

ST 27 0-7 cm, dark grayish-brown sandy loam; 7-60 cm, yellowish-brown sandy loam; 60-62 cm+, red clay

ST 28 0-10 cm, dark grayish-brown sandy loam; 10-45 cm, yellowish-brown sandy loam; 45-48 cm+, strong brown sandy clay

ST 29 0-14 cm, disturbed sediments; 14-50 cm, yellowish-brown sandy loam; 50-52 cm+, strong brown sandy clay

ST $30 \quad 0-5 \mathrm{~cm}$, dark grayish-brown sandy loam; 5-48 cm, yellowish-brown sandy loam; 48-50 cm+, strong brown sandy clay

ST $31 \quad 0-5 \mathrm{~cm}$, dark grayish-brown sandy loam; 5-50 cm, yellowish-brown sandy loam; 50-52 cm+, strong brown sandy clay

ST 32 0-10 cm, dark grayish-brown sandy loam; 10-55 cm, yellowish-brown sandy loam; 55-58 cm+, strong brown sandy clay

ST 33 0-5 cm, dark grayish-brown sandy loam; 5-67 cm, yellowish-brown sandy loam; 67-69 cm+, strong brown sandy clay

ST 34 0-10 cm, dark grayish-brown sandy loam; 10-93 cm, yellowish-brown sandy loam; 93-96 cm+, strong brown clay; prehistoric artifacts in the yellowish-brown sandy loam (Site \#1, 41RK605)

ST 35 0-6 cm, dark grayish-brown sandy loam; 6-57 cm, yellowish-brown sandy loam; 57-58 cm+, strong brown sandy clay 
ST 36 0-10 cm, dark grayish-brown sandy loam; 10-91 cm, yellowish-brown sandy loam; $91-95 \mathrm{~cm}+$, strong brown sandy clay

ST 37 0-5 cm, dark grayish-brown sandy loam; 5-39 cm, yellowish-brown sandy loam; $39-41 \mathrm{~cm}+$, strong brown sandy clay

ST $38 \quad 0-5 \mathrm{~cm}$, dark grayish-brown sandy loam; 5-100 cm+, yellowish-brown sandy loam with strong brown mottles

ST 39 0-5 cm, dark grayish-brown sandy loam; 5-45 cm, yellowish-brown sandy loam; 45-46 cm+, strong brown sandy clay

ST $40 \quad$ 0-36 cm, yellowish-brown sandy loam; 36-40 cm+, strong brown sandy clay

ST $41 \quad 0-5 \mathrm{~cm}$, dark grayish-brown sandy loam; 5-16 cm, yellowish-brown sandy loam; $16-17 \mathrm{~cm}+$, yellowish-red clay

ST 42 0-5 cm, dark grayish-brown sandy loam; 5-50 cm, yellowish-brown sandy loam; 50-54 cm+, strong brown sandy clay

ST $43 \quad 0-47 \mathrm{~cm}$, yellowish-brown sandy loam; 47-49 cm+, strong brown sandy clay

ST $44 \quad 0-5 \mathrm{~cm}$, dark grayish-brown sandy loam; 5-40 cm, yellowish-brown sandy loam; 40-42 cm+, strong brown sandy clay

ST 45 0-5 cm, dark grayish-brown sandy loam; 5-50 cm, yellowish-brown sandy loam; 50-55 cm+, strong brown sandy clay

ST 46 0-5 cm, dark grayish-brown sandy loam; 5-39 cm, yellowish-brown sandy loam; $39-41 \mathrm{~cm}+$, strong brown sandy clay

ST $47 \quad 0-51 \mathrm{~cm}$, yellowish-brown sandy loam; 51-53 cm+, strong brown sandy clay

ST $48 \quad$ 0-36 cm, yellowish-brown sandy loam; 36-39 cm+, strong brown sandy clay

ST $49 \quad$ 0-25 cm, yellowish-brown sandy loam; 25-35 cm+, strong brown sandy clay

ST $50 \quad$ 0-5 cm, dark grayish-brown sandy loam; 34-36 cm+, strong brown sandy clay

ST 51 0-5 cm, dark grayish-brown sandy loam; 5-27 cm, yellowish-brown sandy loam; 27-30 cm+, yellowish-red clay

ST $52 \quad$ 0-28 cm, yellowish-brown sandy loam; 28-31 cm+, strong brown sandy clay

ST $53 \quad 0-5 \mathrm{~cm}$, dark grayish-brown sandy loam; 5-40 cm, yellowish-brown sandy loam; 40-43 cm+, yellowish-red clay

ST 54 0-10 cm, dark grayish-brown sandy loam; 10-35 cm, yellowish-brown sandy loam; 35-38 cm+, strong brown sandy clay

ST 55 0-10 cm, dark grayish-brown sandy loam; 10-40 cm, yellowish-brown sandy loam; 40-45 cm+, strong brown sandy clay

ST 56 0-10 cm, dark grayish-brown sandy loam; 10-35 cm, yellowish-brown sandy loam; 35-37 cm+, strong brown sandy clay 
ST 57 0-5 cm, dark grayish-brown sandy loam; 5-36 cm, yellowish-brown sandy loam; 36-45 cm+, strong brown sandy clay

ST $58 \quad 0-40 \mathrm{~cm}$, yellowish-brown sandy loam; 40-42 cm+, strong brown sandy clay

ST 59 0-5 cm, dark grayish-brown sandy loam; 5-24 cm, yellowish-brown sandy loam; 24-30 cm+, yellowish-red clay

ST $60 \quad 0-27 \mathrm{~cm}$, yellowish-brown sandy loam; 27-29 cm+, strong brown sandy clay

ST $61 \quad 0-39 \mathrm{~cm}$, yellowish-brown sandy loam; 39-40 cm+, strong brown sandy clay

ST 62 0-5 cm, dark grayish-brown sandy loam; 5-35 cm, yellowish-brown sandy loam; 35-38 cm+, strong brown sandy clay

ST 63 0-5 cm, dark grayish-brown sandy loam; 5-37 cm, yellowish-brown sandy loam; 37-45 cm+, strong brown sandy clay

ST 64 0-5 cm, dark grayish-brown sandy loam; 5-41 cm, yellowish-brown sandy loam; 41-44 cm+, strong brown sandy clay

ST 65 0-7 cm, dark grayish-brown sandy loam; 7-69 cm, yellowish-brown sandy loam; 69-70 cm+, yellowish-red clay

ST $66 \quad$ 0-10 cm, dark grayish-brown sandy loam; 10-37 cm, grayish-brown sandy loam with strong brown mottles; 37-39 cm+, strong brown clay

ST 67 0-5 cm, dark grayish-brown sandy loam; 5-28 cm, yellowish-brown sandy loam; 28-34 cm+, strong brown sandy clay

ST 68 0-5 cm, dark grayish-brown sandy loam; 5-38 cm, yellowish-brown sandy loam; 38-40 cm+, strong brown sandy clay

ST 69 0-5 cm, dark grayish-brown sandy loam; 5-33 cm, yellowish-brown sandy loam; 33-36 cm+, yellowish-red clay

ST 70 0-10 cm, dark grayish-brown sandy loam; 10-32 cm, yellowish-brown sandy loam; $32-35 \mathrm{~cm}+$, strong brown sandy clay

ST 71 0-5 cm, dark grayish-brown sandy loam; 5-27 cm, yellowish-brown sandy loam; 27-30 cm+, red clay

ST $72 \quad 0-33 \mathrm{~cm}$, yellowish-brown sandy loam; $33-36 \mathrm{~cm}+$, strong brown sandy clay

ST 73 0-5 cm, dark grayish-brown sandy loam; 5-27 cm, yellowish-brown sandy loam; 27-34 cm+, red clay

ST $74 \quad$ 0-20 cm, yellowish-brown sandy loam; $20-22 \mathrm{~cm}+$, strong brown sandy clay

ST 75 0-5 cm, dark grayish-brown sandy loam; 5-20 cm, yellowish-brown sandy loam; 20-26 cm+, red clay

ST 76 0-13 cm, dark grayish-brown sandy loam; 13-21 cm+, red clay

ST 77 0-11 cm, very dark grayish-brown sandy loam; 11-14 cm+, red clay

ST 78 0-24 cm, yellowish-brown sandy loam; $24-26 \mathrm{~cm}+$, red clay 
ST 79 0-5 cm, very dark grayish-brown sandy loam; 5-20 cm, dark yellowish-brown sandy loam; 20-22 $\mathrm{cm}+$, red clay

ST $80 \quad 0-5 \mathrm{~cm}$, very dark grayish-brown sandy loam; 5-37 cm, dark yellowish-brown sandy loam; 37-40 $\mathrm{cm}+$, red clay

ST $81 \quad 0-10 \mathrm{~cm}+$, red clay

ST $82 \quad$ 0-5 cm, very dark grayish-brown sandy loam; 5-28 cm, yellowish-brown sandy loam; $28-30 \mathrm{~cm}+$, red clay

ST 83 0-5 cm, very dark grayish-brown sandy loam; 5-20 cm, dark yellowish-brown sandy loam; 20-24 $\mathrm{cm}+$, red clay

ST $84 \quad 0-5 \mathrm{~cm}$, very dark grayish-brown sandy loam; 5-20 cm, yellowish-brown sandy loam; 20-25 cm+, red clay

ST 85 0-5 cm, very dark grayish-brown sandy loam; 5-15 cm, dark yellowish-brown sandy loam; 15-18 $\mathrm{cm}+$, red clay

ST 86 0-10 cm, very dark grayish-brown sandy loam; 10-15 cm, yellowish-brown sandy loam; 15-18 $\mathrm{cm}+$, red clay

ST $87 \quad 0-5 \mathrm{~cm}$, very dark grayish-brown sandy loam; 5-16 cm, dark yellowish-brown sandy loam; 16-19 $\mathrm{cm}+$, red clay

ST $88 \quad 0-20 \mathrm{~cm}$, yellowish-brown sandy loam; 20-22 cm+, red clay

ST $89 \quad$ 0-7 cm, very dark grayish-brown sandy loam; 7-19 cm, dark yellowish-brown sandy loam; 19-22 $\mathrm{cm}+$, red clay

ST $90 \quad$ 0-10 cm, very dark grayish-brown sandy loam; 10-30 cm, yellowish-brown sandy loam; 30-32 $\mathrm{cm}+$, red clay

ST $91 \quad 0-10 \mathrm{~cm}$, very dark grayish-brown sandy loam; 10-17 cm, yellowish-brown sandy loam; 17-20 $\mathrm{cm}+$, red clay

ST $92 \quad$ 0-10 cm, very dark grayish-brown sandy loam; 10-25 cm, yellowish-brown sandy loam; 25-28 $\mathrm{cm}+$, red clay

ST 93 0-5 cm, very dark grayish-brown sandy loam; 5-18 cm, yellowish-brown sandy loam; 18-21 cm+, red clay

ST $94 \quad$ 0-10 cm, very dark grayish-brown sandy loam; 10-28 cm, yellowish-brown sandy loam; 28-30 $\mathrm{cm}+$, red clay

ST 95 0-5 cm, very dark grayish-brown sandy loam; 5-47 cm, yellowish-brown sandy loam; 47-49 cm+, strong brown clay

ST 96 0-5 cm, very dark grayish-brown sandy loam; 5-27 cm, yellowish-brown sandy loam; 27-29 cm+, red clay

ST $97 \quad 0-38 \mathrm{~cm}$, yellowish-brown sandy loam; 38-39 cm+, strong brown clay

ST $98 \quad$ 0-26 cm, yellowish-brown sandy loam; 26-29 cm+, red clay 
0-5 cm, very dark grayish-brown sandy loam; 5-10 cm, yellowish-brown sandy loam; 10-13 cm+, red clay

ST $100 \quad 0-17 \mathrm{~cm}$, yellowish-brown sandy loam; 17-19 cm+, red clay

ST 101 0-19 cm, dark grayish-brown sandy loam; 19-62 m, yellowish-brown sandy loam; 62-63 cm+, red clay

ST 102 0-10 cm, dark grayish-brown sandy loam; 10-30 cm, yellowish-brown sandy loam; 30-33 cm+, red clay; historic artifacts in the dark grayish-brown and yellowish-brown sandy loam zones (Site \#2, 41RK606)

ST 103 0-6 cm, very dark grayish-brown sandy loam; 6-16 cm, yellowish-brown sandy loam; 16-20 cm+, red clay

ST 104 0-5 cm, dark grayish-brown sandy loam; 5-15 cm, yellowish-brown sandy loam; 15-18 cm+, red clay

ST 105 0-10 cm, very dark grayish-brown sandy loam; 10-30 cm, yellowish-brown sandy loam; 30-33 $\mathrm{cm}+$, red clay

ST 106 0-10 cm, very dark grayish-brown sandy loam; 10-33 cm, yellowish-brown sandy loam; 33-35 $\mathrm{cm}+$, red clay; historic artifacts in the very dark grayish-brown and yellowish-brown sandy loam zones (Site \#2, 41RK606)

ST 107 0-5 cm, very dark grayish-brown sandy loam; 5-15 cm, yellowish-brown sandy loam; 15-18 cm+, red clay

ST 108 0-5 cm, very dark grayish-brown sandy loam; 5-13 cm, yellowish-brown sandy loam; 13-15 cm+, red clay; historic artifacts in the very dark grayish-brown and yellowish-brown sandy loam zones (Site \#2, 4lRK606)

ST 109 0-5 cm, very dark grayish-brown sandy loam; 5-18 cm, yellowish-brown sandy loam; 18-21 cm+, red clay; historic artifacts in the dark grayish-brown and yellowish-brown sandy loam zones (Site \#2, 41RK606)

ST 110 0-10 cm, very dark grayish-brown sandy loam; 10-28 cm, yellowish-brown sandy loam; 28-30 $\mathrm{cm}+$, red clay

ST 111 0-5 cm, very dark grayish-brown sandy loam; 5-38 cm, yellowish-brown sandy loam; 38-40 cm+, red clay; historic artifacts in the dark grayish-brown and yellowish-brown sandy loam zones and prehistoric artifacts in the yellowish-brown sandy loam zone (Site \#2, 41RK606)

ST 112 0-10 cm, very dark grayish-brown sandy loam; 10-13 cm+, red clay

ST $113 \quad 0-15 \mathrm{~cm}+$, red clay

ST $114 \quad 0-10 \mathrm{~cm}+$, red clay

ST 115 0-10 cm, very dark grayish-brown sandy loam; 10-12 cm+, red clay

ST 116 0-5 cm, very dark grayish-brown sandy loam; 5-10 cm+, red clay

ST $117 \quad 0-5 \mathrm{~cm}+$, red clay 
ST 118

ST 119

ST 120

ST 121

ST 122

ST 123

ST 124

ST 125

ST 126

ST 127

ST 128

ST 129

ST 130

ST 131

ST 132

ST 133

ST 134

ST 135

ST 136

ST 137

ST 138

ST 139

0-5 cm, very dark grayish-brown sandy loam; 5-10 cm+, red clay

0-10 cm, very dark grayish-brown sandy loam; $10 \mathrm{~cm}+$, sandstone rocks

$0-10 \mathrm{~cm}+$, red clay

0-22 cm, very dark grayish-brown sandy loam; 22-37 cm, yellowish-brown sandy loam; 37-39 $\mathrm{cm}+$, strong brown clay

0-10 cm, very dark grayish-brown sandy loam; 10-15 cm+, red clay

0-15 cm, yellowish-brown sandy loam; $15-17 \mathrm{~cm}+$, strong brown clay

0-14 cm, dark grayish-brown sandy loam; 14-55 cm, yellowish-brown sandy loam; 55-58 cm+, strong brown clay

0-10 cm+, disturbed sediments with concrete chunks and pavement

0-5 cm, dark grayish-brown sandy loam; 5-30 cm, yellowish-brown sandy loam; 30-33 cm+, yellowish-brown clay

0-20 cm+, disturbed sediments with concrete chunks and pavement

0-10 cm, dark grayish-brown sandy loam; 10-20 cm, yellowish-brown sandy loam; 20-23 cm+, yellowish-brown clay

0-12 cm+, disturbed sediments with concrete chunks and pavement

0-10 cm, dark grayish-brown sandy loam; 10-25 cm, yellowish-brown sandy loam; $25-28 \mathrm{~cm}+$, yellowish-brown clay

0-35 cm, disturbed sediments with concrete chunks and pavement; $35 \mathrm{~cm}+$, strong brown clay

0-10 cm, dark grayish-brown sandy loam; 10-40 cm, yellowish-brown sandy loam; 40-42 cm+, yellowish-brown clay

0-38 cm, yellowish-brown sandy loam; 38-40 cm+, yellowish-brown clay

0-10 cm, dark grayish-brown sandy loam, with charcoal; 10-31 cm, yellowish-brown sandy loam;

31-35 cm+, yellowish-brown clay; historic artifacts in the dark grayish-brown and yellowishbrown sandy loam zones (41RK66)

0-5 cm, dark grayish-brown sandy loam; 5-29 cm, yellowish-brown sandy loam; 29-30 cm+, yellowish-brown clay

0-10 cm, dark grayish-brown sandy loam, with charcoal; 10-35 cm, yellowish-brown sandy loam; 35-38 cm+, yellowish-brown clay

0-5 cm, dark grayish-brown sandy loam; 5-30 cm, yellowish-brown sandy loam; 30-32 cm+, yellowish-brown clay; historic artifacts in the dark grayish-brown and yellowish-brown sandy loam zones (4lRK66)

0-5 cm, dark grayish-brown sandy loam; 5-36 cm, yellowish-brown sandy loam; 36-39 cm+, yellowish-brown clay

0-5 cm, dark grayish-brown sandy loam; 5-32 cm, yellowish-brown sandy loam; 32-34 cm+, yellowish-brown clay 

yellowish-brown clay

ST 141 0-5 cm, dark grayish-brown sandy loam; 5-22 cm, yellowish-brown sandy loam; 22-24 cm+, yellowish-brown clay; historic artifacts in the dark grayish-brown and yellowish-brown sandy loam zones (41RK66)

ST 142 0-5 cm, dark grayish-brown sandy loam; 5-23 cm, yellowish-brown sandy loam; 23-26 cm+, yellowish-brown clay

ST $143 \quad$ 0-40 cm, yellowish-brown sandy loam; $40 \mathrm{~cm}+$, yellowish-brown clay

ST 144 0-5 cm, dark grayish-brown sandy loam; 5-28 cm, yellowish-brown sandy loam; $28-30 \mathrm{~cm}+$, yellowish-brown clay

ST 145 0-5 cm, dark grayish-brown sandy loam; 5-33 cm, yellowish-brown sandy loam; 33-35 cm+, yellowish-brown clay

ST 146 0-5 cm, dark grayish-brown sandy loam; 5-29 cm, yellowish-brown sandy loam; 29-31 cm+, yellowish-brown clay

ST 147 0-28 cm, yellowish-brown sandy loam; 28-29 cm+, yellowish-brown clay

ST 148 0-10 cm, dark grayish-brown sandy loam; 10-25 cm, yellowish-brown sandy loam; $25-27 \mathrm{~cm}+$, yellowish-brown clay

ST 149 0-40 cm, yellowish-brown sandy loam; 40-42 cm+, yellowish-brown clay

ST $150 \quad$ 0-30 cm, yellowish-brown sandy loam; 30-32 cm+, yellowish-brown clay

ST $151 \quad 0-10 \mathrm{~cm}+$, yellowish-brown clay

ST 152 0-25 cm, yellowish-brown sandy loam; 25-28 cm+, yellowish-brown clay

ST 153 0-5 cm, dark grayish-brown sandy loam; 5-26 cm, dark reddish-brown sandy loam; $26 \mathrm{~cm}+$, sandstone rocks

ST 154 0-22 cm, yellowish-brown sandy loam; 22-24 cm+, yellowish-brown clay

ST $155 \quad$ 0-7 cm, dark grayish-brown sandy loam; $7 \mathrm{~cm}+$, strong brown clay

ST 156 0-25 cm, dark yellowish-brown sandy loam; 25-27 cm+, strong brown clay

ST 157 0-19 cm, yellowish-brown sandy loam; 19-21 cm+, yellowish-brown clay

ST 158 0-55 cm, yellowish-brown sandy loam; 55-57 cm+, yellowish-brown clay; historic artifacts in the yellowish-brown sandy loam zone (Site \#3, 41RK607)

ST 159 0-5 cm, dark grayish-brown sandy loam; 5-34 cm, dark yellowish-brown sandy loam with red clay mottles; 34-50 cm+, yellowish-brown clay; historic artifacts in the yellowish-brown sandy loam zone (Site \#3, 41RK607)

ST 160 0-44 cm, yellowish-brown sandy loam; 44-46 cm+, yellowish-brown clay

ST $161 \quad 0-47 \mathrm{~cm}$, yellowish-brown sandy loam; 47-48 cm+, yellowish-brown clay; historic artifacts in the yellowish-brown sandy loam zone (Site \#3, 41RK607) 
ST $163 \quad 0-38 \mathrm{~cm}+$, disturbed sediments with concrete chunks

ST 164 0-36 cm, yellowish-brown sandy loam; 36-40 cm+, yellowish-brown clay; historic artifacts in the yellowish-brown sandy loam zone (Site \#3, 41RK607)

ST 165 0-5 cm, dark grayish-brown sandy loam; 5-42 cm, yellowish-brown sandy loam; 42-43 cm+, yellowish-brown clay

ST 166 0-5 cm, dark grayish-brown sandy loam; 5-27 cm, yellowish-brown sandy loam; 27-31 cm+, yellowish-brown clay

ST 167 0-6 cm, dark grayish-brown sandy loam; 6-50 cm, yellowish-brown sandy loam; 50-52 cm+, yellowish-brown clay

ST 168 0-5 cm, dark grayish-brown sandy loam; 5-39 cm, yellowish-brown sandy loam; 39-4l cm+, yellowish-brown clay

ST 169 0-27 cm, yellowish-brown sandy loam; 27-29 cm+, yellowish-brown clay

ST 170 0-10 cm, dark grayish-brown sandy loam; 10-44 cm, yellowish-brown sandy loam; 44-46 cm+, yellowish-brown clay

ST $1710-38 \mathrm{~cm}$, disturbed sediments with concrete fragments; $38-40 \mathrm{~cm}+$, yellowish-brown clay

ST 172 0-5 cm, dark grayish-brown sandy loam; 5-34 cm, yellowish-brown sandy loam; 34-36 cm+, strong brown clay

ST 173 0-5 cm, dark grayish-brown sandy loam; 5-42 cm+, disturbed sediments with concrete fragments, charcoal, and pebbles

ST 174 0-10 cm, dark grayish-brown sandy loam; 10-37 cm, yellowish-brown sandy loam; 37-40 cm+, strong brown clay

ST 175 0-12 cm, red clay fill; 12-30 cm, yellowish-brown sandy loam; 30-33 cm+, yellowish-brown clay

ST 176 0-10 cm, dark grayish-brown sandy loam; 10-35 cm, yellowish-brown sandy loam; 35-39 cm+, strong brown clay

ST $177 \quad 0-30 \mathrm{~cm}$, disturbed sediments with red clay chunks; $30-33 \mathrm{~cm}+$, yellowish-brown clay

ST 178 0-5 cm, dark grayish-brown sandy loam; 5-29 cm, yellowish-brown sandy loam; 29-31 cm+, strong brown clay; historic artifacts in the dark grayish-brown and yellowish-brown sandy loam zones (4lRK66)

ST $179 \quad 0-38 \mathrm{~cm}$, disturbed sediments with red clay and concrete chunks; 38-40 cm+, yellowish-brown clay

ST 180 0-10 cm, dark grayish-brown sandy loam; 10-24 cm, yellowish-brown sandy loam; 24-26 cm+, strong brown clay; historic artifacts in the dark grayish-brown and yellowish-brown sandy loam zones (4lRK66)

ST 181 0-10 cm, dark grayish-brown sandy loam; 10-30 cm, yellowish-brown sandy loam; 30-33 cm+, strong brown clay 
0-10 cm, dark grayish-brown sandy loam with charcoal; 10-34 cm, yellowish-brown sandy loam; 34-36 cm+, strong brown clay; historic artifacts in the dark grayish-brown and yellowish-brown sandy loam zones (41RK66)

ST 183 0-5 cm, dark grayish-brown sandy loam; 5-25 cm, yellowish-brown sandy loam; 25-27 cm+, strong brown clay

ST 184 0-5 cm, dark grayish-brown sandy loam; 5-25 cm, yellowish-brown sandy loam; 25-28 cm+, strong brown clay

ST 185 0-12 cm, very dark grayish-brown sandy loam; 12-15 cm+, red clay

ST 186 0-5 cm, dark grayish-brown sandy loam; 5-30 cm, yellowish-brown sandy loam; 30-33 cm+, strong brown clay

ST 187 0-5 cm, dark grayish-brown sandy loam; 5-20 cm, yellowish-brown sandy loam; 20-23 cm+, yellowish-brown clay

ST 188 0-5 cm, dark grayish-brown sandy loam; 5-23 cm, yellowish-brown sandy loam; 23-25 cm+, strong brown clay

ST 189 0-5 cm, dark grayish-brown sandy loam; 5-36 cm, yellowish-brown sandy loam; 36-37 cm+, yellowish-brown clay

ST 190 0-10 cm, dark grayish-brown sandy loam with charcoal; 10-36 cm, yellowish-brown sandy loam; $36-39 \mathrm{~cm}+$, strong brown clay

ST 191 0-23 cm, yellowish-brown sandy loam; 23-25 cm+, yellowish-brown clay

ST 192 0-5 cm, dark grayish-brown sandy loam; 5-18 cm, yellowish-brown sandy loam; 18-20 cm+, strong brown clay

ST 193 0-5 cm, dark grayish-brown sandy loam; 5-28 cm, yellowish-brown sandy loam; 28-29 cm+, yellowish-brown clay

ST 194 0-5 cm, dark grayish-brown sandy loam; 5-10 cm+, strong brown clay

ST 195 0-5 cm, dark grayish-brown sandy loam; 5-25 cm, yellowish-brown sandy loam; 25-28 cm+, yellowish-brown clay

ST 196 0-10 cm, dark grayish-brown sandy loam with charcoal; 10-37 cm, yellowish-brown sandy loam; $37-40 \mathrm{~cm}+$, strong brown clay

ST 197 0-5 cm, yellowish-brown sandy loam; 5-8 cm+, strong brown clay

ST 198 0-5 cm, dark grayish-brown sandy loam; 5-17 cm, yellowish-brown sandy loam; 17-20 cm+, strong brown clay

ST 199 0-12 cm, yellowish-brown sandy loam; 12-15 cm+, strong brown clay

ST 200 0-5 cm, dark grayish-brown sandy loam; 5-25 cm, yellowish-brown sandy loam; 25-28 cm+, strong brown clay

ST 201 0-6 cm, dark grayish-brown sandy loam; 6-23 cm, yellowish-brown sandy loam; 23-26 cm+, yellowish-brown clay 
0-10 cm, dark grayish-brown sandy loam; $10-30 \mathrm{~cm}$, yellowish-brown sandy loam; $30-31 \mathrm{~cm}+$, strong brown clay

ST 203 0-21 cm, yellowish-brown sandy loam; 21-24 cm+, strong brown clay

ST $204 \quad 0-15 \mathrm{~cm}+$, strong brown clay

ST $205 \quad$ 0-49 cm, yellowish-brown sandy loam; 49-50 cm+, yellowish-brown clay

ST $206 \quad 0-10 \mathrm{~cm}+$, strong brown clay

ST 207 0-7 cm, dark grayish-brown sandy loam; 7-34 cm, yellowish-brown sandy loam; 34-36 cm+, yellowish-brown clay

ST $208 \quad$ 0-18 cm, yellowish-brown sandy loam; 18-20 cm+, strong brown clay

ST 209 0-5 cm, dark grayish-brown sandy loam; 5-32 cm, yellowish-brown sandy loam; 32-33 cm+, yellowish-brown clay

ST 210 0-15 cm, yellowish-brown sandy loam; 15-18 cm+, strong brown clay

ST 211 0-5 cm, dark grayish-brown sandy loam; 5-23 cm, yellowish-brown sandy loam; 23-26 cm+, yellowish-brown clay

ST 212 0-10 cm, dark grayish-brown sandy loam; 10-39 cm, yellowish-brown sandy loam; $39-41 \mathrm{~cm}+$, strong brown clay

ST 213 0-6 cm, dark grayish-brown sandy loam; 6-28 cm, yellowish-brown sandy loam; $28-30 \mathrm{~cm}+$, yellowish-brown clay

ST $214 \quad$ 0-28 cm, yellowish-brown sandy loam; $28-30 \mathrm{~cm}+$, strong brown clay

ST 215 0-5 cm, dark grayish-brown sandy loam; 5-51 cm, yellowish-brown sandy loam; 51-53 cm+, yellowish-brown clay

ST $216 \quad 0-10 \mathrm{~cm}$, dark grayish-brown sandy loam; 10-23 cm, yellowish-brown sandy loam; $23-25 \mathrm{~cm}+$, strong brown clay

ST 217 0-8 cm, dark grayish-brown sandy loam; 8-45 cm, yellowish-brown sandy loam; 45-47 cm+, yellowish-brown clay

ST $218 \quad$ 0-20 cm, yellowish-brown sandy loam; 20-22 cm+, strong brown clay

ST 219 0-5 cm, dark grayish-brown sandy loam; 5-58 cm, yellowish-brown sandy loam; 58-60 cm+, yellowish-brown clay

ST $220 \quad 0-27 \mathrm{~cm}$, yellowish-brown sandy loam; 27-29 cm+, strong brown clay

ST $221 \quad$ 0-27 cm, yellowish-brown sandy loam; 27-30 cm+, strong brown clay

ST 222 0-32 cm, yellowish-brown sandy loam; 32-34 cm+, strong brown clay

ST $223 \quad$ 0-33 cm, yellowish-brown sandy loam; 33-36 cm+, strong brown clay

ST 224 0-15 cm, yellowish-brown loam; 15-20 cm+, strong brown clay

ST $225 \quad 0-41 \mathrm{~cm}$, light grayish-brown sandy loam with strong brown mottles and manganese concretions; $41-43 \mathrm{~cm}+$, strong brown clay 
0-5 cm, dark grayish-brown sandy loam; 5-40 cm, yellowish-brown sandy loam; 40-43 cm+, strong brown clay

ST 227 0-5 cm, dark grayish-brown sandy loam; 5-60 cm, yellowish-brown sandy loam; 60-62 cm+, strong brown clay

ST $228 \quad 0-43 \mathrm{~cm}$, yellowish-brown sandy loam with strong brown mottles; 43-45 cm+, strong brown clay

ST 229 0-5 cm, dark grayish-brown sandy loam; 5-50 cm, yellowish-brown sandy loam; 50-53 cm+, strong brown clay; prehistoric lithic artifacts in the yellowish-brown sandy loam zone (Isolated Find)

ST $230 \quad 0-43 \mathrm{~cm}$, yellowish-brown sandy loam; 43-46 cm+, strong brown clay

ST 231 0-18 cm, light yellowish-brown sandy loam; 18-60 cm, yellowish-brown sandy loam; $60 \mathrm{~cm}+$, strong brown clay

ST 232 0-56 cm, yellowish-brown sandy loam; 56-59 cm+, strong brown clay

ST 233 0-6 cm, dark grayish-brown sandy loam; 6-25 cm, light yellowish-brown sandy loam with strong brown mottles; $25-43 \mathrm{~cm}$, yellowish-brown sandy loam; 43-45 cm+, strong brown clay

ST 234 0-10 cm, dark grayish-brown sandy loam; 10-36 cm, yellowish-brown sandy loam with strong brown mottles; 36-39 cm+, strong brown clay

ST 235 0-10 cm, dark grayish-brown sandy loam; 10-32 cm, yellowish-brown sandy loam; 32-35 cm+, strong brown clay

ST $236 \quad 0-29 \mathrm{~cm}$, yellowish-brown sandy loam with strong brown mottles; $29-31 \mathrm{~cm}+$, strong brown clay

ST 237 0-5 cm, dark grayish-brown sandy loam; 5-30 cm, dark yellowish-brown sandy loam; 30-63 cm, yellowish-brown sandy loam; 63-65 cm+, strong brown clay

ST $238 \quad 0-20 \mathrm{~cm}$, yellowish-brown sandy loam with strong brown mottles; $20-40 \mathrm{~cm}$, yellowish-brown sandy loam; $40 \mathrm{~cm}+$, strong brown clay

ST $239 \quad$ 0-53 cm, yellowish-brown sandy loam; 53-55 cm+, strong brown clay

ST 240 0-10 cm, very dark grayish-brown sandy loam; 10-35 cm, yellowish-brown sandy loam with strong brown mottles; 35-38 cm+, strong brown clay

ST $241 \quad$ 0-10 cm, dark grayish-brown sandy loam; 10-29 cm, yellowish-brown sandy loam with strong brown mottles; $29-40 \mathrm{~cm}$, yellowish-brown sandy loam; $40 \mathrm{~cm}+$, strong brown clay

ST 242 0-34 cm, yellowish-brown sandy loam; 34-36 cm+, strong brown clay

ST 243 0-10 cm, dark grayish-brown sandy loam; 10-20 cm, yellowish-brown sandy loam with strong brown mottles; $20 \mathrm{~cm}+$, strong brown clay

ST $244 \quad$ 0-48 cm, yellowish-brown sandy loam; 48-50 cm+, strong brown clay

ST 245 0-5 cm, dark grayish-brown sandy loam; 5-63 cm, yellowish-brown sandy loam; 63-65 cm+, strong brown clay

ST 246 0-5 cm, dark grayish-brown sandy loam; 5-52 cm, yellowish-brown sandy loam; 52-54 cm+, strong brown clay 
ST 247 0-5 cm, dark grayish-brown sandy loam; 5-40 cm, yellowish-brown sandy loam; 40-42 cm+, strong brown clay

ST 248 0-5 cm, dark grayish-brown sandy loam; 5-50 cm, yellowish-brown sandy loam; 50-52 cm+, strong brown clay

ST 249 0-13 cm, dark grayish-brown sandy loam; 13-29 cm, yellowish-brown sandy loam; 29-32 cm+, strong brown clay

ST 250 0-5 cm, dark grayish-brown sandy loam; 5-35 cm, yellowish-brown sandy loam; 35-37 cm+, strong brown clay

ST 251 0-15 cm, yellowish-brown sandy loam; 15-28 cm, yellowish-brown sandy loam with strong brown mottles; 28-30 cm+, strong brown clay

ST $252 \quad$ 0-25 cm, yellowish-brown sandy loam; 25-33 cm, yellowish-brown sandy loam with strong brown mottles; 33-35 cm+, strong brown clay

ST 253 0-10 cm, very dark grayish-brown sandy loam; 10-25 cm, yellowish-brown sandy loam with strong brown mottles; $25 \mathrm{~cm}+$, strong brown clay

ST $254 \quad$ 0-30 cm, yellowish-brown sandy loam; 30-32 cm+, strong brown clay

ST 255 0-10 cm, dark grayish-brown sandy loam; 10-55 cm, yellowish-brown sandy loam; 55-56 cm+, strong brown clay

ST $256 \quad 0-60 \mathrm{~cm}+$, lignite fill

ST $257 \quad 0-39 \mathrm{~cm}$, gray clay and lignite fill; $39 \mathrm{~cm}+$, lignite fill

ST $258 \quad 0-40 \mathrm{~cm}+$, gray clay and lignite fill

ST $259 \quad 0-40 \mathrm{~cm}+$, gray clay and lignite fill

ST $260 \quad 0-40 \mathrm{~cm}+$, gray clay and lignite fill

ST $261 \quad 0-30 \mathrm{~cm}+$, gray clay and lignite fill

ST $262 \quad 0-30 \mathrm{~cm}+$, gray clay and lignite fill

ST $263 \quad 0-30 \mathrm{~cm}+$, gray clay and lignite fill

ST $264 \quad 0-30 \mathrm{~cm}+$, gray clay with lignite fill

ST 265 0-5 cm, dark grayish-brown sandy loam; 5-29 cm, yellowish-brown sandy loam; 29-31 cm+, strong brown clay

ST $266 \quad 0-20 \mathrm{~cm}+$, gray clay and lignite fill

ST 267 0-5 cm, dark grayish-brown sandy loam; 5-32 cm, yellowish-brown sandy loam; 32-34 cm+, strong brown clay

ST 268 0-10 cm, dark grayish-brown sandy loam; 10-27 cm, yellowish-brown loam; 27-30 cm+, strong brown clay

ST 269 0-5 cm, dark grayish-brown sandy loam; 5-30 cm, yellowish-brown sandy loam; 30-33 cm+, strong brown clay 
ST $271 \quad 0-5 \mathrm{~cm}$, dark grayish-brown sandy loam; 5-35 cm, yellowish-brown sandy loam; 35-37 cm+, strong brown clay

ST $272 \quad 0-30 \mathrm{~cm}$, yellowish-brown sandy loam; 30-33 cm+, strong brown clay

ST 273 0-6 cm, dark grayish-brown sandy loam; 6-48 cm, yellowish-brown sandy loam; 48-50 cm+, strong brown clay

ST $274 \quad$ 0-36 cm, yellowish-brown sandy loam; 36-38 cm+, strong brown clay

ST 275 0-30 cm, yellowish-brown sandy loam; 30-73 cm, dark yellowish-brown sandy loam with strong brown lamellae; 73-75 cm+, strong brown clay

ST 276 0-24 cm, yellowish-brown sandy loam; 24-26 cm+, strong brown clay

ST 277 0-5 cm, dark grayish-brown sandy loam; 5-40 cm, yellowish-brown sandy loam; 40-42 cm+, strong brown clay

ST $278 \quad$ 0-38 cm, yellowish-brown sandy loam; 38-40 cm+, strong brown clay

ST 279 0-5 cm, dark grayish-brown sandy loam; 5-29 cm, yellowish-brown sandy loam; 29-30 cm+, strong brown clay

ST $280 \quad$ 0-34 cm, yellowish-brown sandy loam; 34-36 cm+, strong brown clay

ST $281 \quad 0-31 \mathrm{~cm}$, yellowish-brown sandy loam; 31-33 cm+, strong brown clay

ST $282 \quad$ 0-35 cm, yellowish-brown sandy loam; 35-38 cm+, strong brown clay

ST 283 0-5 cm, dark grayish-brown sandy loam; 5-35 cm, yellowish-brown sandy loam; 35-37 cm+, strong brown clay

ST $284 \quad$ 0-58 cm, yellowish-brown sandy loam; 58-60 cm+, strong brown clay

ST 285 0-5 cm, dark grayish-brown sandy loam; 5-25 cm, yellowish-brown sandy loam; 25-28 cm+, strong brown clay

ST $286 \quad 0-15 \mathrm{~cm}+$, strong brown clay

ST 287 0-5 cm, dark grayish-brown sandy loam; 5-40 cm, yellowish-brown sandy loam; 40-42 cm+, strong brown clay

ST $288 \quad 0-30 \mathrm{~cm}+$, gray clay and lignite fill

ST $289 \quad 0-25 \mathrm{~cm}$, disturbed fill; 25-27 cm+, strong brown clay

ST $290 \quad$ 0-30 cm+, gray clay and lignite fill

ST $291 \quad$ 0-25 cm, disturbed fill; 25-30 cm+, strong brown clay

ST $292 \quad 0-25 \mathrm{~cm}+$, gray clay and lignite fill

ST 293 0-27 cm, disturbed sediments; 27-30 cm+, strong brown clay

ST $294 \quad 0-30 \mathrm{~cm}$, disturbed sediments; $30-35 \mathrm{~cm}+$, strong brown clay 
ST $296 \quad 0-30 \mathrm{~cm}$, disturbed sediments; 30-40 cm+, strong brown clay

ST $297 \quad$ 0-50 cm, yellowish-brown sandy loam; $50 \mathrm{~cm}+$, red clay

ST 298 0-10 cm, dark grayish-brown sandy loam; 10-13 cm+, red clay

ST 299 0-7 cm, dark grayish-brown sandy loam; 7-35 cm, yellowish-brown sandy loam; 35-37 cm+, strong brown clay

ST $300 \quad$ 0-5 cm, dark grayish-brown sandy loam; 5-8 cm+, red clay

ST 301 0-5 cm, dark grayish-brown sandy loam; 5-22 cm, yellowish-brown sandy loam; 22-24 cm+, strong brown clay

ST 302 0-15 cm, dark grayish-brown sandy loam; 15-20 cm+, red clay

ST 303 0-7 cm, dark grayish-brown sandy loam; 7-20 cm, yellowish-brown sandy loam; 20-23 cm+, strong brown clay

ST 304 0-25 cm, yellowish-brown sandy loam; 25-29 cm+, red clay

ST 305 0-6 cm, dark grayish-brown sandy loam; $6 \mathrm{~cm}+$, red clay

ST $306 \quad 0-27 \mathrm{~cm}$, yellowish-brown sandy loam; $27-30 \mathrm{~cm}+$, red clay

ST $307 \quad 0-5 \mathrm{~cm}$, dark grayish-brown sandy loam; 5-18 cm, yellowish-brown sandy loam; 18-20 cm+, red clay

ST 308 0-15 cm, dark grayish-brown sandy loam; 15-17 cm+, red clay; historic artifacts in the dark grayish-brown sandy loam zone (4lRK69)

ST $309 \quad$ 0-5 cm, dark grayish-brown sandy loam; 5-25 cm, yellowish-brown sandy loam; 25-26 cm+, red clay

ST $310 \quad$ 0-20 cm, dark grayish-brown sandy loam; 20-23 cm+, red clay

ST 311 0-24 cm, dark grayish-brown sandy loam; 24-60 cm, yellowish-brown sandy loam; $60 \mathrm{~cm}+$, red clay

ST 312 0-15 cm, dark grayish-brown sandy loam; 15-17 cm+, red clay

ST 313 0-10 cm, dark grayish-brown sandy loam; 10-12 cm+, red clay

ST 314 0-10 cm, dark grayish-brown sandy loam; 10-15 cm+, red clay

ST 315 0-5 cm, dark grayish-brown sandy loam; 5-30 cm, yellowish-brown sandy loam; 30-32 cm+, red clay

ST $316 \quad$ 0-10 cm, dark grayish-brown sandy loam; 10-24 cm, yellowish-brown sandy loam; $24-26 \mathrm{~cm}+$, red clay

ST $317 \quad 0-27 \mathrm{~cm}$, yellowish-brown sandy loam; $27-28 \mathrm{~cm}+$, red clay

ST 318 0-20 cm, yellowish-brown sandy loam; 20-22 cm+, red clay; historic artifacts in the yellowishbrown sandy loam zone (41RK69) 

grayish-brown sandy loam zone (41RK69)

ST 320 0-5 cm, dark grayish-brown sandy loam; 5-25 cm, yellowish-brown sandy loam; $25-27 \mathrm{~cm}+$, strong brown clay

ST 321 0-6 cm, dark grayish-brown sandy loam; 6-19 cm, reddish-brown sandy loam; 19-20 cm+, red clay; historic artifacts in the dark grayish-brown and reddish-brown sandy loam zones (41RK69)

ST $322 \quad$ 0-23 cm, yellowish-brown sandy loam; 23-26 cm+, strong brown clay

ST $323 \quad 0-17 \mathrm{~cm}$, yellowish-brown sandy loam; 17-19 cm+, red clay

ST 324 0-5 cm, dark grayish-brown sandy loam; 5-17 cm, yellowish-brown sandy loam; 17-20 cm+, strong brown clay

ST 325 0-6 cm, dark grayish-brown sandy loam; 6-10 cm, yellowish-brown sandy loam; 10-22 cm+, red sandy clay with yellowish-brown mottles

ST 326 0-5 cm, dark grayish-brown sandy loam; 5-10 cm+, strong brown clay

ST 327 0-4 cm, dark grayish-brown sandy loam; 4-6 cm+, red clay

ST $328 \quad 0-20 \mathrm{~cm}$, yellowish-brown sandy loam; 20-22 cm+, strong brown clay

ST $329 \quad$ 0-10 cm, dark grayish-brown sandy loam; 10-12 cm+, red clay

ST $330 \quad 0-10 \mathrm{~cm}+$, strong brown clay

ST 331 0-6 cm, dark grayish-brown sandy loam; 6-18 cm, yellowish-brown sandy loam; $18-20 \mathrm{~cm}+$, red clay; historic artifacts in the dark grayish-brown and yellowish-brown sandy loam zones (41RK69)

ST 332 0-15 cm, yellowish-brown sandy loam; 15-17 cm+, strong brown clay

ST 333 0-7 cm, dark grayish-brown sandy loam; 7-12 cm+, red clay; historic artifacts in the dark grayishbrown sandy loam zone (41RK69)

ST 334 0-5 cm, dark grayish-brown sandy loam; 5-22 cm, yellowish-brown sandy loam; 22-25 cm+, strong brown clay

ST 335 0-7 cm, dark grayish-brown sandy loam; 7-29 cm, yellowish-brown sandy loam; $29-30 \mathrm{~cm}+$, strong brown clay

ST $336 \quad$ 0-5 cm, dark grayish-brown sandy loam; 5-28 cm, yellowish-brown sandy loam; $28-30 \mathrm{~cm}+$, strong brown clay

ST $337 \quad 0-37 \mathrm{~cm}$, yellowish-brown sandy loam; 37-38 cm+, red clay

ST $338 \quad 0-27 \mathrm{~cm}$, yellowish-brown sandy loam; 27-29 cm+, strong brown clay

ST 339 0-5 cm, dark grayish-brown sandy loam; 5-38 cm, yellowish-brown sandy loam; 38-39 cm+, strong brown clay

ST $340 \quad 0-15 \mathrm{~cm}$, dark grayish-brown sandy loam; $15-18 \mathrm{~cm}+$, red clay

ST $341 \quad$ 0-8 cm, dark grayish-brown sandy loam; 8-12 cm+, strong brown clay

ST $342 \quad 0-13 \mathrm{~cm}$, dark grayish-brown sandy loam; 13-15 cm+, red clay 
ST 344 0-5 cm, dark grayish-brown sandy loam; 5-18 cm, yellowish-brown sandy loam; 18-20 cm+, strong brown clay

ST 345 0-5 cm, dark grayish-brown sandy loam; 5-20 cm, yellowish-brown sandy loam; 20-22 cm+, strong brown clay

ST $346 \quad 0-10 \mathrm{~cm}+$, red clay

ST 347 0-5 cm, dark grayish-brown sandy loam; 5-37 cm, yellowish-brown sandy loam; 37-39 cm+, strong brown clay

ST $348 \quad$ 0-5 cm, dark grayish-brown sandy loam; 5-17 cm, yellowish-brown sandy loam; 17-19 cm+, red clay

ST 349 0-5 cm, dark grayish-brown sandy loam; 5-25 cm, yellowish-brown sandy loam; 25-28 cm+, strong brown clay

ST $350 \quad$ 0-5 cm, dark grayish-brown sandy loam; 5-22 cm, yellowish-brown sandy loam; 22-24 cm+, strong brown clay

ST $351 \quad$ 0-10 cm, dark grayish-brown sandy loam; 10-15 cm+, red clay

ST 352 0-5 cm, dark grayish-brown sandy loam; 5-19 cm, yellowish-brown sandy loam; 19-21 cm+, strong brown clay

ST $353 \quad$ 0-27 cm, yellowish-brown sandy loam; 27-30 cm+, strong brown clay

ST 354 0-10 cm, dark grayish-brown sandy loam; 10-42 cm, yellowish-brown sandy loam; $42-44 \mathrm{~cm}+$, strong brown clay

ST $355 \quad 0-10 \mathrm{~cm}+$, red clay

ST 356 0-16 cm, dark grayish-brown sandy loam; 16-50 cm, yellowish-brown sandy loam with lamellae; $50-52 \mathrm{~cm}+$, strong brown clay

ST 357 0-5 cm, dark grayish-brown sandy loam; 5-45 cm, yellowish-brown sandy loam; 45-48 cm+, strong brown clay

ST $358 \quad$ 0-5 cm, dark grayish-brown sandy loam with charcoal; 5-26 cm, yellowish-brown sandy loam; $26-28 \mathrm{~cm}+$, strong brown clay

ST $359 \quad$ 0-10 cm, dark grayish-brown sandy loam with charcoal; 10-25 cm, yellowish-brown sandy loam; $25-26 \mathrm{~cm}+$, strong brown clay

ST 360 0-46 cm, yellowish-brown sandy loam; 46-48 cm+, strong brown clay

ST 361 0-10 cm, dark grayish-brown sandy loam; 10-50 cm, yellowish-brown sandy loam; 50-55 cm+, strong brown clay

ST 362 0-29 cm, yellowish-brown sandy loam; 29-31 cm+, strong brown clay

ST 363 0-44 cm, yellowish-brown sandy loam; 44-45 cm+, strong brown clay

ST 364 0-5 cm, dark grayish-brown sandy loam; 5-33 cm, yellowish-brown sandy loam; 33-36 cm+, strong brown clay 
ST $366 \quad 0-5 \mathrm{~cm}$, dark grayish-brown sandy loam; 5-45 cm, yellowish-brown sandy loam; 45-48 cm+, strong brown clay

ST 367 0-5 cm, dark grayish-brown sandy loam; 5-40 cm, yellowish-brown sandy loam; 40-45 cm+, strong brown clay

ST 368 0-10 cm, dark grayish-brown sandy loam; 10-27 cm, yellowish-brown sandy loam; 27-29 cm+, strong brown clay

ST 369 0-5 cm, dark grayish-brown sandy loam; 5-22 cm, yellowish-brown sandy loam; 22-25 cm+, strong brown clay

ST 370 0-5 cm, dark grayish-brown sandy loam; 5-47 cm, yellowish-brown sandy loam; 47-49 cm+, strong brown clay

ST 371 0-5 cm, dark grayish-brown sandy loam; 5-25 cm, yellowish-brown sandy loam; 25-30 cm+, strong brown clay

ST 372 0-33 cm, yellowish-brown sandy loam; 33-35 cm+, strong brown clay

ST 373 0-5 cm, dark grayish-brown sandy loam; 5-40 cm, yellowish-brown sandy loam; $40-44 \mathrm{~cm}+$, strong brown clay; historic artifacts in dark grayish-brown and yellowish-brown sandy loam zones (41RK71)

ST 374 0-5 cm, dark grayish-brown sandy loam; 5-50 cm, yellowish-brown sandy loam; 50-52 cm+, strong brown clay

ST 375 0-7 cm, dark grayish-brown sandy loam; 7-45 cm, yellowish-brown sandy loam; 45-50 cm+, strong brown clay; historic artifacts in dark grayish-brown and yellowish-brown sandy loam zones (41RK71)

ST $376 \quad$ 0-50 cm, yellowish-brown sandy loam; 50-52 cm+, strong brown clay; historic artifacts in yellowish-brown sandy loam zone (4lRK71)

ST 377 0-5 cm, dark grayish-brown sandy loam; 5-45 cm, yellowish-brown sandy loam; 45-47 cm+, strong brown clay

ST 378 0-5 cm, dark grayish-brown sandy loam; 5-52 cm, yellowish-brown sandy loam; 52-54 cm+, strong brown clay

ST 379 0-5 cm, dark grayish-brown sandy loam; 5-50 cm, yellowish-brown sandy loam; 50-53 cm+, strong brown clay; historic artifacts in dark grayish-brown and yellowish-brown sandy loam zones (4lRK71)

ST 380 0-10 cm, dark grayish-brown sandy loam and charcoal; 10-30 cm, yellowish-brown sandy loam; 30-33 cm+, strong brown clay

ST $381 \quad 0-5 \mathrm{~cm}$, dark grayish-brown sandy loam; 5-40 cm, yellowish-brown sandy loam; 40-47 cm+, strong brown clay; historic artifacts in dark grayish-brown and yellowish-brown sandy loam zones (41RK71)

ST $383 \quad 0-36 \mathrm{~cm}$, yellowish-brown sandy loam; 36-37 cm+, strong brown clay 
ST 384

ST 385

ST 386

ST 394

ST 395

ST 396

ST 397

ST 398

ST 399

ST 400

ST 401

ST 402

ST 403

ST 404

ST 405

ST 406

ST 407

ST 408

ST 409

ST 410

ST 411

ST 412

ST 413

ST 414

0-25 cm, yellowish-brown sandy loam; 25-27 cm+, strong brown clay

0-10 cm, dark grayish-brown sandy loam; $10-48 \mathrm{~cm}$, yellowish-brown sandy loam; 48-50 cm+, strong brown clay

0-18 cm, yellowish-brown sandy loam; $18-20 \mathrm{~cm}$, strong brown clay

0-5 cm, dark grayish-brown sandy loam; 5-27 cm, yellowish-brown sandy loam; 27-29 cm+, strong brown clay

0-10 cm, dark grayish-brown sandy loam; 10-32 cm, yellowish-brown sandy loam; $32-34 \mathrm{~cm}+$, strong brown clay

0-17 cm, yellowish-brown sandy loam; 17-20 cm+, strong brown clay

0-5 cm, dark grayish-brown sandy loam; 5-43 cm, yellowish-brown sandy loam; 43-44 cm+, strong brown clay

0-15 cm, yellowish-brown sandy loam; $15-17 \mathrm{~cm}+$, strong brown clay

0-10 cm, dark grayish-brown sandy loam; 10-52 cm, yellowish-brown sandy loam; $52-54 \mathrm{~cm}+$, strong brown clay

0-10 cm, very dark grayish-brown sandy loam; 10-13 cm+, red clay

0-5 cm, dark grayish-brown sandy loam; 5-15 cm, yellowish-brown sandy loam; 15-18 cm+, strong brown clay

0-10 cm, dark grayish-brown sandy loam; $10-36 \mathrm{~cm}$, yellowish-brown sandy loam; $36-39 \mathrm{~cm}+$, strong brown clay

0-10 cm+, red clay

0-10 cm, dark grayish-brown sandy loam; 10-22 cm, yellowish-brown sandy loam; $22-24 \mathrm{~cm}+$, red clay

0-20 cm, yellowish-brown sandy loam; $20-23 \mathrm{~cm}+$, strong brown clay

0-15 cm, yellowish-brown sandy loam; 15-18 cm+, red clay

0-18 cm, yellowish-brown sandy loam; $18-21 \mathrm{~cm}+$, red clay

0-5 cm, dark grayish-brown sandy loam; 5-18 cm, yellowish-brown sandy loam; 18-20 cm+, yellowish-brown sandy clay

0-22 cm, yellowish-brown sandy loam; $22-24 \mathrm{~cm}+$, strong brown clay

0-5 cm, dark grayish-brown sandy loam; 5-17 cm, yellowish-brown sandy loam; 17-19 cm+, strong brown clay

0-11 cm, dark grayish-brown sandy loam; 11-14 cm+, strong brown clay

0-12 cm, very dark grayish-brown sandy loam; 12-14 cm+, red clay

0-10 cm, dark grayish-brown sandy loam; 10-28 cm, yellowish-brown sandy loam; $28-31 \mathrm{~cm}+$, strong brown clay

0-20 cm, yellowish-brown sandy loam; 20-22 cm+, strong brown clay 
ST $415 \quad 0-10 \mathrm{~cm}$, very dark grayish-brown sandy loam; 10-13 cm+, red clay

ST $416 \quad 0-23 \mathrm{~cm}$, yellowish-brown sandy loam; 23-25 cm+, strong brown clay

ST 417 0-10 cm, dark grayish-brown sandy loam; 10-41 cm, yellowish-brown sandy loam; $41-44 \mathrm{~cm}+$, strong brown clay

ST $418 \quad 0-15 \mathrm{~cm}$, dark grayish-brown sandy loam; $15-18 \mathrm{~cm}+$, red clay

ST $419 \quad 0-27 \mathrm{~cm}$, yellowish-brown sandy loam; 27-31 cm+, strong brown clay

ST 420 0-5 cm, dark grayish-brown sandy loam; 5-21 cm, yellowish-brown sandy loam; 21-24 cm+, strong brown clay

ST $421 \quad 0-17 \mathrm{~cm}$, yellowish-brown sandy loam; 17-20 cm+, strong brown clay

ST $422 \quad 0-23 \mathrm{~cm}$, yellowish-brown sandy loam; 23-26 cm+, strong brown clay

ST 423 0-10 cm, very dark grayish-brown sandy loam; 10-13 cm+, red clay

ST $424 \quad 0-5 \mathrm{~cm}$, dark grayish-brown sandy loam; 5-28 cm, yellowish-brown sandy loam; $28-30 \mathrm{~cm}+$, strong brown clay

ST $425 \quad 0-18 \mathrm{~cm}$, yellowish-brown sandy loam; 18-20 cm+, strong brown clay

ST 426 0-12 cm, dark grayish-brown sandy loam; 12-14 cm+, red clay

ST 427 0-10 cm, dark grayish-brown sandy loam; 10-23 cm, yellowish-brown sandy loam; 23-26 cm+, strong brown clay

ST 428 0-10 cm, dark grayish-brown sandy loam; 10-34 cm, yellowish-brown sandy loam; 34-36 cm+, strong brown clay

ST $429 \quad 0-20 \mathrm{~cm}$, yellowish-brown sandy loam; $20-22 \mathrm{~cm}+$, strong brown clay

ST $430 \quad 0-31 \mathrm{~cm}$, strong brown and gray loam fill; 31-52 cm, yellowish-brown sandy loam; 52-54 cm+, strong brown clay

ST $431 \quad 0-5 \mathrm{~cm}$, dark grayish-brown sandy loam; 5-15 cm+, strong brown clay 
Appendix 3.

Map of Site Locations at Martin Creek Lake State Park.

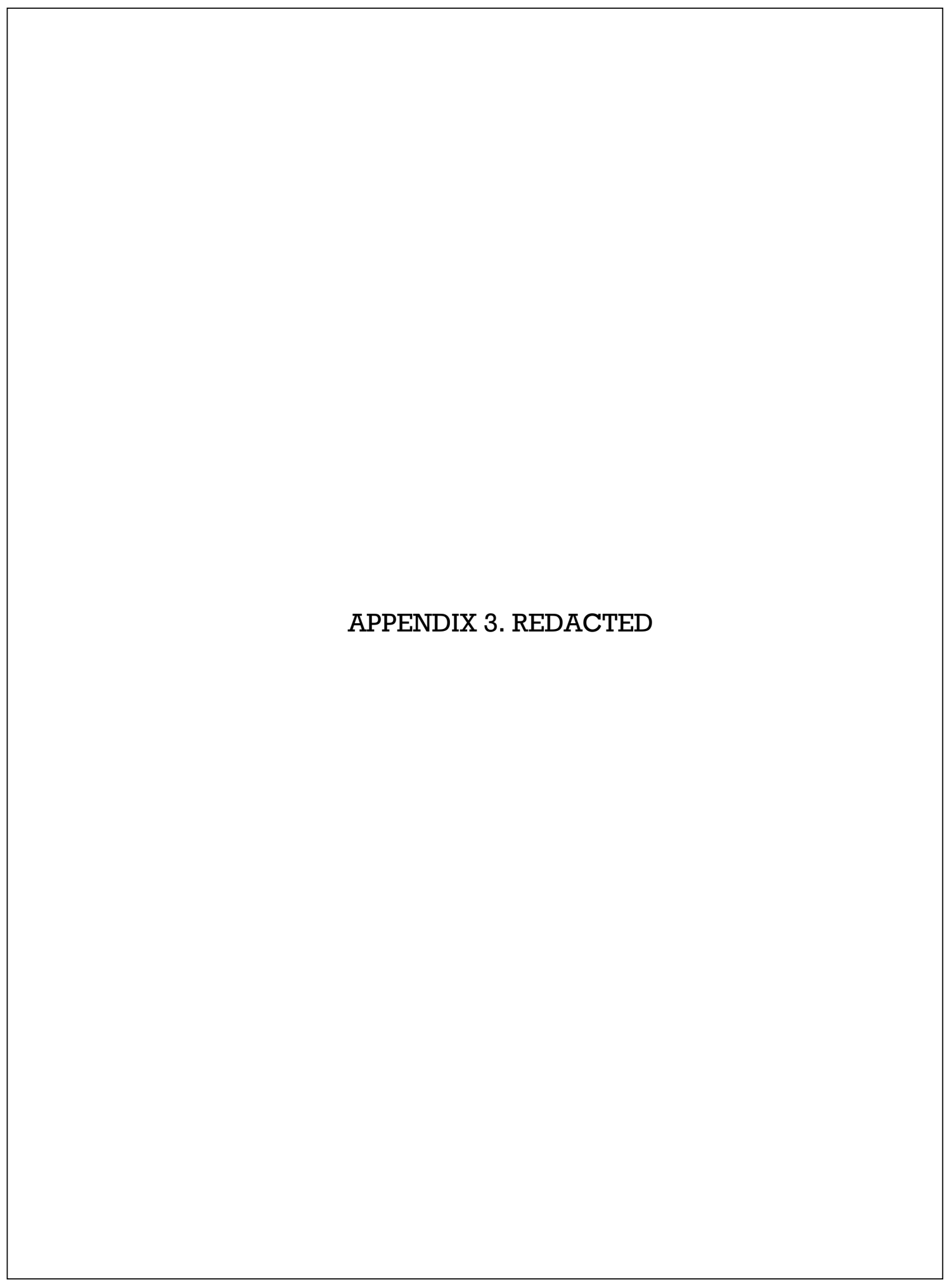




\section{Appendix 4.}

\section{Inventory of Artifacts from the 2010 Martin Creek Lake State Park Archeological Survey}

\section{RK66}

ST $130,0-20 \mathrm{~cm}$

ST $134,0-20 \mathrm{~cm}$

ST $137,0-20 \mathrm{~cm}$

ST $141,0-20 \mathrm{~cm}$

ST $178,0-20 \mathrm{~cm}$

ST $180,0-20 \mathrm{~cm}$

ST $182,0-20 \mathrm{~cm}$

Unit 387, 0-10 cm

Unit 387, 10-20 cm

Unit $387,30-35 \mathrm{~cm}$

\section{RK69}

ST 308, 0-17 cm

ST $318,0-20 \mathrm{~cm}$

ST 319, 0-17 cm

ST $321,0-20 \mathrm{~cm}$

ST $331,0-20 \mathrm{~cm}$

ST $333,0-12 \mathrm{~cm}$

Unit 390, 0-10 cm

Unit 393, 0-10 cm
1 clear bottle glass sherd

1 white milk glass sherd, probable cosmetics container

1 fruit jar zinc lid and white milk glass lid liner sherds $(n=6)$

1 clear window glass sherd

1 hand-made brick fragment; 9 clear bottle glass sherds; 1 clear bottle glass lip sherd; 1 clear bottle glass base sherd

1 clear bottle glass base sherd

l cut nail; 1 aqua window glass sherd; 1 plain whiteware rim sherd

1 hand-made brick fragment; 1 plain whiteware body sherd; 1 salt glazed-stoneware sherd

1 brown bottle glass sherd; 1 plain whiteware body sherd

1 cut nail

1 amber glass sherd

9 cast iron stove fragments; 2 cut nails; 1 iron rod and bolt/washer

1 iron hook; 1 iron wheel (38 mm in diameter) and attached iron leg; 1 hand-made brick fragment; 1 plain ironstone rim sherd; 1 cut nail

1 unidentifiable nail shank; 1 brown bottle glass sherd; 1 brown stoneware sherd

1 amber bottle glass sherd; 1 cut/forged nail; 1 cut nail

1 wire nail; 1 cut nail; 1 plain whiteware body sherd

4 brown bottle glass sherds; 3 clear bottle glass sherds; 1 plain whiteware body sherd; 5 cut nails

1 amber bottle glass sherd; 1 hand-made brick fragment; 1 clear bottle glass vial sherd; 1 aqua bottle glass sherd; 4 unidentifiable nail shanks; 3 cut nails 
2 plain porcelain sherds; 1 white milk glass sherd; 2 plain whiteware sherds; 1 handmade brick fragment; 1 machine-made brick fragment; 1 yellow glass base sherd; 2 porcelain buttons; 2 cut nails; 2 unidentifiable nail shanks

\section{RK71}

ST $373,0-20 \mathrm{~cm}$

ST $373,20-40 \mathrm{~cm}$

ST $375,0-20 \mathrm{~cm}$

ST $376,0-20 \mathrm{~cm}$

ST $379,0-20 \mathrm{~cm}$

ST $381,20-40 \mathrm{~cm}$

Unit $382,0-10 \mathrm{~cm}$

Unit 382, 10-20 cm

Unit $382,20-30 \mathrm{~cm}$
5 metal can fragments

7 metal can fragments

1 wire nail

2 wire nails; 1 plain whiteware rim sherd

1 wire nail

1 aqua window glass sherd

1 clear bottle glass sherd; 1 wire nail

3 possible metal can fragments; 1 wire nail; 1 thin blue-green glass sherd; 1 clear bottle glass sherd; 1 unidentifiable cupreous fragment

1 unidentified iron fragment

\section{RI467}

ST $2,0-20 \mathrm{~cm}$

ST $2,20-40 \mathrm{~cm}$

ST 6, 0-20 cm

ST $6,20-40 \mathrm{~cm}$

ST 8, 0-20 cm

ST $8,20-40 \mathrm{~cm}$

ST 9, 0-20 cm

ST $9,20-40 \mathrm{~cm}$

ST $10,20-40 \mathrm{~cm}$

Unit $391,0-10 \mathrm{~cm}$
1 unidentifiable nail shank; 1 green bottle glass sherd; 1 clear fruit jar glass sherd; 1 aqua tableware sherd; 1 clear bottle glass sherd; 2 aqua window glass sherds

4 clear bottle glass sherds; 1 bright green bottle glass sherd; 1 petrified wood dart point stem fragment

1 aqua window glass sherd

1 clear fruit jar lip sherd

5 asphalt shingle fragments; 1 battery rod; 1 hard rubber button; 2 unidentifiable metal fragments; 6 clear bottle glass sherds; 1 clear fruit jar glass lip sherd; 1 clear tableware glass sherd

6 clear bottle glass sherds; 1 unidentifiable metal fragment

1 clear bottle glass sherd

1 clear bottle glass sherd

1 bright green fruit jar glass base sherd; 1 aqua window glass sherd

2 white milk glass lid liner sherds; 1 hand-made brick fragment; 8 pieces of asphalt shingle; 1 unidentifiable nail shank; 2 unidentifiable iron fragments; 38 clear bottle glass sherds; 1 aqua bottle glass sherd; 4 clear window glass sherds; 5 clear fruit jar glass sherds 
Unit 391, 10-20 cm 1 battery rod; 5 pieces of asphalt shingle; 1 white milk glass lid liner sherd; 4 unidentifiable nail shanks; 5 unidentifiable metal fragments; 1 thin iron sheet fragment; 17 clear bottle glass sherds; 3 clear window glass sherds

Unit 391, 20-30 cm 1 hand-made brick fragment; 1 unidentified nail fragment; 1 amber bottle glass sherd; 1 clear tableware glass sherd; 18 clear bottle glass sherds; 2 clear window glass sherds

\section{Site \#1 (41RK605)}

ST $12,80-100 \mathrm{~cm} \quad 1$ petrified wood lithic debris, non-cortical

ST $34,20-40 \mathrm{~cm} \quad 1$ chert lithic debris, non-cortical

\section{Site \#2 (41RK606)}

ST 97, 0-20 cm 1 hand-made brick fragment

ST 102, 0-20 cm 1 purple bottle glass sherd

ST 106, 0-20 cm 1 plain ironstone body sherd

ST $108,0-15 \mathrm{~cm} \quad 1$ aqua bottle glass sherd

ST 109, 0-20 cm 2 hand-made brick fragments

ST $111,0-20 \mathrm{~cm} \quad 1$ hand-made brick fragment; 2 clear bottle glass sherds

ST $11,20-40 \mathrm{~cm} \quad 1$ quartzite lithic debris, non-cortical

Unit 389, 0-10 cm 1 unidentifiable nail shank; 1 hand-made brick fragment; 1 plain whiteware body sherd

Unit $389,10-20 \mathrm{~cm} \quad 1$ aqua window glass sherd; 1 clear bottle glass sherd

Unit 389, 20-30 cm 1 blue bottle glass sherd; 1 plain whiteware body sherd; 1 thick clear glass sherd; 1 plain ironstone rim sherd

\section{Site \#3 (41RK607)}

ST $158,0-20 \mathrm{~cm}$

ST $158,20-40 \mathrm{~cm}$

ST $159,20-40 \mathrm{~cm}$

ST $161,0-20 \mathrm{~cm}$

ST $161,20-40 \mathrm{~cm}$
1 wire nail; 1 hand-painted-annular whiteware rim sherd

3 unidentifiable metal fragments; 1 aqua bottle glass sherd; 1 dark olive green bottle glass sherd

1 unidentifiable metal fragment; 2 olive green bottle glass sherds

1 cut nail; 1 aqua bottle glass sherd

1 cut nail 
ST $164,0-20 \mathrm{~cm} \quad 1$ plain whiteware body sherd

Unit 388, 0-10 cm 2 hand-made brick fragments; 2 clear bottle glass sherds; 1 porcelain button; 1 handpainted whiteware body sherd

Unit 388, 10-20 cm 1 unidentifiable nail shank; 1 hand-made brick fragment

Unit 388, 20-30 cm 1 cut nail; 1 red chert Scallorn arrow point

Unit $388,30-40 \mathrm{~cm} \quad 1$ aqua bottle glass sherd; 1 unidentifiable nail shank

\section{Isolated Find \#1}

ST $229,20-40 \mathrm{~cm} \quad 1$ chert lithic debris, non-cortical 

This report has been produced under contract with

Texas Parks and Wildlife Department

4200 Smith School Road

Austin, Texas 78744

www.tpwd.state.tx.us

TPWD Report No. PWD RP P4508-0111H (8/11)

In accordance with Texas State Depository Law, this publication is available at the Texas State Publications Clearinghouse and/or Texas Depository Libraries.

TPWD receives federal assistance from the U.S. Fish and Wildlife Service and other federal agencies and is subject to Title VI of the Civil Rights Act of 1964, Section 504 of the Rehabilitation Act of 1973, Title II of the Americans with Disabilities Act of 1990, the Age Discrimination Act of 1975, Title IX of the Education Amendments of 1972, and state anti-discrimination laws which prohibit discrimination the basis of race, color, national origin, age, sex or disability. If you believe that you have been discriminated against in any TPWD program, activity or facility, or need more information, please contact Civil Rights Coordinator for Public Access, U.S. Fish and Wildlife Service, 4401 N. Fairfax Drive, Mail Stop: MBSP-4020, Arlington, VA 22203. 


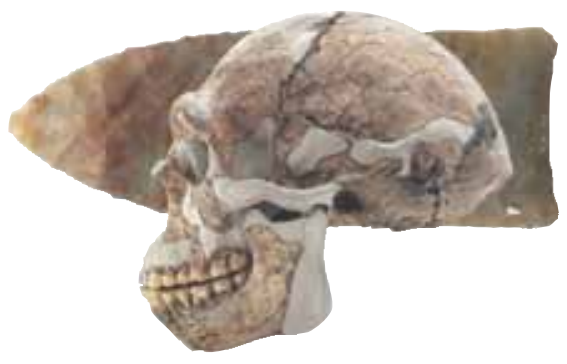

Center for Archaeological Studies

Texas State University-San Marcos

601 University Drive

San Marcos, TX 78666

www.txstate.edu/anthropology/cas/

\section{TEXAS $*$ STATE}

UNIVERSITY

SAN MARCOS

The rising STAR of Texas

A member of The Texas State University System 